ENVIRONMENTAL

RESTORATION

PROGRAM
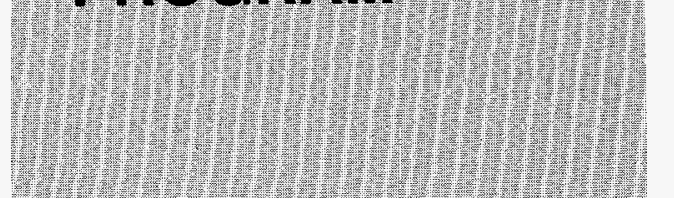

WIIt)
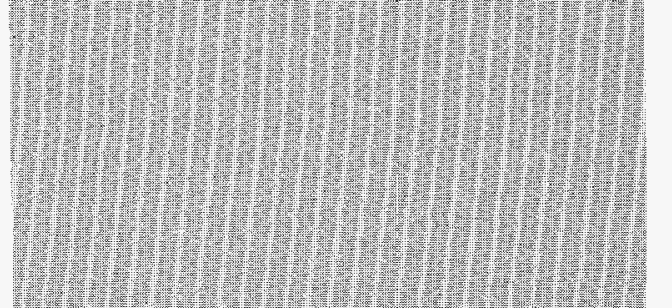

ग). W.

(1)

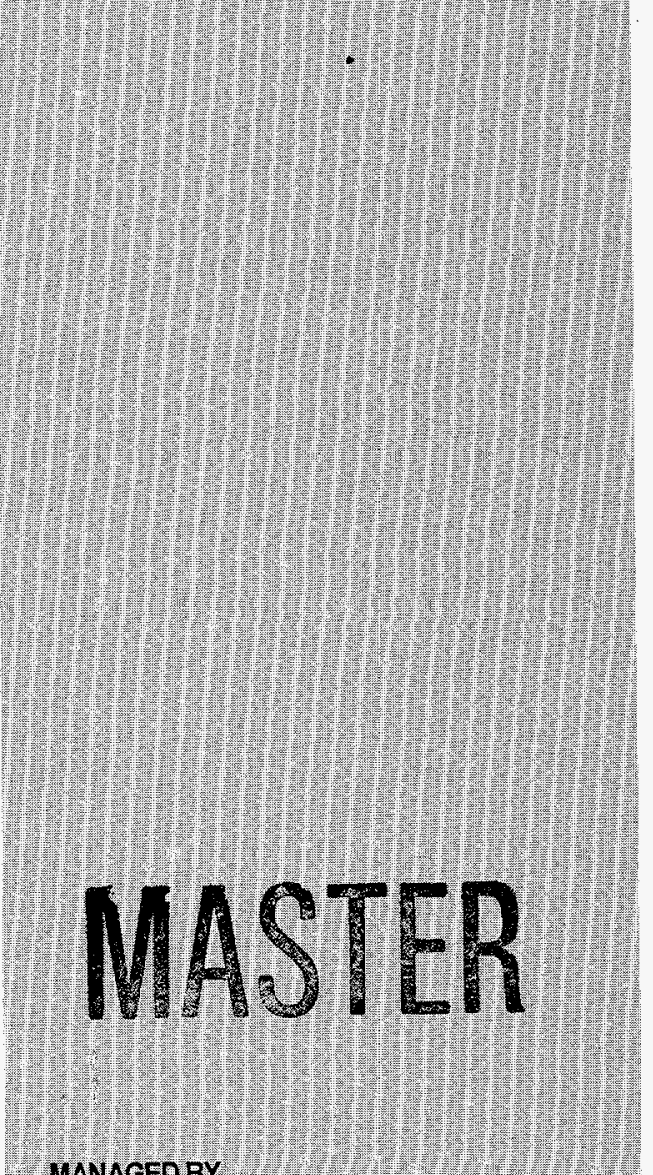

MANAGEDBY

LOCKHEED MARTIN ENERGY SYSTEMS, INC.

FOR THE UNITED STATES

DEPARTMENT OF ENERGY

\section{Mercury Abatement Report on the U.S. Department of Energy's Oak Ridge Y-12 Plant for Fiscal Year 1996}

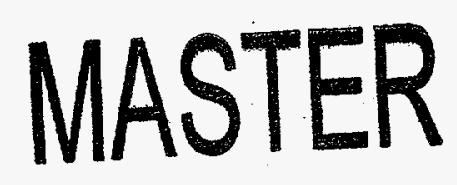

This document has been approved by the Y-12 Plant Technical Information Office for release to the public. Date: $11 / 13 / 96$

ENERGY SYSTEMS

DISTRIBUTION OF THIS DOCUMENT IS UNLAMTED

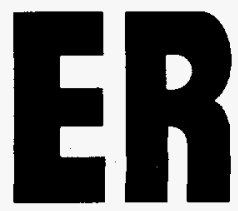


Energy Systems Environmental Restoration Program

\author{
Mercury Abatement Report \\ on the U.S. Department of Energy's \\ Oak Ridge Y-12 Plant for Fiscal Year 1996
}

Date Issued-November 1996

\author{
Prepared for the \\ U.S. Department of Energy \\ Office of Environmental Management \\ under budget and reporting code EW 20 \\ Environmental Management Activities at the \\ OAK RIDGE Y-12 PLANT \\ Oak Ridge, Tennessee 37831-8169 \\ managed by \\ LOCKHEED MARTIN ENERGY SYSTEMS, INC. \\ for the \\ U.S. DEPARTMENT OF ENERGY \\ under contract DE-AC05-84OR21400
}





\section{PREFACE}

This report was prepared in accordance with the requirements under the National Pollutant Discharge Elimination System (NPDES) permit (TN0002968) issued April 28, 1995 to the Y-12 Plant. This work was performed under work breakdown structure 1.4.12.1.1.03.44 (activity data sheet 2303, "Upper East Fork Poplar Creek"). This permit requires annual reporting of activities and progress towards achieving compliance goals agreed to between the U.S. Department of Energy and the State of Tennessee related to mercury releases into Upper East Fork Poplar Creek. Publication of this document in the October Discharge Monitoring Report on November 20,1996, meets an annual milestone in the Y-12 NPDES Permit. The document compares scheduled and actual completion dates for several corrective actions, summarizes results of characterization efforts that both identified mercury sources for elimination and demonstrated achievement of source eliminations, and outlines the nature and schedules for future corrective actions and monitoring. 



\section{DISCLAIMER}

This report was prepared as an account of work sponsored by an agency of the United States Government. Neither the United States Government nor any agency thereof, nor any of their employees, makes any warranty, express or implied, or assumes any legal liability or responsibility for the accuracy, completeness, or usefulness of any information, apparatus, product, or process disclosed, or represents that its use would not infringe privately owned rights. Reference herein to any specific commercial product, process, or service by trade name, trademark, manufacturer, or otherwise does not necessarily constitute or imply its endorsement, recom. mendation, or favoring by the United States Government or any agency thereof. The views and opinions of authors expressed herein do not necessarily state or reflect those of the United States Government or any agency thereof. 


\section{DISCLAMMER}

Portions of this document may be illegible in electronic image products. Images are produced from the best available original document. 


\section{CONTENTS}

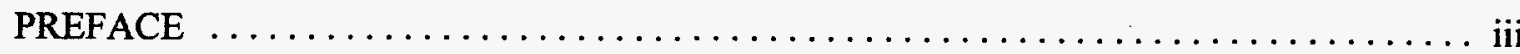

FIGURES $\ldots \ldots \ldots \ldots \ldots \ldots \ldots \ldots \ldots \ldots \ldots \ldots \ldots \ldots \ldots \ldots \ldots \ldots \ldots \ldots \ldots$

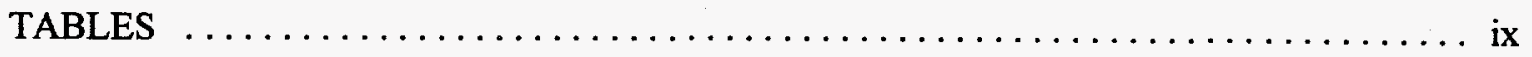

ABBREVIATIONS $\ldots \ldots \ldots \ldots \ldots \ldots \ldots \ldots \ldots \ldots \ldots \ldots \ldots \ldots \ldots \ldots \ldots \ldots \ldots \ldots$

EXECUTIVE SUMMARY $\ldots \ldots \ldots \ldots \ldots \ldots \ldots \ldots \ldots \ldots \ldots \ldots \ldots \ldots \ldots \ldots \ldots \ldots$ xiii

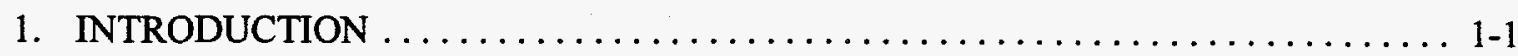

2. DESIGN AND CONSTRUCTION PROJECT SUMMARY $\ldots \ldots \ldots \ldots \ldots \ldots \ldots \ldots 2-1$

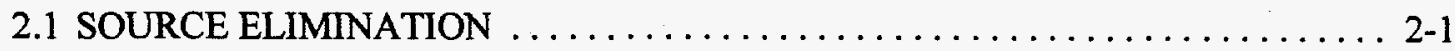

2.2 EAST END MERCURY TREATMENT SYSTEM

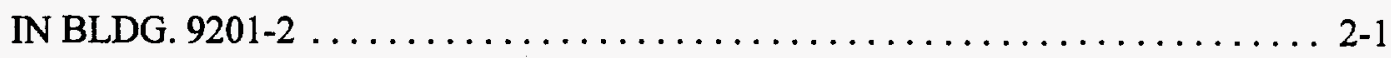

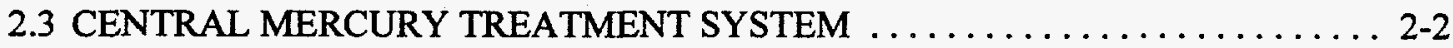

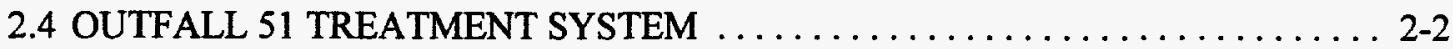

2.4.1 Mercury Air Stripping Test Facility at Outfall $51 \ldots \ldots \ldots \ldots \ldots \ldots . \ldots \ldots 2-2$

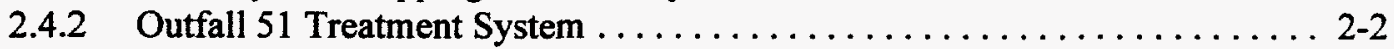

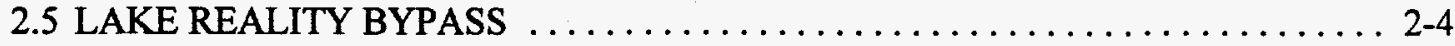

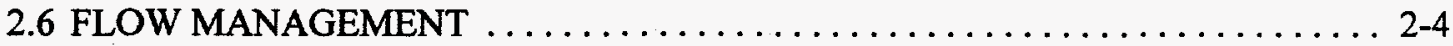

3. CHARACTERIZATION OF MERCURY SOURCES $\ldots \ldots \ldots \ldots \ldots \ldots \ldots \ldots \ldots \ldots \ldots \ldots$

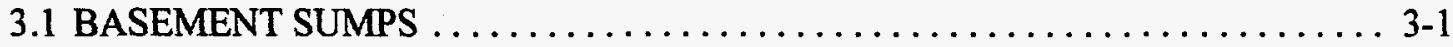

3.2 OUTFALLS AND OTHER SURFACE WATER

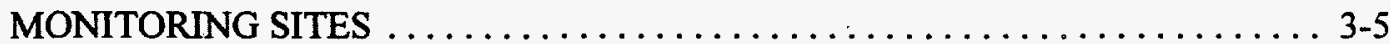

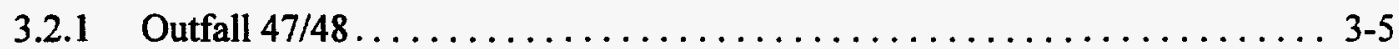

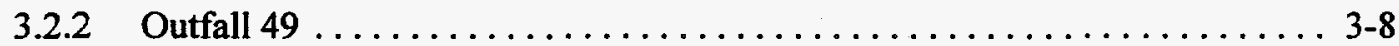

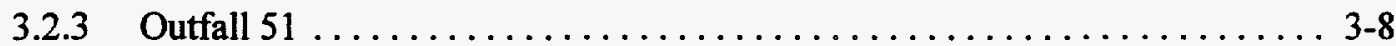

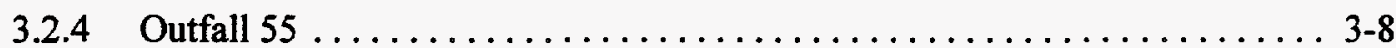

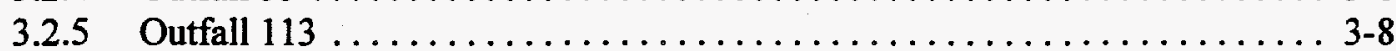

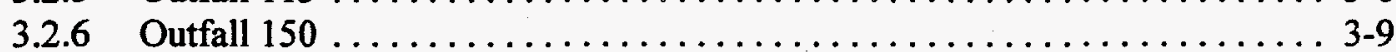

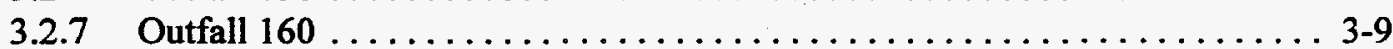

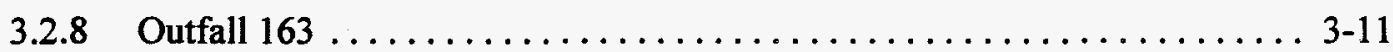

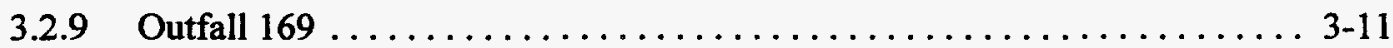

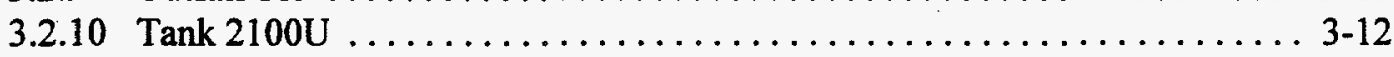

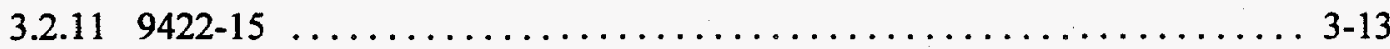

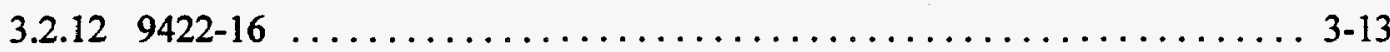

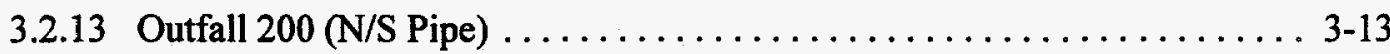

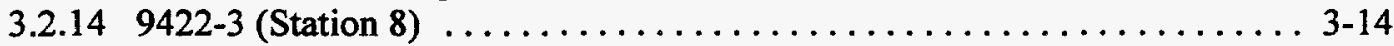

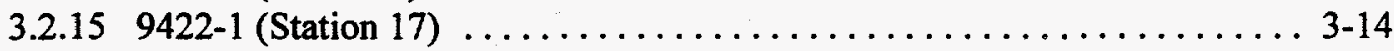

3.2.16 Catch Basins Upstream of Outfalls 163 and $169 \ldots \ldots \ldots \ldots \ldots \ldots$ 3-19 
3.3 MODELING OF THE HYDROLOGIC TRANSPORT OF MERCURY

IN THE UEFPC WATERSHED $\ldots \ldots \ldots \ldots \ldots \ldots \ldots \ldots \ldots \ldots \ldots \ldots, 3-21$

3.4 EVALUATION OF STREAMBED SEDIMENTS $\ldots \ldots \ldots \ldots \ldots \ldots \ldots \ldots, 3-22$

4. LONGITUDINAL DISTRIBUTION OF MERCURY AND MERCURY

SPECIATION IN EAST FORK POPLAR CREEK

5. BIOLOGICAL MONITORING AND ABATEMENT PROGRAM

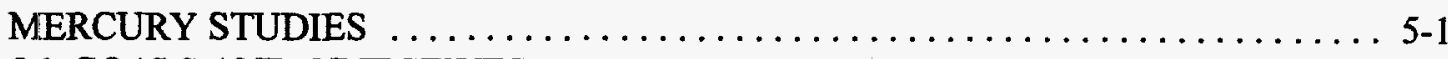

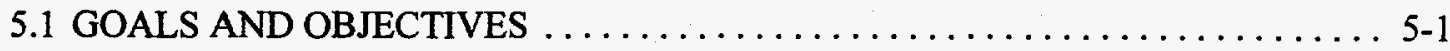

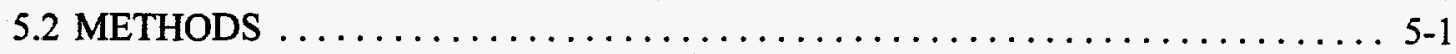

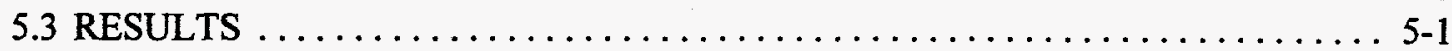

5.3.1 Downstream Profiles of Mercury Contamination $\ldots \ldots \ldots \ldots \ldots \ldots \ldots$. 5-1

5.3.2 Changes in Mercury Bioaccumulation over Time $\ldots \ldots \ldots \ldots \ldots \ldots \ldots, 5-5$

5.3.3 Mercury Concentrations and Speciation in Forage Fish ........... 5-5

5.3.4 Relationship Between Concentrations of Total Mercury in

Water and Bioaccumulation of Mercury in Fish . . . . . . . . . . . . . . .

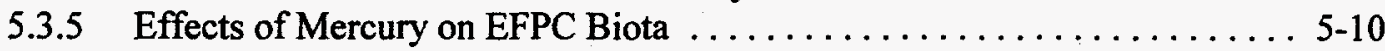

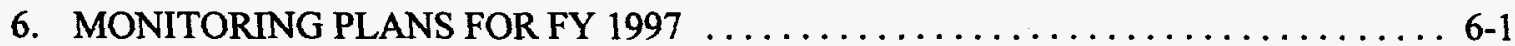

6.1 MONTHLY PROGRAM $\ldots \ldots \ldots \ldots \ldots \ldots \ldots \ldots \ldots \ldots \ldots, 6,2$

6.2 QUARTERLY PROGRAM $\ldots \ldots \ldots \ldots \ldots \ldots \ldots \ldots \ldots \ldots \ldots \ldots \ldots, 6,2$

6.3 STORMWATER PROGRAM $\ldots \ldots \ldots \ldots \ldots \ldots \ldots \ldots \ldots \ldots \ldots \ldots \ldots \ldots, 6,3$

6.3.1 Stormwater Screening Study $\ldots \ldots \ldots \ldots \ldots \ldots \ldots \ldots \ldots \ldots \ldots \ldots \ldots, 6,3$

6.4 LONGITUDINAL PROGRAM $\ldots \ldots \ldots \ldots \ldots \ldots \ldots \ldots \ldots \ldots \ldots \ldots \ldots \ldots, 6,4$

7. SUMMARY OF CURRENT CONDITIONS AND CONCLUSIONS $\ldots \ldots \ldots \ldots \ldots 7-1$

APPENDIX A Results of Monthly Grab Sampling Program for Fiscal Year 1996 . . . . . . A-1

APPENDIX B Results of Quarterly Composite Sampling Program for Fiscal Year 1996 . . B B-1

APPENDIX C Weekly Mercury Results for Outfall 51 During Fiscal Year $1996 \ldots \ldots \ldots$ C-1

APPENDIX D Bi-weekly Mercury Results and Daily Flows

for Outfall 55 During Fiscal Year 1996.

D-1 


\section{FIGURES}

2.1 Mercury removal efficiency of air stripper versus air flow rate $\ldots \ldots \ldots \ldots \ldots 2 \div 3$

2.2 Removal of mercury from Outfall 51 by air stripping following stannous chloride addition versus molar ratio of concentration of tin to total mercury $\ldots \ldots 2-3$

3.1 Schematic of buildings, sumps, drain lines, outfalls, and surface water monitoring locations relevant to the Y-12 Plant's mercury

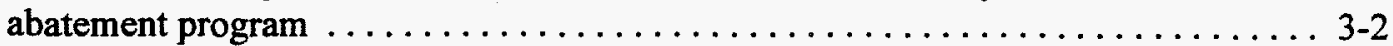

3.2 Average dry weather flow, mercury concentration, mercury loading, and percent of total mercury loading for outfalls sampled four or more times between July

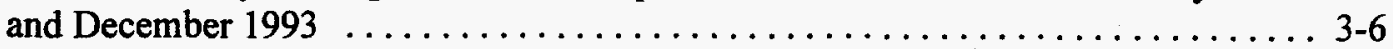

3.3 Average dry weather flow, mercury concentration, mercury loading, and percent of total mercury loading for Y-12 outfalls during FY $1996 \ldots \ldots \ldots \ldots \ldots \ldots$ 3-7

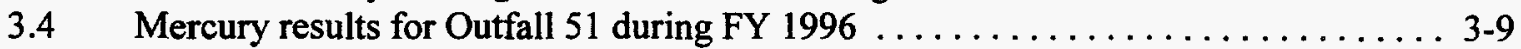

3.5 Temporal trend in mercury concentrations measured in Outfall 55 through

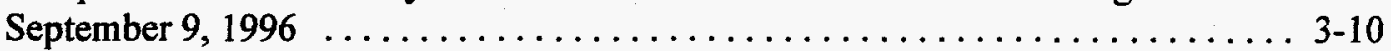

3.6 Daily mercury loadings for Station 8 (9422-3) for 1995

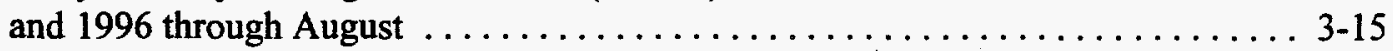

3.7 Running 3-month average mercury loadings (grams/day) at Station 8 (9422-3) for all flows and for flows greater than 7, 10, 12, and 15 MGD

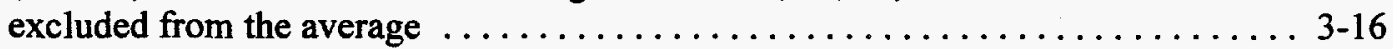

3.8 Monthly average mercury concentration at Station 17 from January 1989

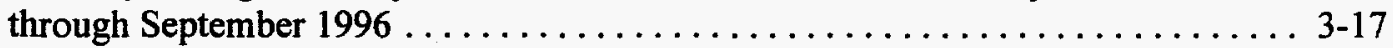

3.9 Running 3-month average mercury loading (grams/day) at Station 17 (9422-1) for all flows and for flows greater than 7 (or 8), 10, 12, and 15 MGD excluded

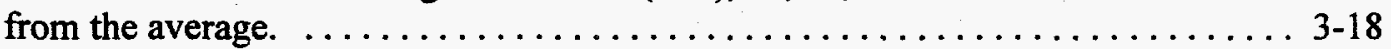

3.10 Schematic of catch basins and storm drains upstream of Outfalls 160 and $163 \ldots 3-20$

3.11 Schematic of catch basins and storm drains upstream of Outfall $169 \ldots \ldots \ldots . .3-21$

3.12 Variation of mercury concentration with sediment particle size class at the upper end of Upper East Fork Poplar Creek natural channel . . . . . . . . . . . . . 3-23

3.13 Variation of bulk mercury concentration for sand/silt/clay classes in UEFPC

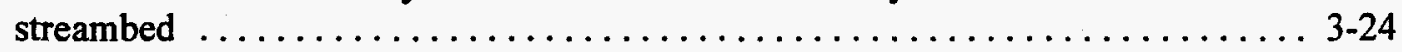

4.1 Results of longitudinal sampling and analysis of water for total and dissolved mercury and methylmercury from East Fork Poplar Creek in November 1995 . . . . 4-4

4.2 Results of longitudinal sampling and analysis of water for total and dissolved mercury and methylmercury from East Fork Poplar Creek in May 1996 . . . . . . 4 4-5

4.3 Results of longitudinal sampling and analysis of water for total and dissolved mercury and methylmercury from East Fork Poplar Creek in September 1996 . . . 4 4-6

5.1 Sampling sites for redbreast sunfish in East Fork Poplar Creek

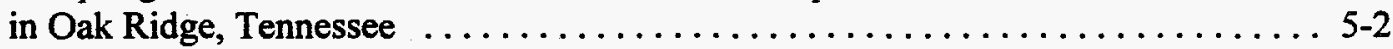

5.2 Mean concentration of mercury in redbreast sunfish ( $n=8$ fish per site) in East Fork Poplar Creek versus distance upstream from its mouth $\ldots \ldots \ldots \ldots \ldots \ldots \ldots$ 5-4

5.3 Mean concentration of mercury in redbreast sunfish ( $n=64$ fish per site) in East Fork Poplar Creek versus distance upstream from its mouth, prior to Lake Reality . . . . 5 5-5

5.4 Average mercury concentration in redbreast sunfish fillets, East Fork Poplar Creek

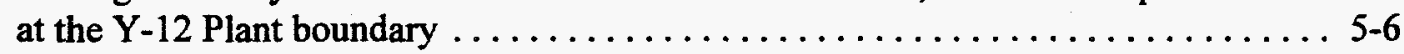


5.5 Average mercury concentration in redbreast sunfish fillets, East Fork Poplar Creek,

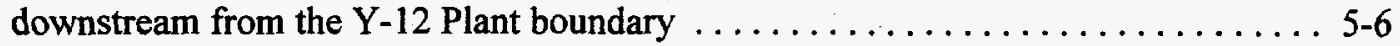

5.6 Increase in mean mercury concentration in redbreast sunfish at sites in lower East Fork Poplar Creek.

5.7 Mercury in water and fish in East Fork Poplar Creek at the Y-12 Plant boundary since Lake Reality was completed

5.8 Mean concentration of total mercury in composite samples $(n=3)$ of forage fish [stonerollers (Campostoma anomalum) and striped shiners (Luxilus chrysocephalus)] from sites in East Fork Poplar Creek

5.9 Mean concentration of methylmercury in composite samples $(n=3)$ of forage fish [stonerollers (Campostoma anomalum) and striped shiners (Luxilus chrysocephalus)] from sites in East Fork Poplar Creek

5.10 Relationship between total mercury in sunfish fillets and total mercury in water in selected mercury-contaminated hardwater streams and reference streams . . . . 5 5-10

5.11 Increase in fish population density in Upper East Fork Poplar Creek, 1985-1995 . . 5-11 


\section{TABLES}

2.1 Status of mercury treatment and remediation activities $\ldots \ldots \ldots \ldots \ldots \ldots \ldots \ldots$

3.1 Key Y-12 Plant mercury monitoring locations for FY 1996 and beyond ....... 3-3

3.2 Results of sump water sampling in Bldgs. 9201-4, 9201-5 and 9204-4

and estimates of loading based on flow before and after pipe reroutes . . . . . . 3-4

3.3 Mercury results from comparison study of composite samplers at Station 17 . . . 3-19

4.1 Results of longitudinal sampling of EFPC conducted November 27, $1995 \ldots \ldots$. . 4-2

4.2 Results of longitudinal sampling of EFPC conducted May 31, $1996 \ldots \ldots \ldots .4$

4.3 Results of longitudinal sampling of EFPC conducted September 10, 1996 ... . . 4-7

5.1 Concentrations of mercury (mean $\pm \mathrm{SE}, \mathrm{mg} / \mathrm{kg}$ wet wt.) in fillets of redbreast

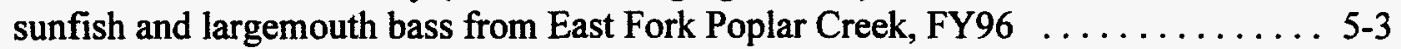

6.1 Key Y-12 Plant mercury monitoring locations for FY $1997 \ldots \ldots \ldots \ldots \ldots \ldots$. . . . . 



\section{ABBREVIATIONS}

\begin{tabular}{|c|c|}
\hline BCK & Bear Creek kilometer \\
\hline BMAP & Biological Monitoring and Abatement Program \\
\hline BMP & best management practice \\
\hline CERCLA & Comprehensive Environmental Response, Compensation, and Liability Act \\
\hline CMTS & Central Mercury Treatment System \\
\hline DOE & U.S. Department of Energy \\
\hline EEMTS & East End Mercury Treatment System \\
\hline EFK & East Fork Poplar Creek kilometer \\
\hline EFPC & East Fork Poplar Creek \\
\hline EMD & Environmental Management Department \\
\hline ER & Environmental Restoration Program \\
\hline ESD & Environmental Sciences Division \\
\hline $\mathrm{FY}^{\prime}$ & fiscal year \\
\hline g/day & grams per day \\
\hline gal/day & gallons per day \\
\hline $\mathrm{g} / \mathrm{L}$ & grams per liter \\
\hline gpm & gallons per minute \\
\hline $\mathrm{Hg}$ & mercury \\
\hline IHgTU & Interim Mercury Treatment Unit \\
\hline LRL & lower reporting limit \\
\hline MGD & million gallons per day \\
\hline $\mathrm{mg} / \mathrm{kg}$ & milligrams per kilogram \\
\hline $\mathrm{mg} / \mathrm{L}$ & milligrams per liter \\
\hline $\mathrm{mm}$ & millimeter \\
\hline $\mathrm{ng} / \mathrm{L}$ & nanograms per liter \\
\hline NOAA & National Oceanic and Atmospheric Administration \\
\hline NPDES & National Pollutant Discharge Elimination System \\
\hline N/S Pipe & North/South Pipe \\
\hline ORNL & Oak Ridge National Laboratory \\
\hline ORR & Oak Ridge Reservation \\
\hline ppm & part per million \\
\hline RL-IN & Lake Reality Inlet \\
\hline RMPE & Reduction of Mercury in Plant Effluent \\
\hline TSS & total suspended solids \\
\hline UEFPC & Upper East Fork Poplar Creek \\
\hline Y-12 Plant & Oak Ridge Y-12 Plant \\
\hline$\mu \mathrm{g} / \mathrm{g}$ & micrograms per gram \\
\hline$\mu \mathrm{g} / \mathrm{L}$ & micrograms per liter \\
\hline$\mu \mathrm{m}$ & micrometer \\
\hline
\end{tabular}





\section{EXECUTIVE SUMMARY}

This report summarizes the status of activities and the levels of mercury contamination in Upper East Fork Poplar Creek (UEFPC) resulting from activities at the Department of Energy's (DOE's) Y-12 Facility during fiscal year 1996 (FY96). The report outlines the status of ongoing and new project activities in support of project goals, the results of sampling and characterization efforts conducted during FY 1996, biological monitoring activities, and our conclusions relative to the progress in demonstrating compliance with the National Pollutant Discharge Elimination (NPDES) permit.

Much progress has been made in the past few years towards the goal of reducing mercury releases to UEFPC to environmentally acceptable levels. As discussed in this report, the schedule for completion of corrective actions has been accelerated to provide an opportunity to identify and complete any additional actions necessary to meet the NPDES permit goal of $5 \mathrm{~g} /$ day by December 31 , 1998. In addition, certain recognized sources (e.g., Outfall 51 and recently the catch basin at E3250N) initially thought to be beyond cost-effective treatment have been aggressively investigated and promising treatment options pursued. Thus, corrective actions for these difficult sources will be implemented in the near future. In other cases (e.g., Outfall 47/48), corrective actions upstream (pipe reroutes/replacements) not directed at mercury reduction have attenuated $\mathrm{Hg}$ releases.

Mercury concentrations in sunfish in EFPC at the Y-12 Plant boundary continue to be considerably lower than in the mid-1980s. However, the absence of a downward temporal trend in mercury contamination in fish at the plant boundary continues to be disappointing. No change is apparent at this site or in the middle reaches of EFPC over the past few years. In early FY97, aqueous mercury concentrations are expected to experience substantially larger reductions than have occurred since Outfall 49 was eliminated and the mercury treatment facility in Bldg. 9201-2 became operational. This is due to operation of the CMTS and the bypass of Lake Reality. It is hoped that these reductions will eventually be manifested in decreasing mercury levels in fish.

There is a large reservoir of biologically incorporated methylmercury within, and upstream of, Lake Reality that must cycle through the system for decreases in mercury concentration in fish at the plant boundary and downstream to be evident. Time lags associated with cycling of residual methylmercury in fish might be reduced by active management of the fish population in EFPC above Lake Reality, with the separate goals of increasing species richness and reducing the inventory of biologically incorporated mercury. 


\section{INTRODUCTION}

This report summarizes the status of activities and the levels of mercury contamination in Upper East Fork Poplar Creek (UEFPC) resulting from activities at the Department of Energy's (DOE's) Y-12 Facility during fiscal year 1996 (FY96). The report outlines the status of ongoing and new project activities in support of project goals, the results of sampling and characterization efforts conducted during FY 1996, biological monitoring activities, and our conclusions relative to the progress in demonstrating compliance with the National Pollutant Discharge Elimination (NPDES) permit.

Although the pace of mercury remediation activities at DOE's Y-12 Plant is ahead of the compliance schedule established in the NPDES permit, the resulting level of mercury in UEFPC is higher than predicted based on the projects completed. Fortunately, recently recognized opportunities are being pursued for implementation in the next two years to assist in meeting permit requirements. 


\section{DESIGN AND CONSTRUCTION PROJECT SUMMARY}

As part of the plan for achieving compliance with the permit limits for mercury, several activities have been completed or are ongoing. These activities are discussed in the following sections.

\subsection{SOURCE ELIMINATION}

All of the source elimination projects are now complete. Table 2.1 gives the completion dates for source elimination as well as for other treatment and remediation activities. Evaluation of the effect of these projects on the mercury loading in East Fork Poplar Creek (EFPC) is ongoing.

Table 2.1 Status of mercury treatment and remediation activities

\begin{tabular}{ccc}
\hline Activity & $\begin{array}{c}\text { Compliance } \\
\text { completion date }\end{array}$ & $\begin{array}{c}\text { Actual/forecasted } \\
\text { completion date }\end{array}$ \\
\hline Source elimination - 9201-2 & $12 / 1 / 95$ & $7 / 30 / 94$ \\
Source elimination - 9201-5 & $6 / 1 / 96$ & $5 / 19 / 96$ \\
Source elimination - 9201-4 & $9 / 1 / 96$ & $10 / 20 / 95$ \\
Source elimination - 9204-4 & $1 / 1 / 97$ & $9 / 30 / 96$ \\
Central Mercury Treatment System & $1 / 1 / 98$ & $11 / 11 / 96$ \\
East End Treatment System & $1 / 1 / 98$ & $5 / 6 / 96$ \\
Outfall 51 treatment system* & NA & $7 / 31 / 98$ \\
Lake Reality bypass (temporary)* & NA & $11 / 8 / 96$ \\
\hline
\end{tabular}

${ }^{\star}$ Not included in the NPDES permit compliance schedule.

\subsection{EAST END MERCURY TREATMENT SYSTEM IN BLDG. 9201-2}

The East End Mercury Treatment System (EEMTS) in Bldg. 9201-2 began operation on May 6, 1996. EEMTS is an upgrade of the Interim Mercury Treatment Unit (IHgTU) to a permanent system with a capacity of 30 gal per minute (gpm). Treated water from the EEMTS is discharged through Outfall 550. Since the IHgTU (and now the EEMTS) began operation, approximately 9,400,000 gal of water have been treated with no exceedances of the mercury limits of $0.002 \mathrm{mg} / \mathrm{L}$ monthly average and $0.004 \mathrm{mg} / \mathrm{L}$ daily maximum. This project meets the NPDES requirement to have a permanent system in Bldg. $9201-2$ by January 1, 1998.

A project was planned to upgrade the EEMTS to a capacity of $60 \mathrm{gpm}$ to allow additional mercury contaminated water discharged through Outfall $47 / 48$ from Bldg. 9202 to be treated. However, a Y-12 Plant drain reroute project in Bldg. 9202 caused the discharge from Outfall 47/48 to be below mercury detection limits, and the project was put on hold. Sampling of Outfall 47/48 continues. If future reroutes in Bldg. 9202 cause the mercury levels to become a concern at Outfall $47 / 48$, the project will be restarted. 


\subsection{CENTRAL MERCURY TREATMENT SYSTEM}

The Central Mercury Treatment System (CMTS) has been installed in the Central Pollution Control Facility, Bldg. 9623, and will begin treating the sump waters from 9201-4, 9201-5, and 9204-4 in early November 1996. The CMTS consists of filters and carbon columns with a capacity of $50 \mathrm{gpm}$. The NPDES compliance date for this activity is January 1, 1998.

\subsection{OUTFALL 51 TREATMENT SYSTEM}

Outfall 51 is a mercury-contaminated natural spring that enters EFPC within the Y-12 Plant. Flow in the spring is typically 90 to $200 \mathrm{gpm}$, and mercury concentrations typically fall in the $2-6 \mu \mathrm{g} / \mathrm{L}$ range. A significant fraction (about $30 \%$ ) of the mercury is present as dissolved elemental mercury. Trace additions of the reductant stannous chloride were found to convert much of the remaining mercury (presumably labile $\mathrm{Hg}$ (II) complexes) to elemental mercury, resulting in most of the mercury being present in a highly volatile form. The feasibility of using air stripping to remove the volatile elemental mercury from water was investigated in a pilot scale (10 gpm) air stripper.

\subsubsection{Mercury Air Stripping Test Facility at Outfall 51}

The air stripper was highly effective at removing elemental mercury from Outfall 51 water, eliminating virtually $100 \%$ of the volatile mercury from input water at all but the lowest air/water ratios tested (Fig. 2.1). Laboratory studies demonstrated that adding stannous chloride resulted in making approximately $80 \%$ of the mercury in Outfall 51 water available for air stripping. Similar results were seen in field testing of the pilot plant, with a 3- to 4-fold stoichiometric excess of stannous tin to total mercury being adequate to reduce virtually all reactive mercury (Fig. 2.2).

Numerous treatments were investigated in the laboratory in attempts to convert the remaining nonvolatile mercury to a reducible form, including oxidants such as chlorine, permanganate, bromate, hydrogen peroxide, ultraviolet light, ozone, and methylene blue photosensitized oxidation in sunlight. None appeared capable of rapidly oxidizing mercury to a tin reducible form at environmentally acceptable oxidant concentrations.

Continuous operation of the pilot plant over a 2 -month period indicated that continuous operation was feasible with no decrease in removal efficiency. Biofouling did not interfere with flow of air or water through the unit and little day-to-day maintenance was required. Stannous chloride solutions in the feed reservoir were unstable in the presence of sunlight and oxygen, but this problem could be readily overcome by the use of concentrated $(>1 \mathrm{~g} / \mathrm{L})$ stannous chloride stock solution in oxygen-free water. An oxygen-free radical scavenger, ascorbic acid (vitamin $C$ ) proved to be an effective preservative of stannous chloride stock solutions. Passing the effluent air stream through an activated carbon bed removed all detectable elemental mercury from the air throughout the course of both short-term and continuous operation of the air stripper.

\subsubsection{Outfall 51 Treatment System}

A life cycle cost analysis comparing an air stripping system and a carbon system is being performed to determine the most cost-effective treatment for Outfall 51 . Design of the selected system is scheduled to begin in November 1996 with construction completed in July 1998. 


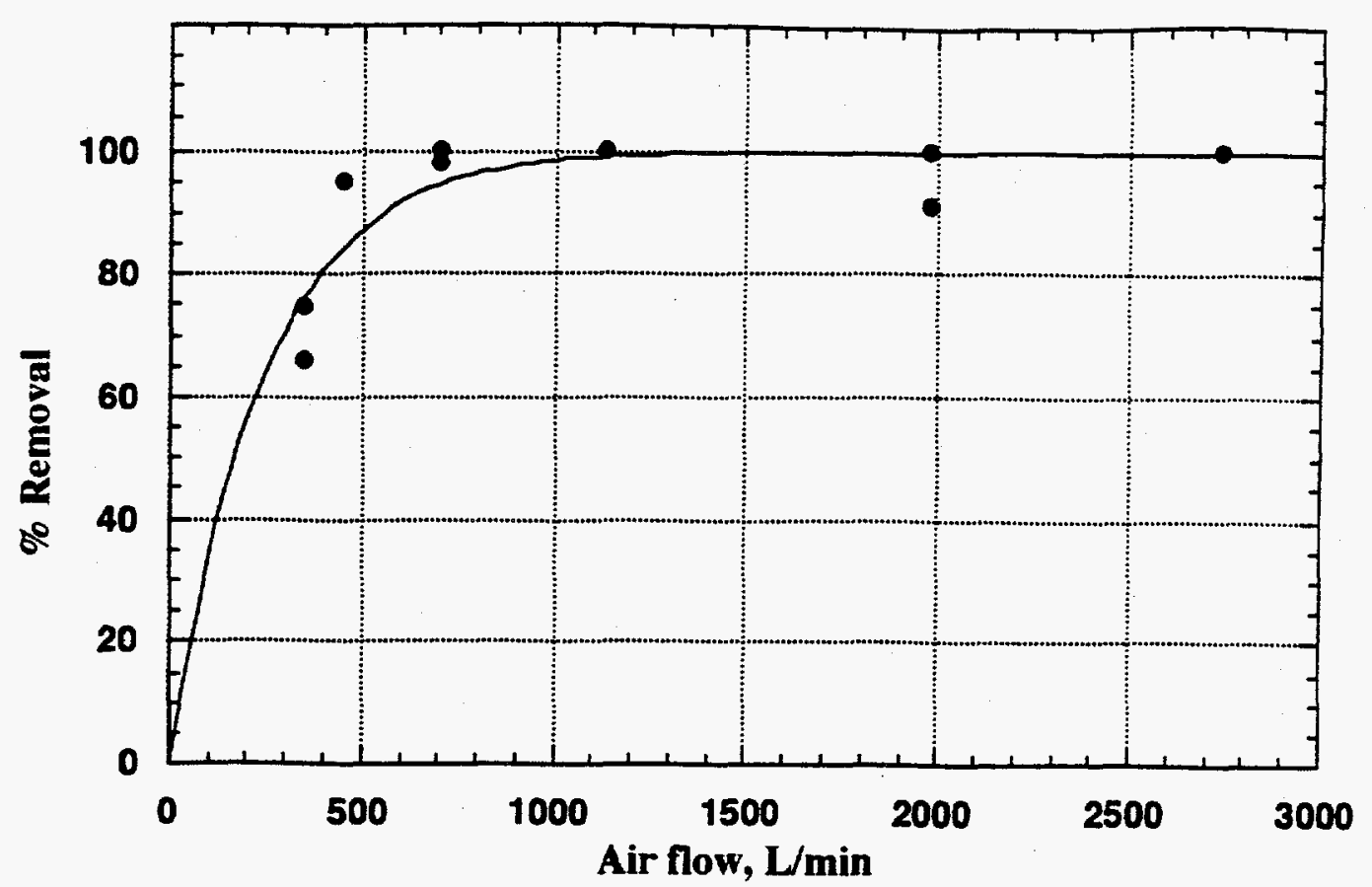

Fig. 2.1. Mercury removal efficiency of air stripper versus air flow rate. Conditions: water feed $=38 \mathrm{~L} / \mathrm{min}$, air temperature $12-23^{\circ} \mathrm{C}$.

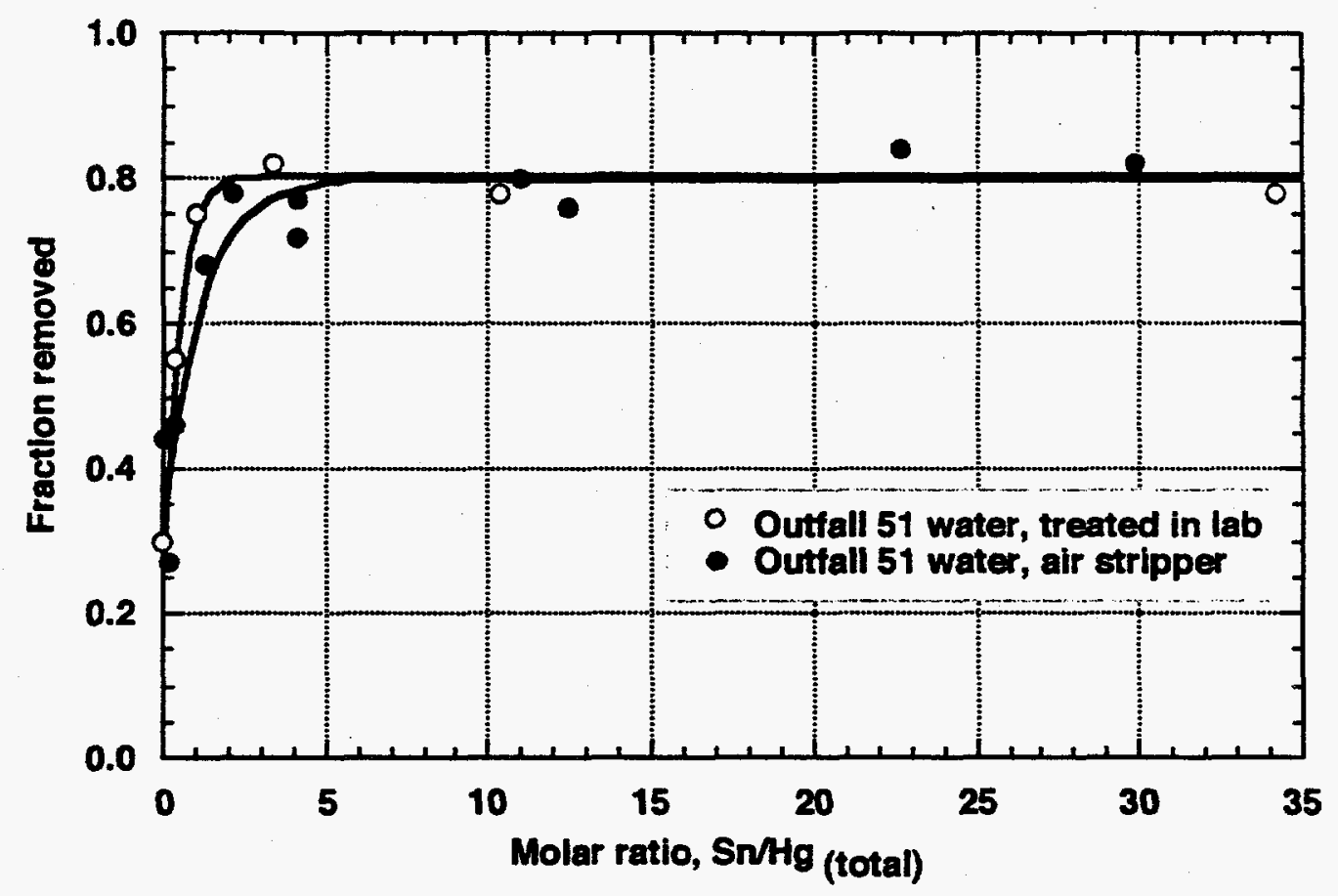

Fig. 2.2. Removal of mercury from Outfall 51 by air stripping following stannous chloride addition versus molar ratio of concentration of tin to total mercury. 


\subsection{LAKE REALITY BYPASS}

Lake Reality appears to have several adverse effects on mercury transport dynamics in EFPC. If the flow of UEFPC is routed around Lake Reality under baseflow conditions, but through the lake during storm flow, it is believed that the following beneficial changes in mercury transport will occur:

- Time averaged total mercury concentrations in EFPC downstream from Lake Reality will decrease mercury loading by about $5 \mathrm{~g}$ /day under baseflow;

- methylmercury input to the reach below Lake Reality will be reduced $80 \%$;

- $\quad$ sediment trapped in the lake during storm flow will not be subsequently released, thus total export of mercury to EFPC will be reduced; and

- methylmercury in fish now living in Lake Reality will be retained more effectively with reduced opportunities to emigrate.

A temporary bypass system is being installed at Lake Reality to evaluate its effects on the mercury transport dynamics. Lake Reality will be bypassed using a temporary siphon-based system for approximately 6 months. Under baseflow conditions, most of the UEFPC flow will be bypassed around the lake with a small flow maintained into the lake to retain its present level and adequate aquatic habitat. The bypass is scheduled to start operation in early November 1996. If the expected results are observed during the experimental phase, permanent bypass of the lake will be considered. Consideration will then also be given to a total baseflow and stormflow bypass, which would result in all aquatic life being removed from Lake Reality. Spill containment capability would be maintained.

\subsection{FL.OW MANAGEMENT}

The Flow Management Project, which began operation July 18, 1996, adds raw water flow from the Clinch River to EFPC just below Outfall 200. Starting at $0.2 \mathrm{M}$ gal/day (MGD), the flow was incrementally increased and has been at 4.5 MGD since August 19, 1996, except for a couple of flow interruptions. The additional flow is added to better meet the toxicity requirement at Outfall 201 and to restore flow to historical levels. In the 1970s and 1980s, flow at Station 17 equaled $\sim 8$ to $10 \mathrm{MGD}$ but now averages $\sim 3$ MGD due to decreasing plant operations. The NPDES permit requires a daily average of 7 MGD at Station 17 by March 1, 1997. 


\section{CHARACTERIZATION OF MERCURY SOURCES}

Point sources of mercury constitute almost all of the dry weather loading of mercury to UEFPC. These sources include (1) Hg-contaminated shallow groundwater, which is captured in basement sumps in several buildings and then pumped into the storm drain system; (2) Hg-contaminated natural spring flow into the creek via Outfall 51 ; and (3) $\mathrm{Hg}$-contaminated piping both internal and external to several buildings through which water (mainly cooling water and condensate) passes en route to the creek. Virtually all of these sources supply mercury to the creek via one or more recognized outfalls (Fig. 3.1). Intermittent characterization of $\mathrm{Hg}$ sources has been ongoing since 1982, with more comprehensive surveys conducted in the mid-1980s, 1990, and 1993-96.

The following Martin Marietta Energy Systems reports provide results from earlier characterization efforts through FY95: Sources and Discharges of Mercury in Drainage Waters at the Oak Ridge Y-12 Plant (Y/TS-90), Mercury Abatement at Y-12:A Progress Report (Y/ER-116), Site Characterization Summary Report for Dry Weather Surface Water Sampling, Upper East Fork Poplar Creek (Y/ER-229), and Mercury Abatement Report for Fiscal Year 1995 (Y/ER-251). During FY96, characterization efforts have been directed toward characterization of mercury loading from outfalls and key instream locations to provide information on the effectiveness of specific corrective actions to reduce or eliminate mercury loading and to define outfalls where additional corrective actions are needed to help achieve compliance limits.

Sampling activities were divided into four categories: (1) monthly grab sampling of selected outfalls and instream locations, (2) quarterly 5-day composite sampling, (3) storm sampling, and (4) longitudinal sampling of EFPC. Table 3.1 summarizes sampling information for all the key monitoring locations for mercury, including sites being monitored under the auspices of other programs [i.e., NPDES and best management practices (BMP)]. FY96 results from these surveys are presented and discussed below. In addition, data are presented from Tank $2100 \mathrm{U}$ overflow sampling and from a special $\mathrm{Hg}$ source characterization effort of selected catch basins upstream of Outfalls 163 and 169. Lastly, sediment in the UEFPC channel was characterized with respect to particle size distribution and mercury concentration as part of an ongoing effort to model stormflow transport of mercury (see Sect. 3.3).

\subsection{BASEMENT SUMPS}

Earlier results from comprehensive surveys of mercury in the 16 basement sumps in Bldgs. 9201-4 and 9201-5 suggested that these sumps, which discharged water directly into UEFPC primarily through Outfall 163 , contributed a significant $\mathrm{Hg}$ loading to the creek with estimates ranging from 5 to $10 \mathrm{~g} /$ day. The results of the sump survey were presented in last year's compliance report (Y/ER-251, Table 3.1). Flow from all but one of these sumps (Sump B of 9201-5) was diverted in late October 1995 into Tank $2100 \mathrm{U}$ (see Sect. 3.2 .10 below) for future treatment at the CMTS scheduled for completion in November 1996. Hg-contaminated water from the elevator sump in Bldg. 9204-4 will also be collected and transported to the CMTS in late 1996. Currently, the overflow from this tank discharges to the creek through Outfall 160 . New flow data for the sumps obtained in early 1996 (January 1-April 15) suggested that sump flows have decreased significantly compared with the 1994-1995 sump data presented in last year's report. 
'sə!!!!

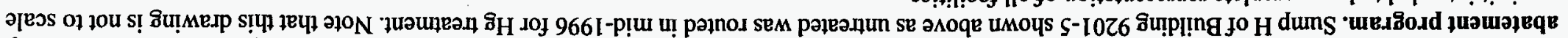

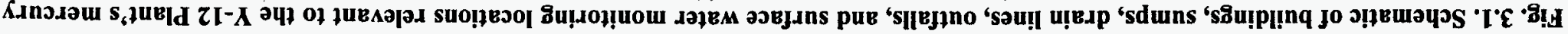

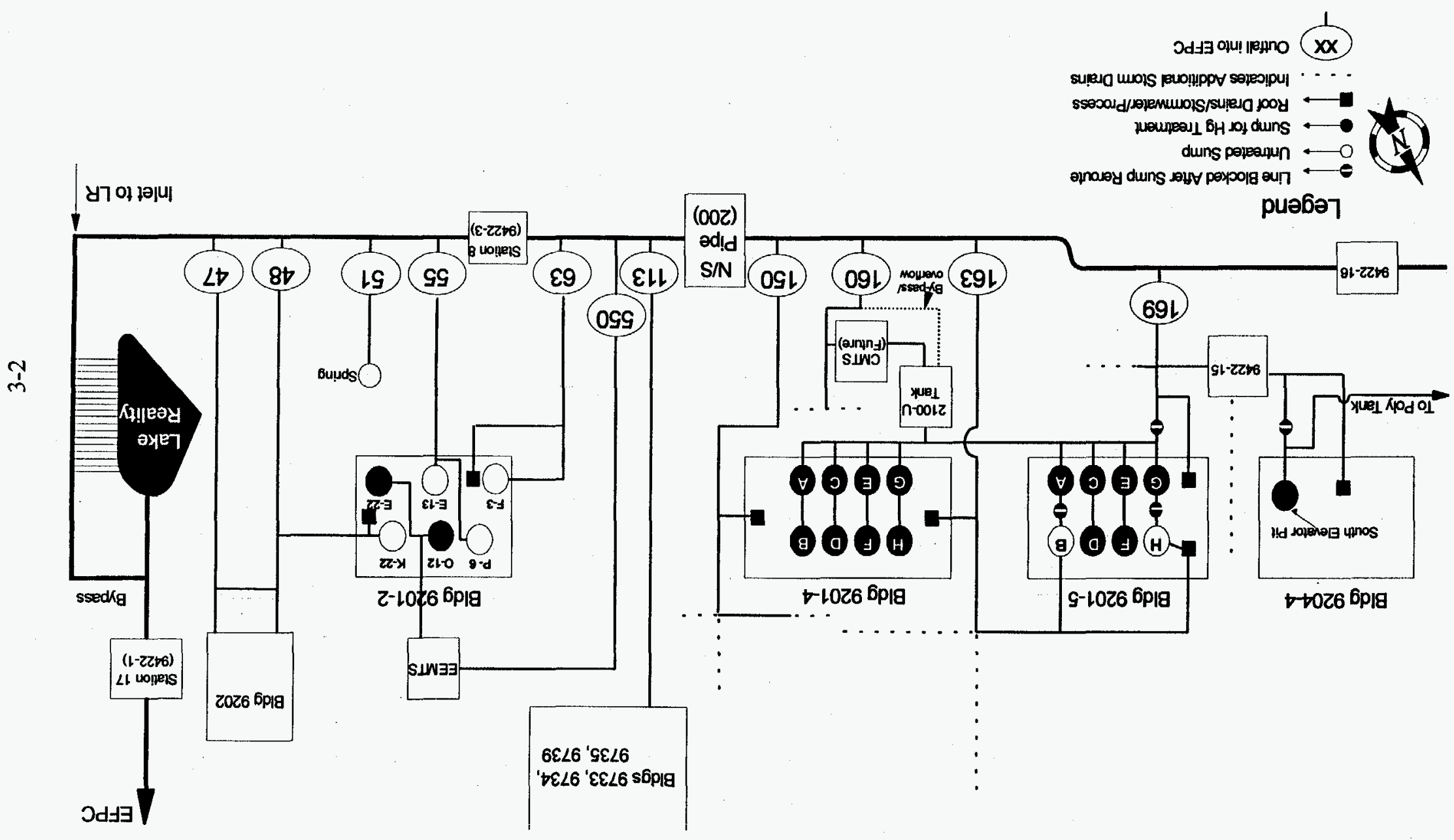


Table 3.1 Key Y-12 Plant mercury monitoring locations for FY 1996 and beyond.

(Flows given are from 1996 monthly averages and "best estimates" from available data)

\begin{tabular}{|c|c|c|c|c|c|c|c|c|}
\hline Location & Flow frequency & Flow device & Flow quality & $\begin{array}{l}\text { Dry weather } \\
\text { flow gpm) }\end{array}$ & $\begin{array}{c}\text { Hg sample } \\
\text { type }\end{array}$ & $\begin{array}{l}\text { Hg sample } \\
\text { frequency }\end{array}$ & Program & Comments \\
\hline $\begin{array}{l}\text { Station } 17 \\
(9422-1)\end{array}$ & Continuous & $\begin{array}{c}\text { T-flume, USGS } \\
\text { rated }\end{array}$ & Excellent & $2100^{\prime}(5000)$ & $\begin{array}{l}\text { Grab, } \\
\text { daily comp }\end{array}$ & Daily & NPDES & $\begin{array}{l}\text { Prelim. evaluation of } \\
\text { composite data }\end{array}$ \\
\hline $\begin{array}{l}\text { Outfall } \\
47 / 48\end{array}$ & Intermittent & $\mathrm{L} 60^{\circ} \mathrm{T}$-flume & Good & 24 & $\begin{array}{l}\text { Grab, } \\
\text { qtr comp }\end{array}$ & Monthly & RMPE & $\begin{array}{l}\text { Installed old flume from } \\
\text { Outfall } 160 \text { (Feb. 96) }\end{array}$ \\
\hline Outfall 51 & Continuous & Manning eq & Poor & $100-150$ & Grab & Weekly & NPDES & \\
\hline $\begin{array}{l}\text { Station } 8 \\
(9422-3)\end{array}$ & Continuous & $\begin{array}{l}\text { T-flume, USGS } \\
\text { rated }\end{array}$ & Excellent & $1600^{1}(4750)$ & Grab & Daily & BMP & \\
\hline Outfall 113 & Intermittent & Bucket gaged & Excellent & 1.2 & Grab & Monthly & RMPE & \\
\hline $\begin{array}{l}\text { N/S Pipe } \\
(200 / 201)\end{array}$ & Continuous & $\begin{array}{l}\text { Flume, } \\
\text { manning eq }\end{array}$ & Poor to? & -1200 & Grab & Monthly & RMPE & $\begin{array}{c}\text { Installed new band } \\
\text { upstream of outlet (Sept. } \\
96 \text { ) }\end{array}$ \\
\hline Outfall 163 & Continuous & $\mathrm{XL} 60^{\circ} \mathrm{T}$-flume & Good & 266 & $\begin{array}{l}\text { Grab, } \\
\text { qtr comp }\end{array}$ & Monthly & RMPE & \\
\hline Outfall 169 & Continuous & $2 " 45^{\circ} \mathrm{T}$-flume & Good & 168 & $\begin{array}{l}\text { Grab, } \\
\text { qtr comp }\end{array}$ & Monthly & RMPE & $\begin{array}{l}\text { Installed new 2" } 45^{\circ} \\
\text { T-flume (Jan. 96) }\end{array}$ \\
\hline $\begin{array}{l}\text { Tank } \\
2100 U\end{array}$ & Continuous & $\begin{array}{l}\text { Triple V-notch } \\
\text { weir }\end{array}$ & Good & 8 to 9 & $\begin{array}{l}\text { Grab, qtr } \\
\text { comp }\end{array}$ & Monthly & RMPE & \\
\hline $9422-15^{3}$ & Continuous & Manning eq & Fair & 114 & $\begin{array}{l}\text { Grab, } \\
\text { qtr comp }\end{array}$ & Monthly. & RMPE & $\begin{array}{l}\text { Install } 2^{\prime \prime} 45^{\circ} \\
\text { T-flume }\end{array}$ \\
\hline $9422-16$ & Continious & Manning eq & Fair & 56 & Grab & Monthly & RMPE & \\
\hline
\end{tabular}

\footnotetext{
${ }^{1}$ Flow augmentation begun in late July has greatly increased instream flows. Estimated flow after augmentation given in parentheses.
} 
The new data, shown in Table 3.2 for comparison with 1994-1995 data, represent sump flows measured after process water and steam condensate overflow were removed from the basement sumps. As a result of the reroutes, sump flows decreased by more than $50 \%$ translating into an $\sim 50 \%$ reduction in $\mathrm{Hg}$ loading (see Table 3.2). This $\mathrm{Hg}$ loading calculation assumes that average $\mathrm{Hg}$ concentrations have remained the same since the last period of sump sampling conducted in 1994 and 1995. This assumption, however, has not been tested by resampling the sumps in 1996.

Table 3.2 Results of sump water sampling in Bldgs. 9201-4, 9201-5 and 9204-4 and estimates of loading based on flow before and after pipe reroutes. (Average total $\mathrm{Hg}$ concentrations for 1994 and 1995 were used for calculating $\mathrm{Hg}$ loadings)

\begin{tabular}{|c|c|c|c|c|c|c|}
\hline Building & Sump & $\begin{array}{l}\text { Average total } \\
\mathrm{Hg} \mathrm{94-95} \\
(\mu \mathrm{g} / \mathrm{L})\end{array}$ & $\begin{array}{l}\text { Pre reroute } \\
\text { flow }(\mathrm{gpm})\end{array}$ & $\begin{array}{c}\text { Pre reroute } \mathrm{Hg} \\
\text { load (g/day) }\end{array}$ & $\begin{array}{l}\text { Post reroute } \\
\text { flow }(\mathrm{gpm})\end{array}$ & $\begin{array}{c}\text { Post reroute } \mathrm{Hg} \\
\text { load (g/day) }\end{array}$ \\
\hline $9201-4$ & A & 1.2 & 1.68 & 0.011 & 0.03 & $<0.001$ \\
\hline $9201-4$ & B & 243 & 0.04 & 0.053 & 0.04 & 0.053 \\
\hline $9201-4$ & C & 23 & 0.34 & 0.043 & 0.00 & 0.000 \\
\hline $9201-4$ & D & 39 & 0.49 & 0.103 & 0.27 & 0.057 \\
\hline $9201-4$ & E & 200 & 0.47 & 0.512 & 0.58 & 0.632 \\
\hline $9201-4$ & $F$ & 218 & 0.66 & 0.783 & 0.60 & 0.712 \\
\hline $9201-4$ & G & 9.8 & 3.39 & 0.182 & 2.56 & 0.137 \\
\hline $9201-4$ & $\mathbf{H}$ & 21 & 0.1 & 0.011 & 0.23 & 0.025 \\
\hline $9201-5$ & A & 4.7 & 2.85 & 0.073 & 0.74 & 0.019 \\
\hline $9201-5$ & B & 0.25 & 0.05 & 0.000 & 0.05 & 0.000 \\
\hline $9201-5$ & $\mathrm{C}$ & 109 & 2.18 & 1.289 & 0.27 & 0.160 \\
\hline $9201-5$ & D & 24 & 3.6 & 0.476 & 0.74 & 0.098 \\
\hline $9201-5$ & $E$ & 76 & 1.3 & 0.540 & $1.3^{2}$ & $0.540^{\mathrm{b}}$ \\
\hline $9201-5$ & $\mathbf{F}$ & 398 & 0.33 & 0.715 & 0.00 & 0.000 \\
\hline $9201-5$ & G & 21 & 1 & 0.113 & 1.27 & 0.144 \\
\hline $9201-5$ & $\mathrm{H}$ & 1.6 & 6.48 & 0.055 & $3^{a}$ & $0.025^{b}$ \\
\hline \multirow[t]{2}{*}{$9204-4$} & Elevator & 36 & 0.04 & 0.008 & 0.04 & 0.008 \\
\hline & Sum & & 25 & 4.968 & 11.72 & 2.610 \\
\hline
\end{tabular}

${ }^{2}$ Estimated flows. ${ }^{b}$ Calculated from estimated flows. 


\subsection{OUTFALLS AND OTHER SURFACE WATER MONITORING SITES}

Results from a 1993 comprehensive sampling and analysis of all outfalls that were flowing during dry weather and from the FY95 sampling results were used to prepare a list of outfalls to be sampled monthly and/or quarterly for further evaluation as mercury sources to the creek. The final list included $47 / 48,113,150,160,163,169$ and 200 (also known as the North/South Pipe or N/S Pipe). Outfalls 49 and 55, once major contributors of mercury to the creek, were dropped from the list of sites to monitor because of the elimination (Outfall 49) or reroute of flow through the IHgTU in late 1994 and subsequently EEMTS in May 1996. Outfall 55, however, is being monitored as part of the Y-12 NPDES permit agreement, and a discussion of the results of this monitoring, as well as for Outfall 51 , is given below. To appear on the list, an outfall generally must have exceeded $2.0 \mu \mathrm{g} / \mathrm{L}$ in mercury concentration or $1.0 \mathrm{~g} /$ day in loading at least once during the 1993 survey or must be a major contributor of flow to UEFPC (e.g., Outfall 150 ) and, thus, potentially a major contributor to $\mathrm{Hg}$ loading.

In addition to outfalls, other key surface water monitoring sites have been selected for continuing evaluation. These include Station 17 (9422-1), Station 8 (9422-3), 9422-15, and 9422-16. The overflow from Tank $2100 \mathrm{U}$ was also added in December 1995 to the list of monitored sites. The relative locations of these outfalls and other monitoring sites are shown in Fig. 3.1. Summary tables of the monthly and quarterly RMPE sampling results are presented in Appendixes A and B. In addition to the monthly and quarterly sampling conducted at these sites, an effort was made to improve the accuracy and reliability of flow monitoring data at selected sites through the installation of new flumes, either where no flume previously existed or to replace flumes undersized for the site. In addition, flow monitoring equipment was recalibrated at all existing flow monitoring sites in early February 1996.

\subsubsection{Outfall $47 / 48$}

These outfalls, which are interconnected (Fig. 3.1), receive dry weather flow from the Y-12 Development Division complex (e.g., Bldg. 9202) and wet weather flow from the northeastern corner of 9201-2. Historical mercury spills were recorded within this subbasin both at 9202 and 9201-2 (see Union Carbide report Y/EX-24 "Mercury at the Y-12 Plant"). As indicated in Fig. 3.2, these outfalls approached or exceeded the concentration $(2 \mu \mathrm{g} / \mathrm{L})$ or loading ( $1 \mathrm{~g} /$ day) criteria during the 1993 survey. However, mercury concentrations declined over the summer of 1995 apparently in response to pipe reroutes, and perhaps to the addition of tablet dechlorinators on several flows at 9202 (see Y/ER-251).

Monthly grab sample $\mathrm{Hg}$ concentrations at Outfall 47 (Outfall 48 was dry) over the period beginning June 20, 1995 and ending October 10, 1995 averaged $0.68 \mu \mathrm{g} / \mathrm{L}(\mathrm{N}=5)$. Monthly (grab) and quarterly (5-day, 24-h composite) monitoring of these outfalls was continued through FY96 to ensure that the observed decline in $\mathrm{Hg}$ loading during 1995 was permanent. Some adjustments in the final destination (storm or sanitary sewer) of discharges from 9202 were still in progress and potentially could have altered the mercury loading at these outfalls. A sandbag was placed in the common catch basin for these two outfalls to divert dry-weather flow from Outfall 48 through Outfall 47 before sampling began. In addition the large $60^{\circ} \mathrm{V}$-trapezoidal flume removed from Outfall 160 was installed in February 1996 to improve flow data at this site. 


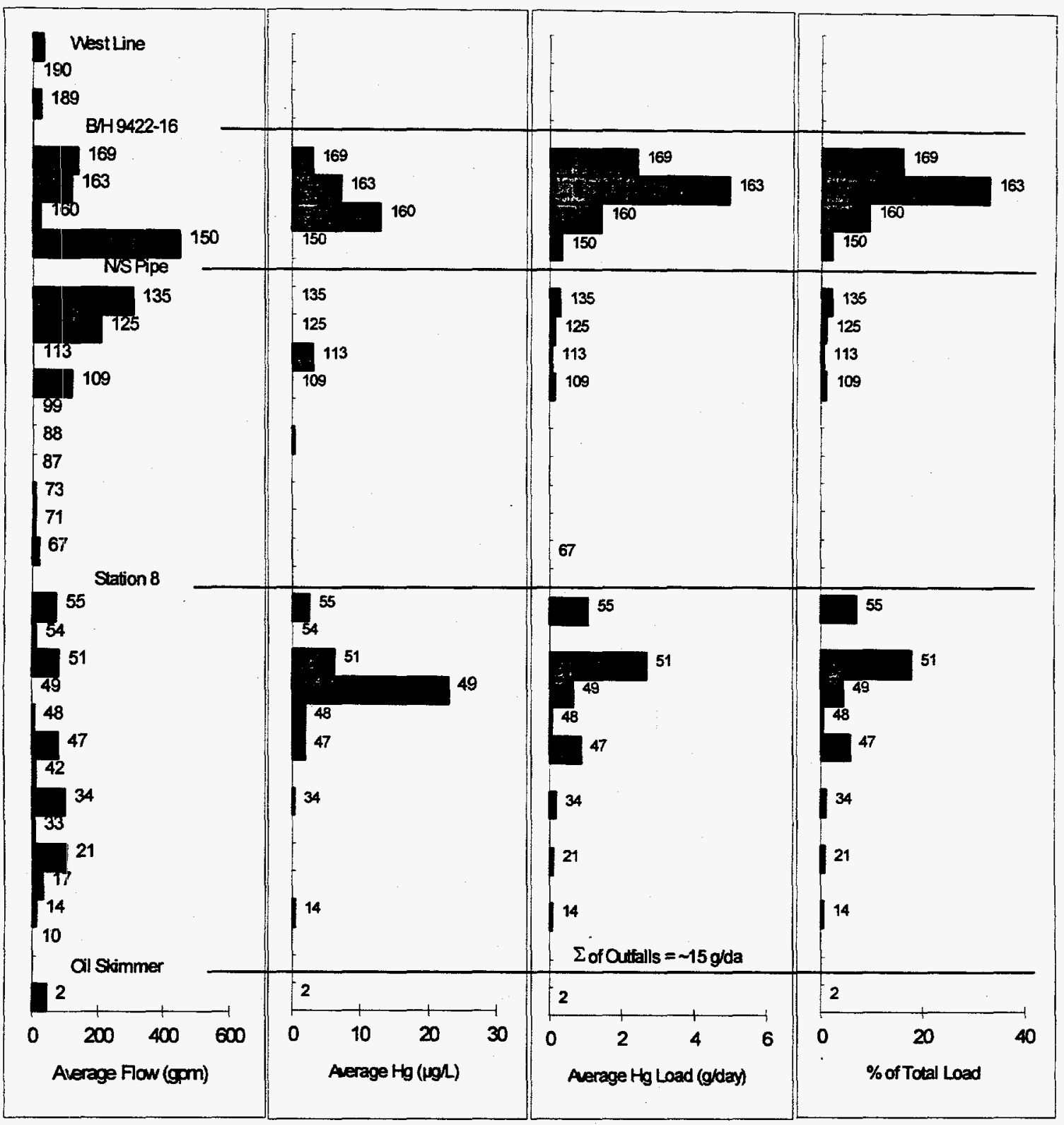

Fig. 3.2. Average dry weather flow, mercury concentration, mercury loading, and percent of total mercury loading for outfalls sampled four or more times between July and December 1993. Estimated total dry weather loading for all outfalls is approximately $15 \mathrm{~g} /$ day.

During FY96, the mercury concentration of monthly grab samples at this site continued its decline, averaging less than $0.24 \mu \mathrm{g} / \mathrm{L}$, with mercury concentrations in 7 of the 11 grab samples being less than the lower reporting limit (LRL) of $0.2 \mu \mathrm{g} / \mathrm{L}$. Fig. 3.3 shows an update, based on FY96 monitoring results, of the loading from Outfall $47 / 48$ in relationship to other Y-12 outfalls. Average dry weather loading from these two outfalls now appears to be less than $0.03 \mathrm{~g} /$ day (see Appendix A). Results from the first and second quarter 24-h composite sampling support this in that 9 of the 11 samples analyzed had $\mathrm{Hg}$ concentrations lower than the LRL and maximum loadings less than 
$0.1 \mathrm{~g} /$ day (see Appendix B). The highest $\mathrm{Hg}$ concentration reported for a 24-h composite sample was only $0.3 \mu \mathrm{g} / \mathrm{L}$.

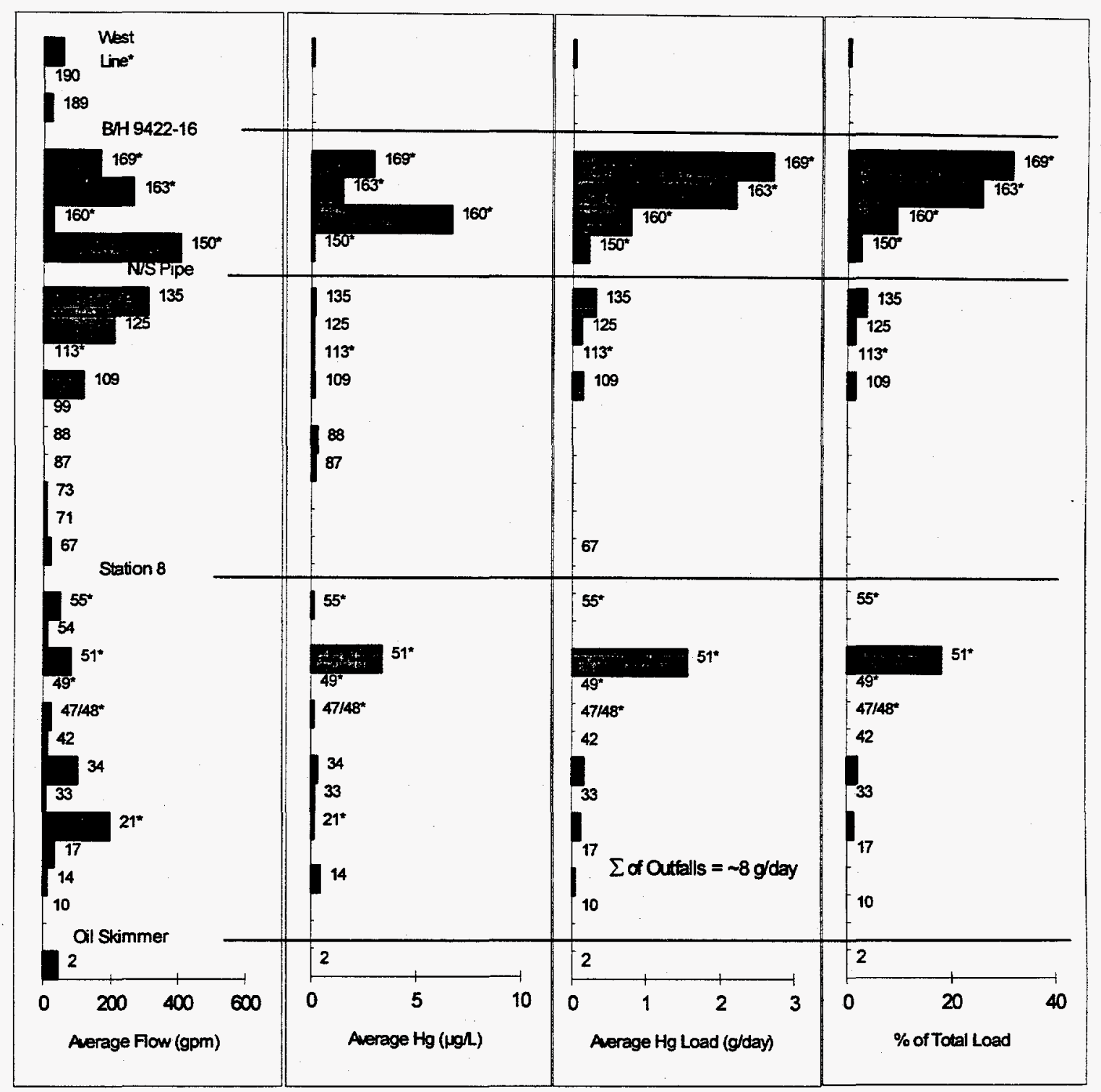

Fig. 3.3. Average dry weather flow, mercury concentration, mercury loading, and percent of total mercury loading for Y-12 outfalls during FY 1996. Data for outfalls flagged with an asterisk are average values from monthly dry weather sampling conducted during FY 1996. 1993-1994 data are used for remaining outfalls. Estimated total dry weather loading for all outfalls is approximately $8 \mathrm{~g} /$ day.

$\mathrm{Hg}$ values for two of the composite samples, collected during a 24-h period during which there was significant rainfall, were $\leq 0.2 \mu \mathrm{g} / \mathrm{L}$. Because of the absence of significant $\mathrm{Hg}$ loading at Outfall 47/48, a decision was made before the third quarterly composite sampling to relocate the ISCO sampler from Outfall $47 / 48$ to a new location, a drain pipe emptying into catch basin E3250. Results of catch basin sampling are presented in Sect. 3.2.16. In early September 1996, the 24-in. V-trapezoidal flume was removed from Outfall $47 / 48$ and installed at the catch basin. 


\subsubsection{Outfall 49}

This outfall, which was eliminated in July 1994, received process and sump water from the eastern section of Bldg. 9201-2. In the 1980s and early 1990 s water flow from this outfall ranged from 30 to $40 \mathrm{gpm}$, mercury concentrations ranged from 13 to $41 \mu \mathrm{g} / \mathrm{L}$, and the site represented the largest source of $\mathrm{Hg}$ in the eastern end of the Y-12 Plant (see Fig. 3.2). After the outfall was eliminated (as discussed briefly above and in more detail in Y/ER-251), all flow to the outfall was diverted through clean pipes to Outfall 55 or to the EEMTS.

\subsubsection{Outfall 51}

This outfall drains a large spring located just south of Bldg. 9201-2. Estimated mercury loading from this outfall appears to vary between approximately 2 and $4 \mathrm{~g} /$ day. A precise value is problematic due to the difficulty of obtaining accurate flow data when flows are high in the creek. The outfall becomes embayed (i.e., partially submerged) under high-flow conditions, which translates into overestimates of flow by the meter installed at the site. Recently, this problem has been aggravated by the initiation of raw water flow augmentation in the creek. FY96 mercury concentrations at this outfall (samples are taken weekly through the NPDES program) have ranged from 1.7 to $6.8 \mu \mathrm{g} / \mathrm{L}$, averaging $3.4 \mu \mathrm{g} / \mathrm{L}$ since October $1995(\mathrm{~N}=55)$. $\mathrm{Hg}$ results are presented in Fig. 3.4 and in Appendix C. Flow data, though available, are not presented due to the problem of obtaining good flow measurements as discussed above. Because of the unique form of mercury $(>20 \%$ is in the elemental form and up to $80 \%$ is easily reducible to the elemental form) at this outfall, this site has been the subject of research and development efforts directed at identifying cost-effective treatments through the air-stripping of volatile mercury. Sect. 2.4 discussed results of these efforts.

\subsubsection{Outfall 55}

This outfall receives process and sump water from Bldg. 9201-2 and is sampled twice a week as part of the NPDES program. Before strategic pipe replacement (source elimination) and sump water treatment (EEMTS), mercury concentrations at this outfall averaged about $2 \mu \mathrm{g} / \mathrm{L}$ while $\mathrm{Hg}$ loading ranged up to slightly over $1 \mathrm{~g} /$ day (see Fig. 3.5). Since April 1995, mercury concentrations have consistently been less than the LRL of $0.2 \mu \mathrm{g} / \mathrm{L}$. Of the 99 samples from Outfall 55 collected and analyzed during FY96 as part of the NPDES monitoring, Hg concentration in 98 of the samples was below the LRL. The one reportable concentration was equivalent to the LRL, i.e., $0.2 \mu \mathrm{g} / \mathrm{L}$. Daily flow rates over this same time period ranged from 14,300 to $136,500 \mathrm{gal} /$ day, averaging $69,300 \mathrm{gal} / \mathrm{day}$ $(\mathrm{N}=381)$. Complete sampling results are presented in Appendix D.

\subsubsection{Outfall 113}

This outfall receives process and cooling water from several buildings, including Bldgs. 9731, 9735,9736 , and 9737 , which house, or have housed, research and development laboratories. Dry weather flow from this outfall has been low $(<5 \mathrm{gpm})$ since 1993 and has averaged approximately $1 \mathrm{gpm}$ during the FY96 monthly sampling effort. Previously, mercury concentrations have most often been close to or less than the reporting limit of $0.2 \mu \mathrm{g} / \mathrm{L}$, but twice in 1993 the mercury concentration was high $(7.3$ and $2.3 \mu \mathrm{g} / \mathrm{L})$. Because of this, the outfall was added to the list of sites to be monitored monthly through FY96. Hg results for the monthly grab samples (see Appendix A) taken at this site were all less than the minimum reportable limit $(<0.2 \mu \mathrm{g} / \mathrm{L}, \mathrm{N}=11)$. It is recommended that this site be dropped from future dry-weather monitoring efforts since neither its flow nor its $\mathrm{Hg}$ concentration warrant cause for concern under dry weather conditions. 


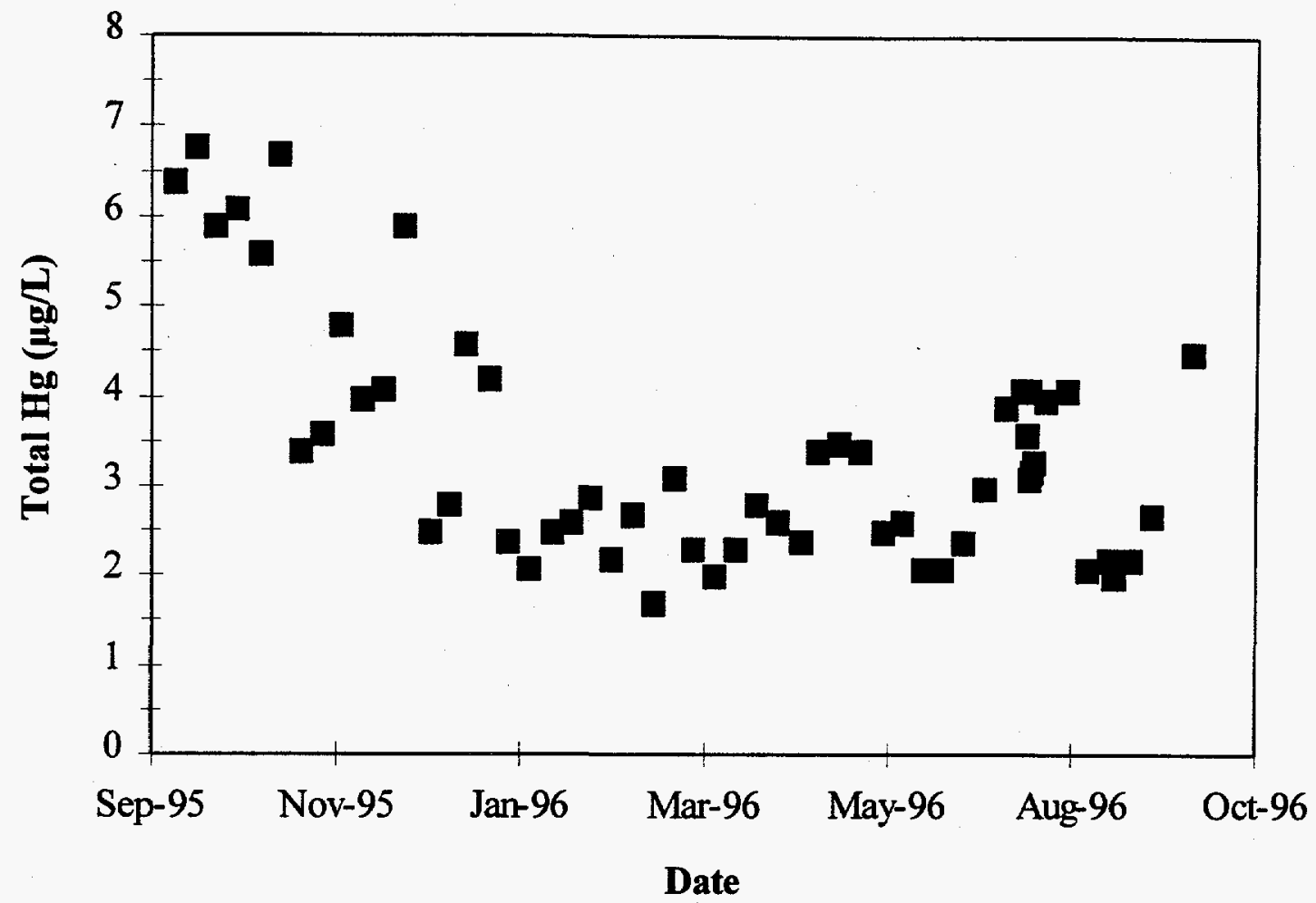

Fig. 3.4. Mercury results for Outfall 51 during FY 1996. Complete data, including the date of collection for each sample, are given in Appendix C.

\subsubsection{Outfall 150}

Historically (1982-83), this outfall, which drains the area just east of 9201-4 (Fig. 3.1), contributed 10 to $20 \mathrm{~g}$ /day of mercury to the creek with flows as high as $900 \mathrm{gpm}$. Water flow from this outfall is among the highest of any at $\mathrm{Y}-12$ and thus even low mercury concentrations can mean significant mercury loadings. However, recent sampling of this outfall conducted in the 1990s has revealed $\mathrm{Hg}$ concentrations below the LRL. During the comprehensive survey conducted in 1993 mercury concentrations were all below the LRL of $0.2 \mu \mathrm{g} / \mathrm{L}$ except for the last comprehensive sampling event on December 16,1993, when the concentration was $0.25 \mu \mathrm{g} / \mathrm{L}$. All results from subsequent sampling through December 1995 have been less than the reporting limit (Appendix A) with flow averaging approximately $400 \mathrm{gpm}$. Possible explanations for the large decrease in $\mathrm{Hg}$ loading may include the extensive storm drain cleaning and relining completed in 1986 as well as the rerouting of some sump discharges to other outfalls. After December 1995, this sampling site was dropped from the list of sites for monthly dry weather grab samples in favor of initiating sampling of Tank $2100 \mathrm{U}$.

\subsubsection{Outfall 160}

This outfall drains the area immediately south of $9201-4$, which includes the $2100 \mathrm{U}$ tank, the Central Pollution Control Facility, and several cooling towers (Fig. 3.1). Flows have generally ranged during dry weather conditions from approximately 5 to $50 \mathrm{gpm}$ (see Appendix A). To obtain better flow data during high flows, the flume at this outfall was replaced on January 27,1996 , with a larger 
flume (XI $60^{\circ} \mathrm{V}$-trapezoidal flume) capable of handling higher flows. The flume was calibrated using a standard 0 - to $1-\mathrm{ft}$ discharge table extended for heads up to $2.5 \mathrm{ft}$.

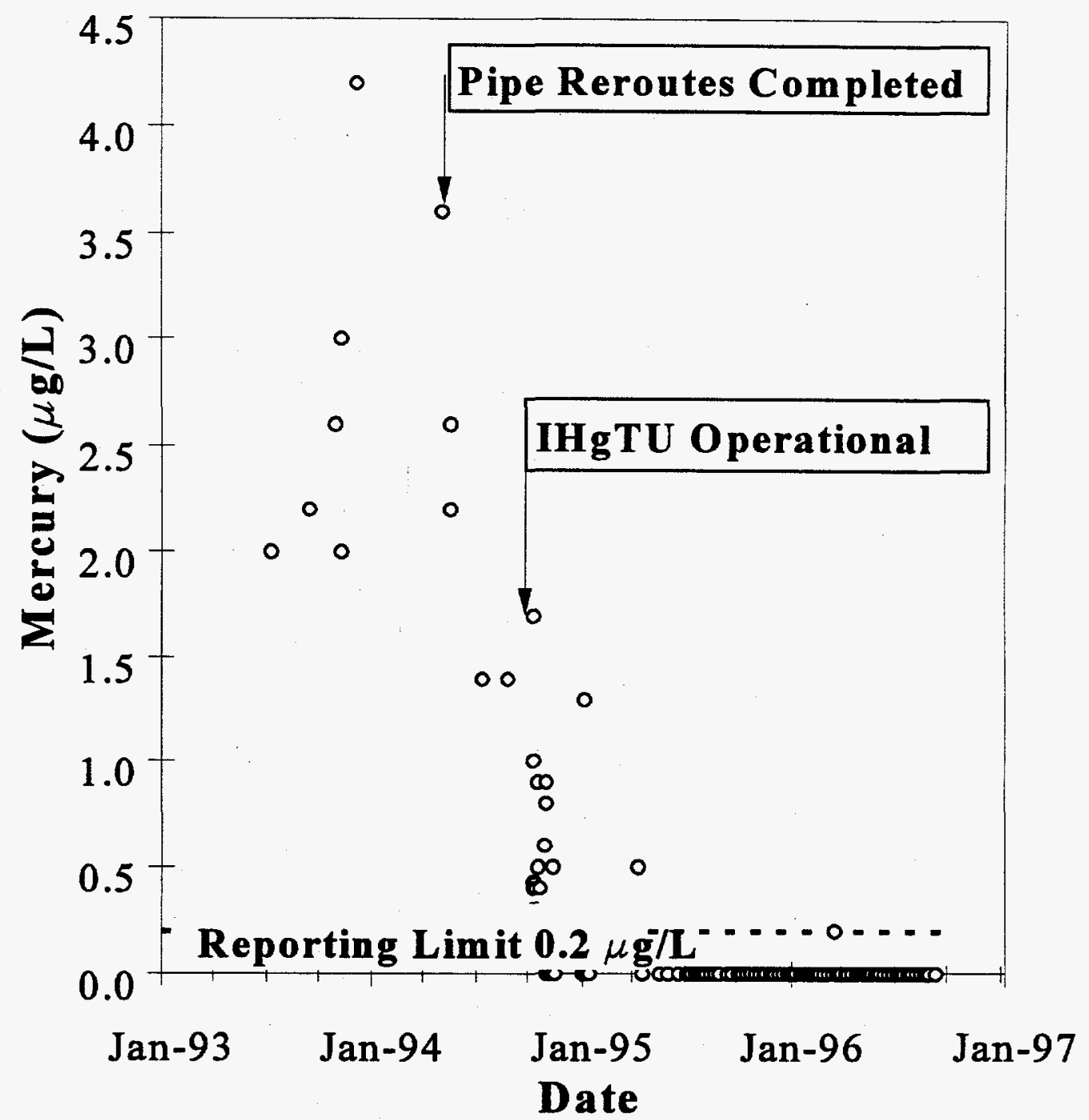

Fig. 3.5. Temporal trend in mercury concentrations measured in Outfall 55 through September 9, 1996.

Historically (1982-1983), mercury concentrations and loadings at this outfall have ranged up to $60 \mu \mathrm{g} / \mathrm{L}$ and $20 \mathrm{~g} /$ day, respectively. During the 1993 comprehensive survey, mercury concentrations and loadings varied from 9 to $18 \mu \mathrm{g} / \mathrm{L}$ and 0.6 to $2 \mathrm{~g} /$ day, respectively. Following upgrades to the Tank 2100U, all sump discharges from Bldgs. 9201-4 and 9201-5 ultimately destined for treatment in the CMTS were valved (late October 1995) through the tank and thus to Outfall 160. However, measurements of flow, $\mathrm{Hg}$ concentration, and $\mathrm{Hg}$ loading during FY96 at Outfall 160 do not seem to reflect the addition of sump water. 
1996 values for $\mathrm{Hg}$ concentrations and loadings during dry weather conditions (see Appendix A and Appendix B) are comparable to those reported for the 1993 comprehensive survey (i.e., FY96 flows ranged from 6 to $51 \mathrm{gpm}, \mathrm{Hg}$ from 1.8 to $15 \mu \mathrm{g} / \mathrm{L}$, and $\mathrm{Hg}$ loading from $<1$ to $1.5 \mathrm{~g} /$ day) before the sump water was rerouted. Although there are data indicating that sump flows (and, by calculation, $\mathrm{Hg}$ loading) have declined since pipe rerouting in late 1994 (see Sect. 3.1), and there is evidence suggesting loss of mercury between the Tank 2100 U weir and Outfall 160 , this cannot explain all the discrepancy. Possible reasons for the lower-than-expected $\mathrm{Hg}$ loading at the outfall are discussed in Sect. 3.2.10 below.

\subsubsection{Outfall 163}

This outfall serves the area immediately west of $9201-4$, immediately east of $9201-5$, and a large area north of both buildings (Fig. 3.1). Before late October 1995, Outfall 163 received most of the sump discharges from Bldgs. 9201-4 and 9201-5. Access for flow measurement and sampling at the point where the outfall joins the main trunkline (extension of N/S Pipe) was not established until early 1995 and flow measurements for the outfall before this date are largely under estimated. FY 96 dry weather flows averaged $266 \mathrm{gpm}$, similar to the average reported in Y/ER-251 for 1995 (250 gpm).

Results of the 1993 comprehensive survey for this outfall showed only limited variations in mercury concentrations (6.5 to $7.8 \mu \mathrm{g} / \mathrm{L}$ ), with loading averaging around $5 \mathrm{~g} /$ day (Fig. 3.2). Results from FY95 monitoring (see Y/ER-251) of this outfall reported mercury concentrations $(0.7$ to $1.3 \mu \mathrm{g} / \mathrm{L}$ ) and loadings ( 1 to $2 \mathrm{~g} /$ day) considerably lower than the $5 \mathrm{~g} /$ day measured during the 1993 comprehensive survey (see Figs. 3.2 and 3.3), possibly reflecting lower inputs of sump water to the outfall. In late October 1995, the sump water was diverted from Outfall 163 to Tank $2100 \mathrm{U}$ and Outfall 160.

Results of FY96 monthly and 24-h composite sampling (see Appendixes A and B) still indicate a significant source of $\mathrm{Hg}$ loading to the outfall even after sump water reroute (see Fig. 3.3). Results of the monthly dry weather sampling show average Hg concentration and loading for FY96 of $1.5 \mathrm{~g} /$ day and $2.2 \mathrm{~g} /$ day, respectively. The $24-\mathrm{h}$ composite data are similar, though somewhat lower, in both concentration and loading. Efforts to identify additional sources of $\mathrm{Hg}$ loading to the outfall were undertaken in 1996. Sect. 3.2.16 discusses those efforts.

\subsubsection{Outfall 169}

This outfall serves the south side of Bldg. 9201-5 and the area between and north of Bldgs. 9201-5 and 9204-4 (Fig. 3.1). Before the sump water was rerouted, Sumps G and H in Bldg. 9201-5 discharged to lines connected to this outfall. The elevator sump in Bldg. 9204-4 still discharges to the outfall, though it is scheduled for reroute in late 1996 to a polytank for transport to CMTS for treatment. In the early 1980 s, mercury loadings approaching 60 g/day were measured immediately upstream of this outfall and were traced largely to sources at 9204-4, which have been subsequently eliminated. A 2 -in., $45^{\circ}$ WSC V-trapezoidal flume was installed here on January 27 of this year to improve flow measurements.

Measured dry weather flows at this outfall in 1996 have usually been in the 130- to 200-gpm range, averaging approximately $170 \mathrm{gpm}$ (Appendix A). Mercury concentrations and loadings are similar to those reported for the 1993-1994 comprehensive survey (see Figs. 3.2 and 3.3) and during FY95, ranging from 2 to $5.7 \mu \mathrm{g} / \mathrm{L}$ (average $3 \mu \mathrm{g} / \mathrm{L}$ ) and 1.4 to $4.3 \mathrm{~g} /$ day (average $2.7 \mathrm{~g} /$ day), respectively. See Appendix A for complete monthly results. The most recent loadings (i.e., over the last 4 months) have averaged $<2$ g/day. 
As can be seen in Fig. 3.3, Outfall 169 presently appears to be the major contributor of $\mathrm{Hg}$ loading to UEFPC from the western end of the Y-12 Plant. Both the monthly grab and 24-h composite sampling suggest that $\mathrm{Hg}$ concentration at this outfall is greatly influenced by flow increases. During the first quarterly composite sampling event, approximately $0.5 \mathrm{in}$. of rain fell on the third day of sampling. The 24-h composite representing the initial flush from this storm had an $\mathrm{Hg}$ concentration of $40 \mu \mathrm{g} / \mathrm{L}$ with an estimated loading of $53 \mathrm{~g} /$ day (Appendix B) based on the flow during that 24-h period. The elevated $\mathrm{Hg}$ concentration and loading during the storm are also reflected in similar high values at Outfall 200 for the same 24 -h period. Also, the January grab sample taken during elevated flow had a mercury concentration double the average under normal flow conditions.

Since the sump water was removed from this outfall (except for the elevator sump, which contributes little in $\mathrm{Hg}$ loading - see Table 3.2), other sources of mercury have been sought to account for the loading at this location to achieve further reduction. Relatively low $\mathrm{Hg}$ loading for the two monitoring sites directly upstream of Outfall 169, i.e., 9422-15 and 9422-16 (see Sects. 3.2.11 and 3.2.12), implicates the area south of Bldg. 9201-5 as a potential source area. Sect. 3.2.16 discusses findings from additional source identification efforts undertaken in 1996.

\subsubsection{Tank 2100U}

Historically, Tank $2100 \mathrm{U}$ has been used as a settling tank for Hg-contaminated water and particulates pumped from the basement sumps of Bldg. 9201-4. In early 1993, approximately $19,000 \mathrm{~kg}$ of $\mathrm{Hg}$-contaminated sludge was removed from the tank as an interim action under the Comprehensive Environmental Response, Compensation, and Liability Act (CERCLA) as part of the Reduction of Mercury in Plant Effluents (RMPE) project. After being cleaned, the tank was returned to service; it currently receives all sump water from Bldgs. 9201-4 and 9201-5. Overflow from the tank is discharged to UEFPC through Outfall 160. Tank $2100 \mathrm{U}$ will be used as a surge tank for the CMTS upon its completion in FY97.

Monthly monitoring of the overflow from this tank began in December 1995. Samples are collected at a weir constructed downstream of the tank exit. Instantaneous flow from the tank ranges from 3 to $16 \mathrm{gpm}$ (average $8.3 \mathrm{gpm}$ ) based on flows recorded during monthly sampling (Appendix A). An instantaneous flow of $26 \mathrm{gpm}$ was recorded in January and is considered suspect because it was recorcled when the bubble flow meter installed at the tank weir was malfunctioning. Average daily flow was also calculated using the first and second quarter totalized flow (in gallons) recorded during the 24-h sampling periods of composite sampling (Appendix B). The calculated value of $9.2 \mathrm{gpm}$ agrees well with the average flow calculated from instantaneous flow. Monthly $\mathrm{Hg}$ values have varied from 24 to $47 \mu \mathrm{g} / \mathrm{L}$ (average $34 \mu \mathrm{g} / \mathrm{L}, \mathrm{N}=9$ ) and loadings from 0.6 to $3 \mathrm{~g} /$ day (average $1.5 \mathrm{~g} /$ day, $\mathrm{N}=8$ ). The Hg loading is less than expected even considering the recalculated contribution (based on lower flows) from the sumps (Table 3.2).

Several possible explanations come to mind for the less-than-expected $\mathrm{Hg}$ loading at this site. If the tank is indeed still acting as a settling tank for sump water and particulates, then the total $\mathrm{Hg}$ concentration at the exit of the tank would be expected to be lower than the $\mathrm{Hg}$ concentration entering the tank. Unfortunately, sampling of the inlet water is not done but perhaps should be in the future, if logistically possible. Another possible explanation is suggested by the results of the 24-h composite sampling (Appendix B). Hg concentrations for composite samples from Tank $2100 \mathrm{U}$ are $50 \%$ of the value recorded for total $\mathrm{Hg}$ in a grab sample (11 to $19 \mu \mathrm{g} / \mathrm{L}$ for a composite sample vs 24 to $47 \mu \mathrm{g} / \mathrm{L}$ for a grab sample) suggesting that $\mathrm{Hg}$ may be volatilizing out of the sample prior. 


\subsubsection{2-15}

This surface water monitoring site receives flow from the area between and north of Bldgs. 9201-5 and 9204-4. Flows ranged from 90 to $150 \mathrm{gpm}$ during the 1993 comprehensive outfall surveys and between 73 and 170 gpm during FY96 (see Appendixes A and B) averaging around $110 \mathrm{gpm}$. Average $\mathrm{Hg}$ concentrations for monthly grab samples is $0.68 \mu \mathrm{g} / \mathrm{L}$ and only about $0.3 \mu \mathrm{g} / \mathrm{L}$ for 24-h composite samples. Calculated $\mathrm{Hg}$ loadings in 1996 have averaged from $\sim 0.2$ to $\sim 0.4 \mathrm{~g} /$ day. This monitoring site contributes approximately two-thirds (110 gpm out of $170 \mathrm{gpm})$ of the water that passes Outfall 169 downstream; thus the higher Hg loading at Outfall 169 must have a source or sources (in the range of $2 \mathrm{~g} /$ day) in the area immediately south of Bldg. 9201-5. Limited upstream tracing in 1995 did not identify any significant sources. Additional effort was directed toward identifying sources directly south of Bldg. $9201-5$ in 1996; these results are presented in Sect. 3.2.16.

\subsubsection{2-16}

Although the monitoring site at $9422-16$ has not shown $\mathrm{Hg}$ concentrations or loadings indicative of important $\mathrm{Hg}$ sources upstream, the site is included among the key sites for mercury monitoring because it represents flow from a large portion of the western area of the Y-12 Plant west of Bldg. 9201-5, including areas suspected to be potential $\mathrm{Hg}$ sources. Some tributary lines originate from, or near, Bldg. 9204-4 and the area of former storage of empty mercury flasks. Dry weather flow at this site is strongly influenced by shallow groundwater infiltration from the eastern S-3 Pond plume, and by occasional treated wastewater discharges from the West End Treatment Facility and the Groundwater Treatment Facility. None of the latter sources of flow are significant sources of mercury. FY96 dry weather flows ranged from 34 to $80 \mathrm{gpm}$ (average $56 \mathrm{gpm}$ ) with mercury concentrations, both during the 1993 surveys and more recently, ranging narrowly between $<0.2$ to $0.6 \mu \mathrm{g} / \mathrm{L}$ (average $<0.3 \mu \mathrm{g} / \mathrm{L}$ ). This yields an average dry weather loading of less than $0.1 \mathrm{~g} /$ day (see Appendix A). This site will be dropped from routine dry weather monitoring since FY 96 results confirm past findings that this outfall is not an important source of $\mathrm{Hg}$, at least during dry weather flows.

\subsubsection{Outfall 200 (N/S Pipe)}

This surface water monitoring site (discharge of the N/S Pipe) represents the collected flow from several key mercury outfalls $(150,160,163,169)$ upstream, as well as all of the other drainage from the western area of the plant. Accurate flow monitoring has been difficult to obtain at this important site in the past without confined space entry for each measurement and continues to be so in 1996. Both have created conditions where water backs up at the mouth of the outfall potentially causing overestimates of flow. Flow measurements conducted here during the 1993 outfall survey using the area-velocity method indicated dry weather flows in the range 900 to $1200 \mathrm{gpm}$. Recent monitoring results for flow are in the 700 to $1600 \mathrm{gpm}$ range (Appendix A) and are considered no more than rough estimates because of the problems mentioned above.

In September 1996, staff from the Environmental Management Department (EMD) installed a sampling and flow monitoring site approximately $70 \mathrm{ft}$ upstream of the Outfall 200 discharge to avoid the influence of raw water flow on sampling and flow monitoring. One small pipe with approximately $6 \mathrm{gpm}$ of flow empties into the N/S Pipe between this new monitoring location and the location of the old Outfall 200. Flow from this small pipe will be sampled and analyzed to determine its contribution to $\mathrm{Hg}$ loading at Outfall 200. Mercury loadings determined at Outfall 200 during the 1993 survey ranged from 6 to $13 \mathrm{~g} /$ day while recent estimated loadings in 1995 and 1996 have been around $7 \mathrm{~g} /$ day during dry weather flow. Most of this loading (>80\%) in FY96 can be explained by inputs from Outfalls 160, 163 and 169 (see Fig. 3.3). 


\subsubsection{2-3 (Station 8)}

This surface water monitoring location is just upstream from the Hg-contaminated outfalls associated with Bldgs. 9201-2 and 9202. Since at least November 1992, the site has produced high quality stream flow data. Flow at the site is monitored by both the Y-12 Plant and the U.S. Geological Survey (USGS). The USGS publishes the data (USGS 03538231) annually in USGS Water Resources Data--Tennessee. Mercury loading at Station 8 plus the loading (about $3 \mathrm{~g} / \mathrm{day}$ ) from Outfall 51 currently represents our best estimate of total loading from the Y-12 Plant not confounded by deposition and resuspension of mercury in Lake Reality.

Daily or twice-daily grab samples for total mercury analysis have been collected at this site since 1989. The daily grab sampling at this location was discontinued at the end of August 1996. However, monthly dry weather samples will be taken as part of the FY 97 sampling and monitoring program. Dry weather mercury loadings at Station 8, determined during the 1993 comprehensive outfall surveys, were similar to those for the N/S Pipe and ranged from about 7 to $11 \mathrm{~g} /$ day. Combining the daily average flow data for this site with the daily $\mathrm{Hg}$ grab sample results allows calculation of daily mercury loadings. These daily loadings, shown below in Fig. 3.6 for the period January 1995 through Augusit 1996, include both dry and stormflow conditions and thus are more representative of total loading for the site and as a result are higher than the range given above. Annual average mercury loadings ( \pm standard error) calculated in this manner were $16 \pm 1.1,22 \pm 1.7,14 \pm 1.3$, and $13 \pm 1.3$ for 1993, 1994, 1995 and 1996 through August, respectively.

Annual variations in $\mathrm{Hg}$ loading for this site are strongly influenced by variations in annual rainfall. As pointed out in Y/ER-251, the higher average loading in 1994 is likely due to the very wet spring period in 1994. It is too soon to know the long-term effect of $\mathrm{Hg}$ loading at Station 8. If instream sources of $\mathrm{Hg}$ (i.e., sediment) are mobilized by the higher flows, then one might expect increases in $\mathrm{Hg}$ loading at Station 8, at least initially. Fig. 3.7 provides time plots through August 1996 of 3-month running average loadings for Station 8 for all average daily flows sampled and with daily flows greater than selected values (7, 10,12, and 15 million gal per day [MGD]) excluded.

\subsubsection{2-1 (Station 17)}

This site represents flow from essentially the entire Y-12 Plant site and is located on EFPC at the plant boundary (229 Line). The site also includes a small amount of direct surface runoff from non-DOE property to the east of Scarboro Road. Flow and constituent monitoring began here in November 1988 after the closure of New Hope Pond. Initial flow monitoring suffered problems related to the ultrasonic water level measuring system. Flow data are available prior to November 1992, but these are of unknown or variable quality and are not used here. The USGS began flow monitoring here (USGS 03538235) in November 1992 and publishes the daily average flow values annually in USGS Water Resources Data-Tennessee.

Mercury concentrations have been measured in daily, or twice-daily, grab samples from this site since it was established in 1988. Results of this monitoring through September 1996 are summarized in Fig. 3.8 as monthly averages. Sampling was twice-daily through January of 1992 and then daily beginning in February 1992. Short- (seasonal) and long-term temporal patterns are apparent in this graph. Regression of the mercury concentration data against time (Julian date) revealed a significant decline in concentration amounting to 10 to $15 \%$ per year since 1988 . A moving average reveals an annual cycle in mercury concentration superimposed on the longer term decline. The annual cycle was apparently missed in 1994, an exceptionally wet year, but returned in 1995 and is also present in 1996. The annual cycle is characterized by lower concentrations in the late winter through early summer, and 
higher concentrations in the summer through early winter months. This pattern is suggestive of the variable importance of groundwater inputs compared with Y-12 Plant effluents, i.e. the greater inputs of groundwater flow in mercury content during the wetter months tend to dilute mercury-contaminated effluents.

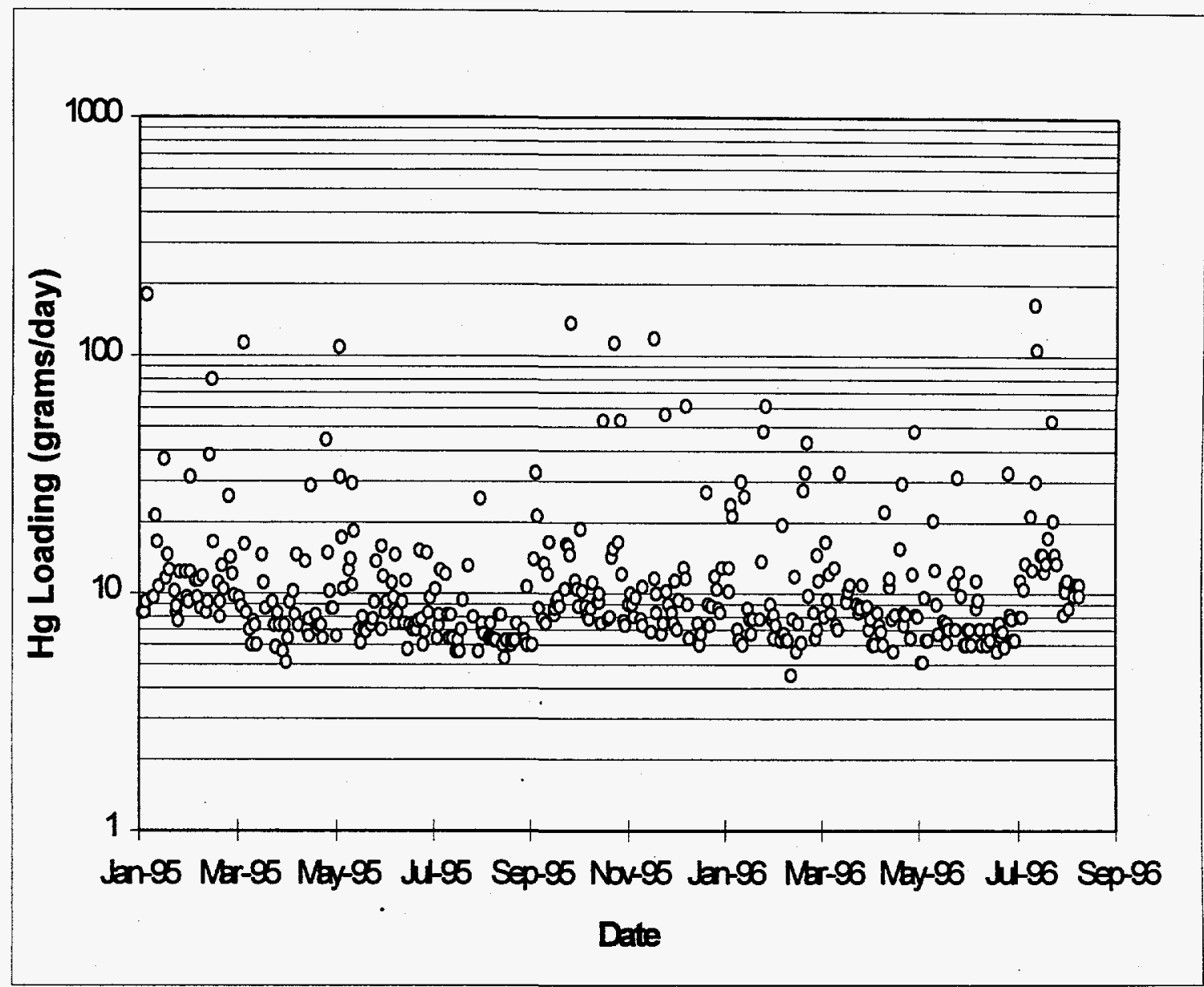

Fig. 3.6. Daily mercury loadings for Station 8 (9422-3) for 1995 and 1996 through August. Values are calculated as the product of mercury concentration of the daily grab sample and the average daily flow (USGS) on the day of sampling. Plot shows all loading values including storm values.

Mercury loading at Station 17 is tracked using various methods. For the purpose of compliance with the NPDES permit, a 3-month running average is used, with the exclusion of $\mathrm{Hg}$ values for days when average flow at Station 17 exceeds 15 MGD. Figure 3.9 plots running averages for all values and for days with average flows exceeding 7,10 and 12 MGD. The plot for flows less than 7 MGD is essentially equivalent to "dry weather" loading. The annual average daily loading ( \pm std. error) was $19 \pm 1.4,24 \pm 2.7,18 \pm 2.2$, and $26 \pm 6 \mathrm{~g} /$ day for $1993,1994,1995$, and for the first 9 months of 1996 , respectively, if no data are excluded from the averaging process. Exclusion of just two data points representing days when large back-to-back storms occurred on July 31 and August 1, 1996 has a profound effect on the mercury loading for 1996 , reducing the average to $18.8 \pm 1.4 \mathrm{~g} /$ day. The annual average daily loadings ( \pm std. error) were $18 \pm 1.0,17 \pm 0.7,14 \pm 1.2$ and $16 \pm 1.0 \mathrm{~g} /$ day for the same periods if flows greater than 15 MGD are excluded. Similarly, annual average dry weather loadings (flows >7 MGD excluded) were $14 \pm 0.3,15 \pm 0.4,11 \pm 0.4$ and $9.4 \pm 0.3 \mathrm{~g} /$ day. 


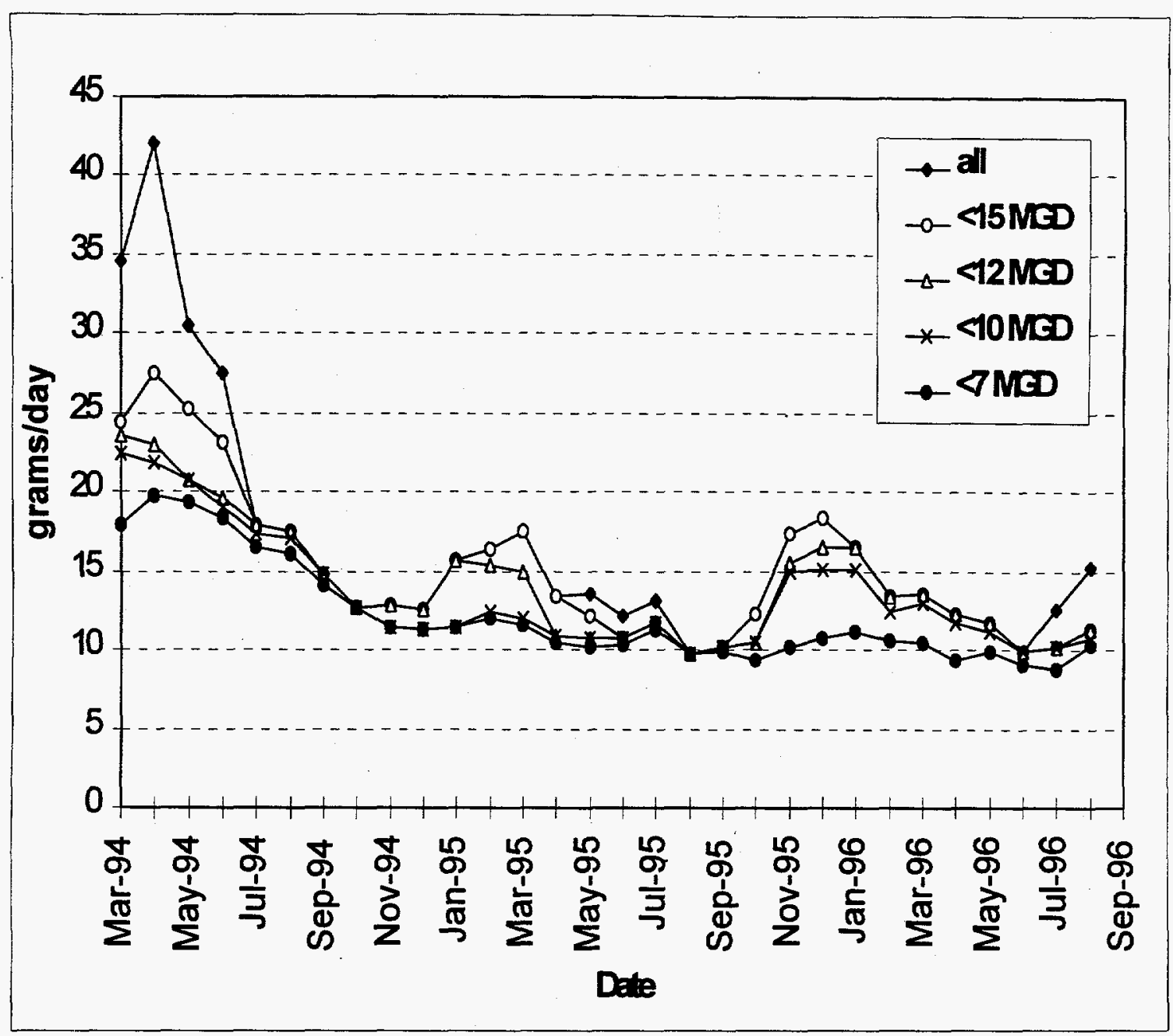

Fig. 3.7. Running 3-month average mercury loadings (grams/day) at Station 8 (9422-3) for all flows and for flows greater than 7, 10, 12, and 15 MGD excluded from the average. Results are for the period March 1994 through August 1996.

Due to raw water addition, which was initiated in late July, flows at Station 17 will be maintained at 27 MGD. Early monitoring data for Station 17 seem to indicate (Fig. 3.9) that with this increased dry weather flow, loadings have actually increased at Station 17 . One would expect $\mathrm{Hg}$ concentrations, and thus loadings, to have declined by $\sim 50 \%$ at Station 17 with the input of clean raw water, but a review of daily $\mathrm{Hg}$ values indicates no decrease in concentration suggesting that $\mathrm{Hg}$-contaminated sediments in the creek bed, or possibly Lake Reality, are being resuspended and transported downstream. Some temporary readjustment of the UEFPC channel sediments, including those in Lake Reality, was expected with the possibility of higher $\mathrm{Hg}$ loading at Station 17 for a brief period following initiation of flow management. Monitoring thus far has been insufficient to determine if any longer term effects will be observed.

Ironically, two of the largest peak storm flows of record occurred during two successive storms on July 31 and August 31, 1996, just a few days after raw water had achieved maximum anticipated flow. As discussed above, loading values for these two storm days profoundly affect all the running averages shown in Fig. 3.9 except that for flows less than 7 MGD and thus make seeing any effects 
of raw water addition difficult to separate from the effects of the unusually wet period, which was coincident with the addition of raw water.

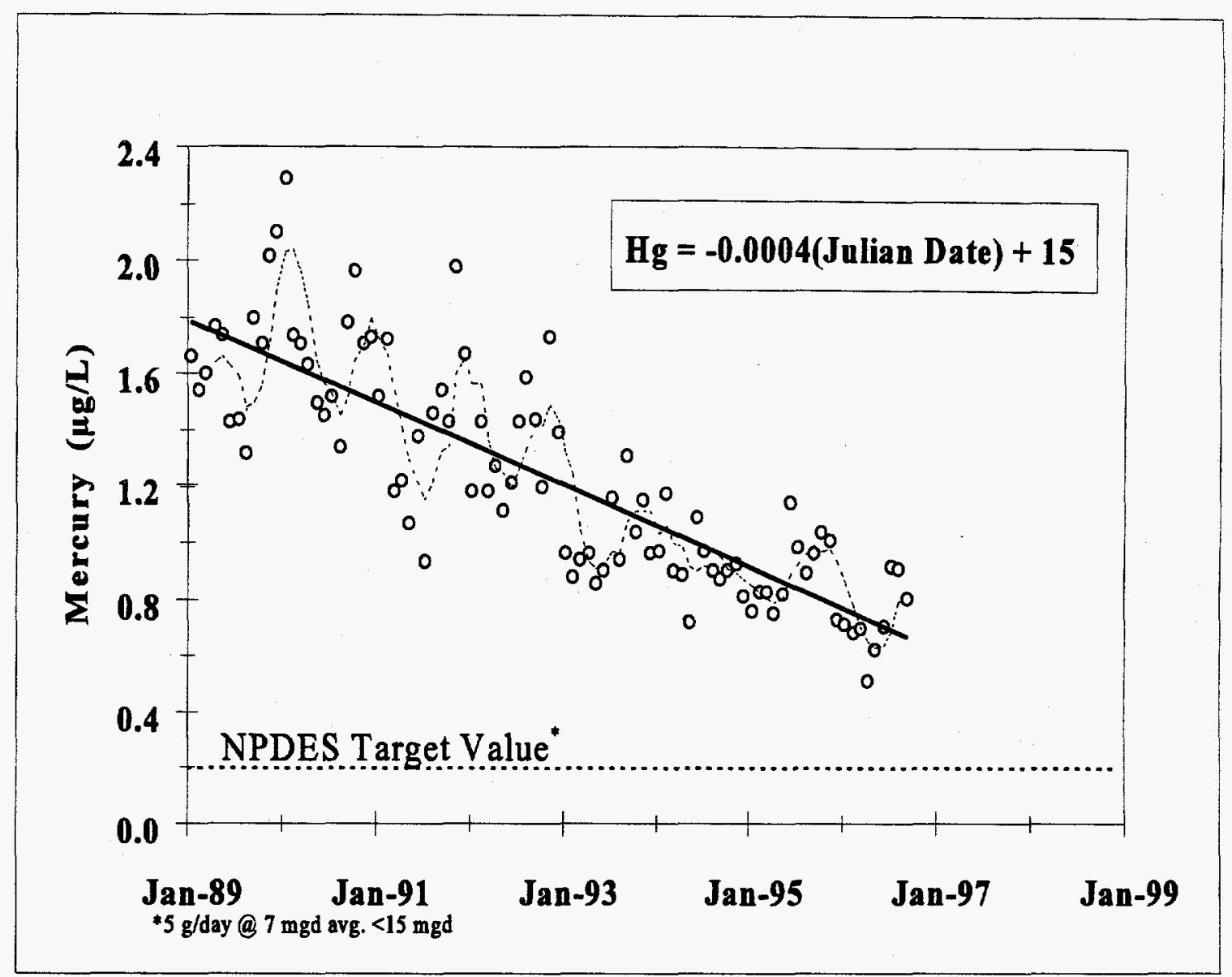

Fig. 3.8. Monthly average mercury concentration at Station 17 from January 1989 through September 1996. Solid line indicates regression line. The dashed line is a 4-month moving average and illustrates seasonal patterns in concentration.

A special study was conducted at Station 17 in January and February 1996 to investigate the importance of sampling intake location/position on $\mathrm{Hg}$ concentration in 24-h composite samples collected at the site. There was some concern prior to the study that the location of the intake of the BMP sampler collecting daily 24-h composites might not be optimal for collecting a sample representative of the water column but might be collecting samples biased with greater amounts of sediment than in the mid-stream water column. To allay this concern, a second ISCO sampler was installed at Station 17 to sample the same 24-h period as the BMP sampler.

Before sampling began, the BMP sampler was repositioned slightly to minimize proximity to the streambed. The second (ER) sampler was installed with the sample line suspended over the creek so that the sample intake was sampling the mid-stream water column. Both samplers were set up to run off of the same flowmeter, thus receiving signals simultaneously to take a sample. Nine 24-h composite samples, including a storm sample, were taken by both composite samplers and analyzed 


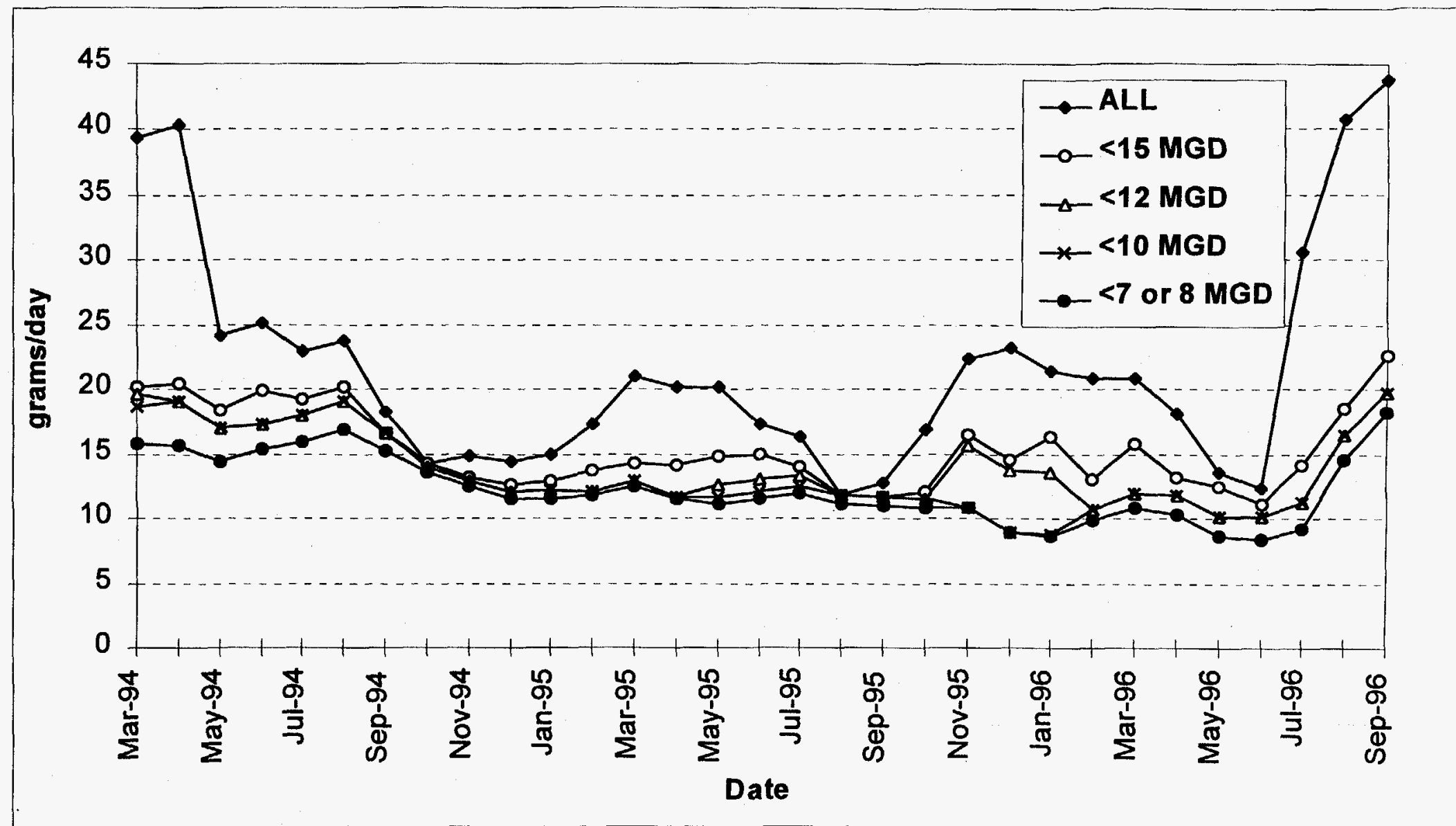

Fig. 3.9. Running 3-month average mercury loading (grams/day) at Station 17 (9422-1) for all flows and for flows greater than 7 (or 8), 10, 12, and 15 MGD excluded from the average. Figure covers period from March 1994 through September 1996. Flows greater than 8 MGD (instead of 7 MGD) are excluded from the average for August and September 1996 since baseflow after the initiation of raw water addition in late July is greater than 7 MGD. 
for total mercury. Collection of samples was discontinued when weather conditions caused freezing of the sample line extending over the stream. Average total mercury concentrations in the 24- $h$ composite samples collected by both the BMP sampler and the ER sampler were $1.07 \mu \mathrm{g} / \mathrm{L}$ and 1.04 $\mu \mathrm{g} / \mathrm{L}$, respectively. A Student's t-test of the paired sample means confirmed that the means were not significantly different. In addition, a non-parametric comparison of the paired values revealed no trends. Complete analytical results from this study are given below in Table 3.3.

Table 3.3 Mercury results from comparison study of composite samplers at Station 17

\begin{tabular}{cccc}
\hline Date & Time & $\begin{array}{c}\text { BMP Sampler } \\
\text { Hg Concentration }(\mu \mathrm{g} / \mathrm{L})\end{array}$ & $\begin{array}{c}\text { ER Sampler } \\
\text { Hg Concentration }(\mu \mathrm{g} / \mathrm{L})\end{array}$ \\
\hline 18Jan96 & $09: 40: 00$ & 0.77 & 0.61 \\
19Jan96 & $09: 15: 00$ & 4.0 & 4.6 \\
30Jan96 & $09: 35: 00$ & 0.54 & 0.58 \\
31Jan96 & $09: 30: 00$ & 0.68 & 0.66 \\
01Feb96 & $09: 40: 00$ & 0.59 & 0.64 \\
20Feb96 & $10: 50: 00$ & 1.3 & 0.6 \\
21Feb96 & $10: 00: 00$ & 0.61 & 0.68 \\
22Feb96 & $10: 25: 00$ & 0.54 & 0.44 \\
23Feb96 & $10: 10: 00$ & 0.61 & 0.57 \\
\hline & & 1.07 & 1.04 \\
\hline
\end{tabular}

\subsubsection{Catch Basins Upstream of Outfalls 163 and 169}

Over the last several months of FY96, an attempt has been made to isolate sources of Hg-contaminated water to Outfalls 163 and 169 by sampling the upstream storm drains. Catch basins, often located at the convergence of two or more major drain lines, offered access to the subsurface lines and provided a convenient location for collecting water samples from lines draining several different areas from and around Bldgs. 9204-4, 9201-4, and 9201-5, as well as around other buildings in the vicinity of the outfalls.

Water samples were collected from each flowing pipe emptying into a catch basin using a sample grab jar dedicated to that pipe. An estimated flow was recorded for each pipe sampled to estimate $\mathrm{Hg}$ loading for the pipe at the time of sampling. By starting at each outfall and sampling backwards (i.e., upstream to each accessible major convergence of the drainage system), the upstream drainage system contributing loading to each outfall was traced.

Outfall 160 and catch basins upstream of it, which drain an area south of Bldg. 9201-4, had been sampled in 1995 prior to building sump reroutes and were not resampled in this recent effort. The drainage system upstream of Outfall 160 is relatively simple and was found to be contributing $\leq 0.8 \mathrm{~g} /$ day to the outfall, at least during dry weather conditions. Thus, sampling efforts were concentrated on drainage systems upstream of Outfalls 163 and 169 since there were many unanswered questions concerning the source of $\mathrm{Hg}$ loading at these outfalls. For example, even after sump water reroutes had diverted $\mathrm{Hg}$-contaminated water from Outfall 163 to Outfall $160, \mathrm{Hg}$ loading at Outfall 163 remained $\sim 2 \mathrm{~g} /$ day indicating other sources of $\mathrm{Hg}$-contaminated water. 
Fig. 3.10 is a schematic of the drainage system and selected catch basins associated with Outfalls 160 and 163. Sampling of drain lines emptying into catch basins D-3005, D-3100, D-3101, D-3232, D-3234, and D-3311 upstream of Outfall 163 was conducted in June and September 1996. Preliminary evaluation of the results of this sampling indicate that the west, east, and northeast lines entering catch basin D-3232 are contributing a total of $\sim 0.4$ g/day of mercury to Outfall 163 . Calculations of loading for the north line entering the downstream catch basin D-3234 agree with the total loading at the upstream basin D-3232. Flow and loading are doubled to approximately $0.8 \mathrm{~g} /$ day, however, at D-3311, indicating either instream sources of mercury or additions of contaminated water from drain lines entering the main trunk line between D-3234 and D-3311. Approximately $1 \mathrm{~g} /$ day of $\mathrm{Hg}$ loading is still unaccounted for and suggests that there are other sources of mercury downstream of D-3311 or that loading is, perhaps, being overestimated at Outfall 163 because of flow measurement errors. A reevaluation of flow monitoring at this site will be conducted during December 1996.

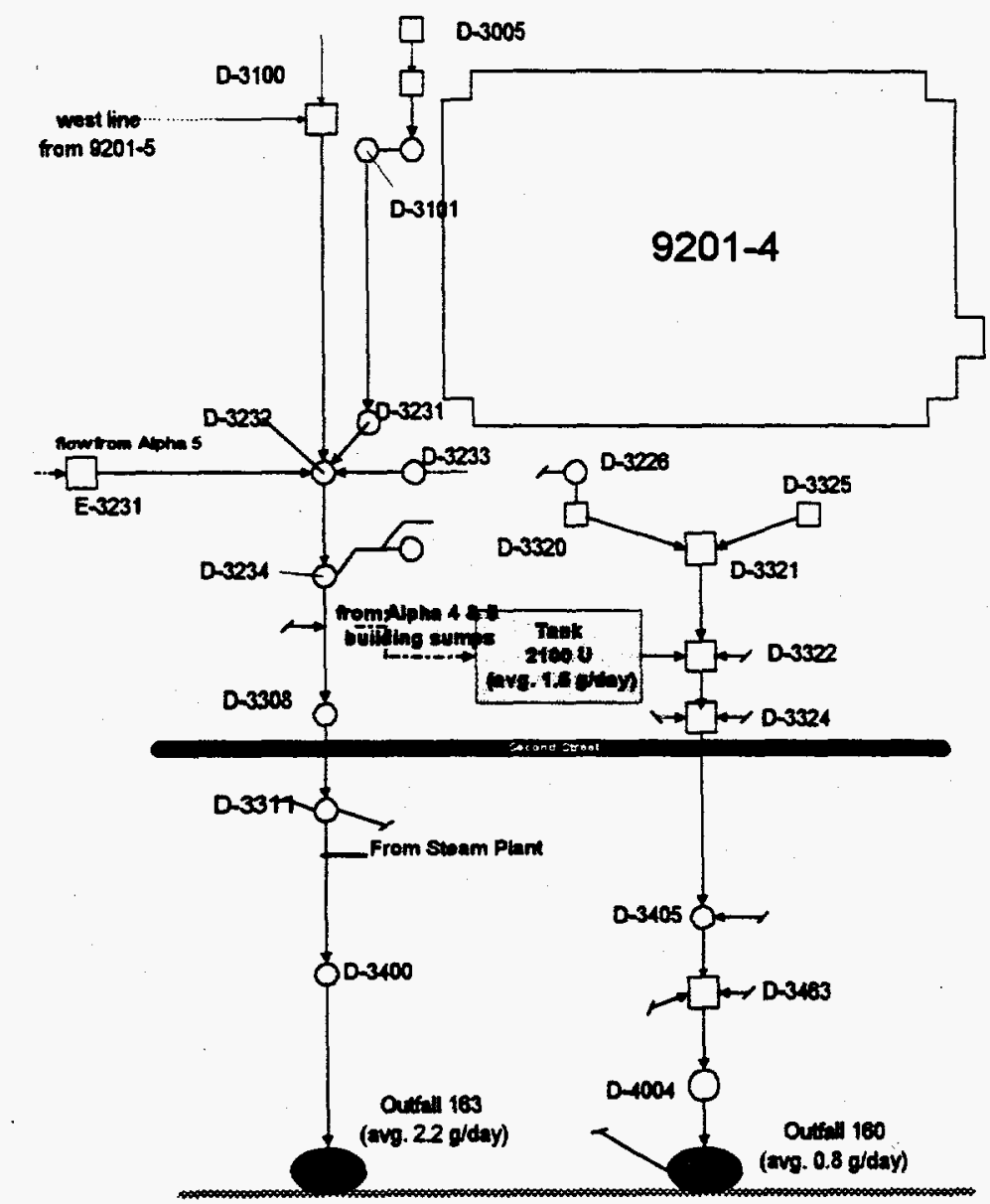

Fig. 3.10. Schematic of catch basins and storm drains upstream of Outfalls 160 and 163. Figure does not include all drainage structures associated with these outfalls nor is it to scale.

Monthly sampling results for $9422-15$ and $9422-16$ and results for storm drains discharging to Outfall 169 indicated that the lines draining areas south and east of Bldg. 9204-4 (see Fig. 3.11) contribute only $\sim 0.5 \mathrm{~g} /$ day to the loading at this outfall during dry weather. The remainder of the 
loading was traced to a major line draining the area south of Bldg. 9201-5. Grab and 24-h composite samples collected from the north line emptying into catch basin E-3250 had $\mathrm{Hg}$ concentrations ranging from 30 to $190 \mu \mathrm{g} / \mathrm{L}$ with loadings from 1.5 to $12 \mathrm{~g} /$ day (see Appendix B) easily accounting for the remainder of the loading measured at Outfall 169. In addition, $\mathrm{Hg}$ concentration on total suspended solids (TSS) collected from two storm samples from this site was 2300 and $6800 \mu \mathrm{g} / \mathrm{g}$. Since dry weather flow from the north pipe is usually $<10 \mathrm{gpm}$, plans to route this water to the CMTS are being developed. In addition, a small flume and flow monitor have recently been installed in the pipe to provide information on the range of flow during storms. During the installation of the flume, visible $\mathrm{Hg}$ was seen in the pipes to E-3250 by staff of EMD.

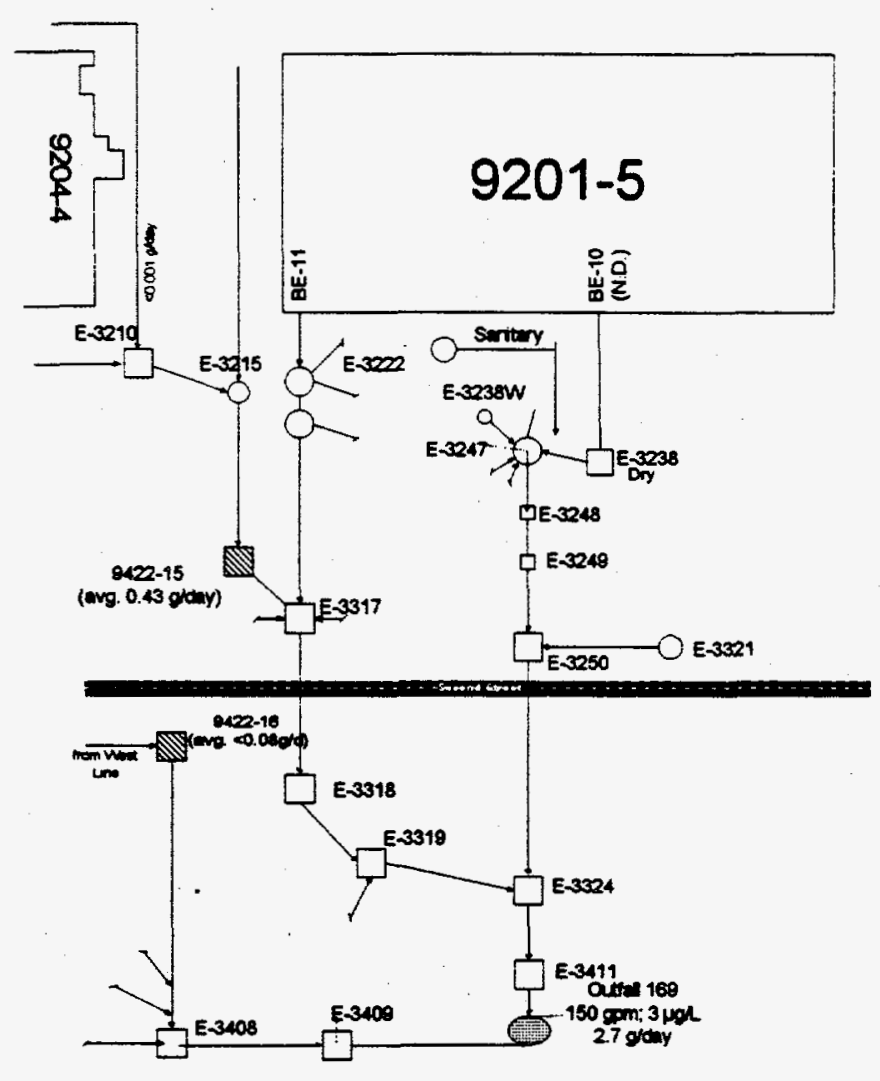

Fig. 3.11. Schematic of catch basins and storm drains upstream of Outfall 169. The figure is not to scale nor representative of all drainage structures.

\subsection{MODELING OF THE HYDROLOGIC TRANSPORT OF MERCURY IN THE UEFPC WATERSHED}

This study evolved from the Oak Ridge Y-12 Plant's requirement to comply with the NPDES permit. The permit will limit mercury loads to $5 \mathrm{~g}$ per day after December 31,1998 , for water leaving the Y-12 Plant at Station 17 (9422-1) based on average daily values for a 3-month period to reduce the exposure risk to humans, animals and aquatic life. The NPDES permit allows mercury loads produced from flows greater than 15 MGD to be excluded from the calculations. Storm event flows frequently exceed $15 \mathrm{MGD}$ and are capable of producing plant-wide mercury loadings of hundreds 
of grams from NPDES Category I, II, III and other outfall pipes; contaminated sediment in the streambed; and watershed surface area sources.

Because of this NPDES requirement, a hydrologic tool is needed to help predict storm event mercury loads from the Y-12 Plant for different assumed management practices and modifications applied to the stream, storage facilities, and watershed areas. For this reason, a hydrologic/mercury transport model was developed and calibrated for the $1.8 \mathrm{mile}^{2}$ UEFPC watershed and 1.6-mile-long UEFPC stream above Station 17, the stream gaging and water quality monitoring site at the Plant boundary. The Stormwater Management Model (SWMM) was chosen as an appropriate computer model for simulating both hydrologic flows and mercury transport loading. The model was calibrated using hydrologic and water quality data observed during the passing of the Hurricane Opal storm event in October 1995. The model was then verified using data gathered from a second storm that occurred in March 1996.

Using only rainfall data as input, the current calibrated SWMM model is able to predict water runoff volumes within a $4 \%$ margin of error and mercury loadings within a $5 \%$ error at reliable stream gaging sites. These uncertainty estimates are based on comparison between observed and simulated data for both the calibration and verification storm events. The model is now capable of simulating both real and hypothetical storm events to predict hydrographs and runoff volume for assumed land use and land management practices in the Y-12 Plant segment of the UEFPC watershed.

Based on observations taken during two storm events, Lake Reality is undoubtedly trapping mercury. During the October 1995 storm, observed mercury loading just upstream from Lake Reality was $660 \mathrm{~g}$, while the loading just downstream from Lake Reality was only $330 \mathrm{~g}$, a reduction of $50 \%$. Simulated loadings and reduction were nearly the same. Lake Reality was determined, through observation and simulation, to reduce the mercury loading for the smaller March 1996 storm event by about $70 \%$.

\subsection{EVALUATION OF STREAMBED SEDIMENTS}

The SWWM model discussed above is not presently capable of simulating deposition and resuspension of mercury in the channel of UEFPC. Further work is in progress and requires characterization of the UEFPC channel sediments. To characterize the sediments, representative streambed sediment samples were obtained approximately every $200 \mathrm{ft}$ in both the 1.4-mile- long upper natural and concrete-lined reaches of the channel upstream from Lake Reality and in the lower 0.2-mile reach below Lake Reality, but above Station 17.

Grain size analysis of the bed sediment showed that the median $\left(d_{50}\right)$ particle size generally decreased from the steeper, upper end of the UEFPC channel at the N/S Pipe (Outfall 200) to the flatter, lower concrete distribution channel to Lake Reality. The inference here is that the finer particles are being transported from the upper to the lower reaches of the stream, where sediment becomes trapped at least temporarily in the distribution channel to Lake Reality. The $d_{50}$ size (median) ranged from about $7 \mathrm{~mm}$ in the upper natural reaches to about $1 \mathrm{~mm}$ in the lower concrete distribution channel. The sediment size in the natural channel between Lake Reality and Station 17 measured approximately the same size as the sediment in the upper reaches of UEFPC. Approximately 20 to $30 \%$ of the sediment in the upper natural reach was sand-size $(2 \mathrm{~mm}$ or $2000 \mu \mathrm{m})$ or smaller, but almost $70 \%$ of the total sediment in the lower distribution channel to Lake Reality was sand-size or smaller. 
Laboratory analysis of mercury concentrations in the streambed sediment fraction with particle size $<2 \mathrm{~mm}$ demonstrated the important relationship of sediment size and mercury concentration within the channel bed. Results showed that mercury concentration typically increased with decreasing particle size for the clay/silt/sand sediment classes in UEFPC. Figure 3.12 demonstrates this relationship for sediment collected at the upper end of the natural streambed, just downstream of the N/S Pipe (Outfall 200).

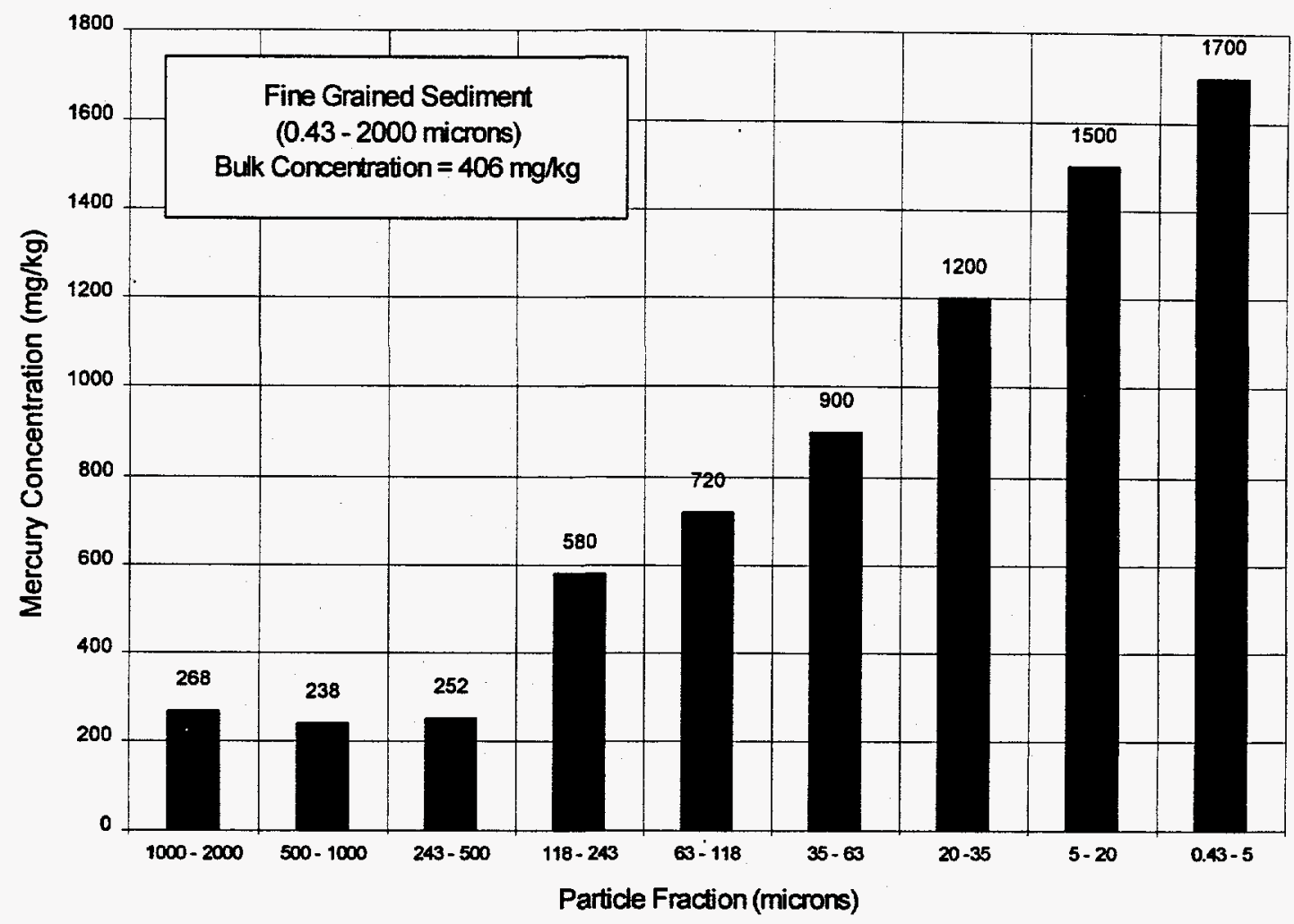

Fig. 3.12. Variation of mercury concentration with sediment particle size class at the upper end of Upper East Fork Creek natural channel.

Mercury concentrations for the clay size particles (less than $5 \mu \mathrm{m}$ ) ranged from about 125 to $1700 \mathrm{mg} / \mathrm{kg}$ (ppm) over the UEFPC streambed reach upstream from Lake Reality, while concentrations for the very coarse sand particles (1000 to $2000 \mu \mathrm{m})$ ranged from only 18 to $180 \mathrm{mg} / \mathrm{kg}$ over the same reach. Concentration of mercury in sediment samples collected in Lake Reality averaged about $150 \mathrm{mg} / \mathrm{kg}$ and ranged from $180 \mathrm{mg} / \mathrm{kg}$ for coarse sand to $140 \mathrm{mg} / \mathrm{kg}$ for clay particle sizes. Streambed mercury concentrations tended to be much lower in the short reach below Lake Reality and ranged from only $6 \mathrm{mg} / \mathrm{kg}$ for very coarse sand to $92 \mathrm{mg} / \mathrm{kg}$ for clay. "Bulk" sediment samples, representing composite clay/silt/sand particles, showed that the composite sample mercury concentration varied from about 45 to $410 \mathrm{mg} / \mathrm{kg}$ for the upper UEFPC streambed and only $23 \mathrm{mg} / \mathrm{kg}$ for the 0.2 mile reach below Lake Reality.

Figure 3.13 shows how the bulk mercury concentration varied in the UEFPC streambed from the upper end of the natural channel (Station 68+13) to, in, and downstream from Lake Reality. The high value $(251 \mathrm{mg} / \mathrm{kg}$ ) at reach $36+00$ to $44+00$ (see Fig. 3.13) is likely associated with known mercury inputs immediately upstream of this reach (i.e., Outfall 51 with $\mathrm{Hg}$ loadings of approximately $2 \mathrm{~g}$ /day). 
The sediment characterization study has shown that the UEFPC streambed contains sediment with significant concentrations of mercury, which is subject to downstream transport.

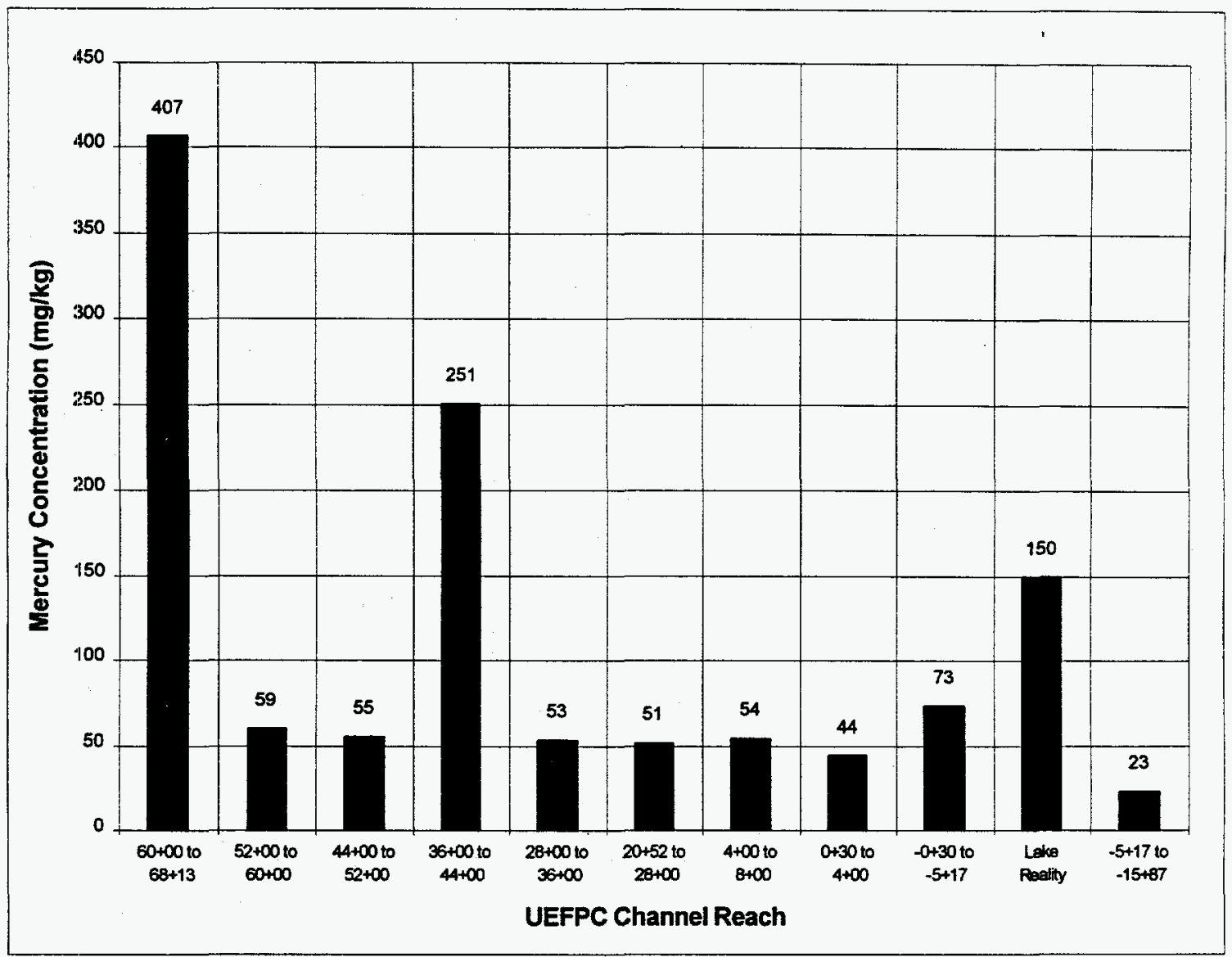

Fig. 3.13. Variation of bulk mercury concentration for sand/silt/clay classes in UEFPC streambed. 


\section{LONGITUDINAL DISTRIBUTION OF MERCURY AND MERCURY SPECIATION IN EAST FORK POPLAR CREEK}

The semiannual monitoring of waterborne mercury and methylmercury along the length of EFPC was initiated in July 1995 and continued through 1996. Tables 4.1 and 4.2 present complete results of the November 1995 and May 1996 surveys: Figs. 4.1 and 4.2 present selected results. Previous studies have indicated that baseflow concentrations of total waterborne mercury in EFPC downstream from the Y-12 Plant decrease in approximate proportion to the increase in flow that occurs as downstream water sources contribute to additional streamflow. This pattern was observed again in the 1995-1996 sampling (Tables 4.1, 4.2, Figs. 4.1, 4.2).

In May 1996, the pattern of downstream dilution of waterbome mercury was not observed at sites in the lower half of the creek because of residual $\mathrm{Hg}$-contaminated suspended solids from a recent rain (Table 4.2). These data indicate that total mercury concentrations in EFPC water under baseflow conditions continue to reflect chronic inputs of mercury from the Y-12 Plant, rather than inputs of additional mercury from contaminated soils and sediments in the floodplain. Thus, reductions in mercury releases from the Y-12 Plant are expected to result in reductions in baseflow total mercury concentrations in water throughout EFPC.

The longitudinal pattern of dissolved mercury in EFPC is similar to that exhibited by total mercury, but is more pronounced because of the conversion of dissolved mercury to particle-associated forms in the uppermost reaches of the stream. Mercury enters EFPC in its upper reaches as dissolved mercury, reflecting the nature of the sources and effects of residual chlorine in the storm drain system (Figs. 4.1-4.3). Where the creek emerges at the N/S Pipe, 85 to $95 \%$ of the total mercury is in dissolved form. That mercury is rapidly transformed to particle-associated forms in the reach above and in Lake Reality and constitutes about $5 \%$ of the total mercury in EFPC exiting Lake Reality. Much of the dissolved mercury in EFPC at the N/S Pipe is readily reduced by trace concentrations of stannous chloride (Table 4.2), suggesting that in situ reduction at the N/S Pipe followed by natural downstream volatilization of elemental mercury may remove some of the mercury remaining in EFPC after point sources have been remediated.

The role of Lake Reality as a source of both total mercury and methylmercury was highlighted in the 1995 Mercury Abatement Report (Y/ER-251), and results of subsequent sampling continue to confirm the importance of Lake Reality in that role. In the 1995 and 1996 sampling, total mercury concentration in water exiting Lake Reality exceeded that in water entering Lake Reality by two to two-and-a-half times and methylmercury concentrations below Lake Reality were three to four times higher than in the influent water (Figs. 4.1-4.3). For both methylmercury and total mercury, the increase across Lake Reality is due to particle-associated forms.

Two major actions that occurred in 1996 should greatly affect longitudinal mercury profiles in EFPC. Flow Management, which started in late July 1996, maintains flow at a minimum of 7 MGD at the Y-12 Plant boundary. This additional water from the Clinch River dilutes mercury in upper EFPC by more than twofold, decreases the retention time in Lake Reality, contributes uncontaminated particulate matter, and lowers stream temperature. Results of the September 1996 sampling (Fig. 4.3, Table 4.3) indicate that Lake Reality continues to function as a source of both total mercury and methylmercury under baseflow conditions. The experimental Lake Reality bypass, scheduled to start in November 1996, will eliminate the contribution of Lake Reality to downstream methylmercury and total mercury concentrations. The combination of these two actions is expected to reduce typical mercury and methylmercury concentrations in EFPC at the Y-12 boundary by more than $50 \%$. 
Table 4.1 Results of longitudinal sampling of EFPC conducted November 27, 1995. Letters " $A$ " and " $B$ " after sampling location indicate field duplicates

\begin{tabular}{|c|c|c|c|c|c|c|c|c|c|c|c|}
\hline \multicolumn{2}{|c|}{$\begin{array}{c}\text { EFPC } \\
\text { Sampling location distance }(\mathrm{km})\end{array}$} & \multirow{2}{*}{$\frac{\text { Time }}{13: 00}$} & \multirow{2}{*}{$\frac{\operatorname{Temp}\left({ }^{\circ} \mathrm{C}\right)}{9.0}$} & \multirow{2}{*}{$\begin{array}{c}\begin{array}{c}\text { Conductance } \\
\mu \mathrm{S} / \mathrm{cm}\end{array} \\
260\end{array}$} & \multirow{2}{*}{$\frac{\begin{array}{c}\mathrm{TSS} \\
(\mathrm{mg} / \mathrm{L})\end{array}}{0.36}$} & \multirow{2}{*}{$\begin{array}{c}\begin{array}{c}\mathrm{Hg} \text { total } \\
(\mu \mathrm{g} / \mathrm{L})\end{array} \\
0.002\end{array}$} & \multirow{2}{*}{$\frac{\begin{array}{c}\mathrm{Hg} \text { diss. } \\
(\mu \mathrm{g} / \mathrm{L})\end{array}}{0.006}$} & \multirow{2}{*}{$\begin{array}{c}\begin{array}{c}\mathrm{MeHg} \\
\text { total } \\
\text { (ng/L) }\end{array} \\
0.029\end{array}$} & \multirow{2}{*}{$\begin{array}{c}\begin{array}{c}\mathrm{MeHg} \\
\text { diss. } \\
\text { (ng/L) }\end{array} \\
0.040\end{array}$} & \multirow{2}{*}{$\frac{\% \text { Diss. } \mathrm{Hg}}{260.6}$} & \multirow{2}{*}{$\begin{array}{c}\begin{array}{c}\text { Particulate } \mathrm{Hg} \\
\mu \mathrm{g} / \mathrm{g}\end{array} \\
-11\end{array}$} \\
\hline BCK 0.6 & $\mathrm{~N} / \mathrm{A}$ & & & & & & & & & & \\
\hline EFPC 2.1 & 2.1 & $13: 28$ & 9.5 & 295 & 1.39 & 0.056 & 0.010 & 0.306 & 0.344 & 18.1 & 33 \\
\hline EFPC $6.3 \mathrm{~A}$ & 6.3 & $14: 05$ & 10.9 & 348 & 1.57 & 0.082 & 0.015 & 0.560 & 0.430 & 18.3 & 43 \\
\hline EFPC 6.3 B & 6.3 & $14: 05$ & 10.9 & 348 & 1.56 & 0.071 & 0.025 & 0.561 & 0.437 & 35.3 & 29 \\
\hline EFPC 13.8 & 13.8 & $14: 35$ & 9.3 & 273 & 1.31 & 0.132 & 0.021 & 0.207 & 0.201 & 16.0 & 85 \\
\hline EFPC 18.2 & 18.2 & $14: 55$ & 11.8 & 275 & 1.28 & 0.166 & 0.024 & 0.118 & 0.108 & 14.2 & 111 \\
\hline EFPC 20.8 & 20.8 & $15: 10$ & 12.9 & 301 & 0.74 & 0.160 & 0.038 & 0.175 & 0.306 & 23.8 & 165 \\
\hline NOAA & 22.0 & $15: 25$ & 13.5 & 302 & 0.74 & 0.284 & 0.066 & 0.204 & 0.101 & 23.1 & 296 \\
\hline EFPC 23.4 & 23.4 & $15: 45$ & 14.2 & 302 & 6.99 & 1.547 & 0.100 & 0.562 & 0.088 & 6.4 & 207 \\
\hline RL-IN & 23.5 & $16: 05$ & 17.4 & 333 & 0.92 & 0.602 & 0.265 & 0.182 & 0.085 & 44.0 & 366 \\
\hline EFPC 24.8 & 24.8 & $16: 25$ & 19.0 & 375 & 0.93 & 1.103 & 0.708 & 0.132 & 0.087 & 64.2 & 423 \\
\hline Station 8 & 25.0 & $16: 45$ & 20.0 & 580 & 1.31 & 1.208 & 0.594 & 0.168 & 0.105 & 49.2 & 470 \\
\hline N/S Pipe A & 26.0 & $17: 00$ & 21.5 & 700 & 1.65 & 2.169 & 2.209 & 0.398 & 0.193 & 101.8 & -24 \\
\hline N/S Pipe B & 26.0 & $17: 05$ & 21.8 & 690 & 1.54 & 1.555 & 1.434 & 0.353 & 0.207 & 92.2 & 79 \\
\hline Hinds Creek & N/A & $14: 55$ & 9.0 & 130 & 3.03 & $>0.095$ & 0.018 & 0.032 & 0.015 & - & - \\
\hline
\end{tabular}

Diss. $=$ dissolved

RL-IN = Lake Reality Inlet

NOAA = National Oceanic and Atmospheric Administration

$\mathrm{BCK}=\mathrm{Bear}$ Creek kilometer 
Table 4.2 Results of longitudinal sampling of EFPC conducted May 31, 1996. (Letters "A" and "B" after sampling location indicate field duplicates)

\begin{tabular}{|c|c|c|c|c|c|c|c|c|c|c|c|c|c|}
\hline $\begin{array}{l}\text { Sampling } \\
\text { location }\end{array}$ & Time & $\begin{array}{c}\text { Distance } \\
(\mathrm{km})\end{array}$ & $\begin{array}{l}\text { Temp. } \\
\left({ }^{\circ} \mathrm{C}\right)\end{array}$ & $\begin{array}{c}\text { Conductance } \\
\mu \mathrm{S} / \mathrm{cm}\end{array}$ & $\begin{array}{c}\text { TSS } \\
(\mathrm{mg} / \mathrm{L}) \\
\end{array}$ & $\begin{array}{c}\mathrm{Hg} \text { total } \\
(\mu \mathrm{g} / \mathrm{L})\end{array}$ & $\begin{array}{c}\text { Hg diss. } \\
(\mu \mathrm{g} / \mathrm{L})\end{array}$ & $\begin{array}{l}\mathrm{SnCl} 2 \mathrm{Ext} \\
\mathrm{Hg}(\mu \mathrm{g} / \mathrm{L})\end{array}$ & $\begin{array}{c}\mathrm{MeHg} \text { total } \\
(\mathrm{ng} / \mathrm{L})\end{array}$ & $\begin{array}{c}\text { MeHg diss. } \\
\text { (ng/L) }\end{array}$ & $\begin{array}{l}\mathrm{DGM} \\
(\mathrm{pg} / \mathrm{L})\end{array}$ & $\begin{array}{c}\text { \% Diss. Hg } \\
(\%)\end{array}$ & $\begin{array}{c}\text { Particulate } \mathrm{Hg} \\
\mu \mathrm{g} / \mathrm{g}\end{array}$ \\
\hline BCK 0.6 & $08: 45$ & N/A & 14.0 & 179 & 4.74 & 0.012 & 0.005 & - & 0.232 & 0.149 & 43.9 & 44.2 & 1.4 \\
\hline EFPC 2.1 & $09: 25$ & 2.1 & 15.1 & 241 & 15.91 & 0.280 & 0.006 & - & 0.838 & 0.258 & 68.9 & 2.3 & 17.2 \\
\hline EFPC 6.3 & $08: 15$ & 6.3 & 15.5 & 272 & 15.56 & 0.380 & 0.007 & - & 0.914 & 0.304 & 71.9 & 1.9 & 24.0 \\
\hline EFPC 13.8 & $10: 00$ & 13.8 & 17.1 & 290 & 7.17 & 0.290 & 0.009 & - & 0.523 & 0.240 & 134.0 & 3.2 & 39.2 \\
\hline EFPC $18.2 \mathrm{~A}$ & $10: 20$ & 18.2 & 17.5 & 316 & 2.94 & 0.134 & 0.018 & - & 0.267 & 0.139 & 234.7 & 13.3 & 39.3 \\
\hline EFPC 18.2 B & $10: 20$ & 18.2 & - & - & 3.04 & 0.155 & 0.018 & - & 0.253 & 0.142 & 265.8 & 11.7 & 45.0 \\
\hline EFPC 20.8 & $10: 40$ & 20.8 & 19.0 & 358 & 4.03 & 0.166 & 0.026 & - & 0.470 & 0.227 & 353.6 & 15.4 & 34.8 \\
\hline NOAA & 11:00 & 22.0 & 20.2 & 369 & 2.16 & 0.275 & 0.045 & - & 0.399 & 0.097 & $?$ & 16.3 & 106.5 \\
\hline EFPC 23.4 & $11: 30$ & 23.4 & 21.1 & 382 & 8.16 & 1.127 & 0.038 & 0.045 & 1.455 & 0.131 & 177.9 & 3.4 & 133.4 \\
\hline RL-IN A & $12: 25$ & 23.5 & 23.1 & 370 & 0.99 & 0.481 & 0.075 & 0.09 & 0.376 & 0.104 & 4678 & 15.5 & 410.2 \\
\hline RL-IN B & $12: 25$ & 23.5 & - & - & 0.98 & 0.432 & 0.079 & 0.06 & 0.344 & 0.104 & 4512 & 18.4 & 360.4 \\
\hline EFPC 24.8 & $13: 00$ & 24.8 & 22.5 & 360 & 0.69 & 0.771 & 0.310 & 0.26 & 0.174 & 0.109 & - & 40.2 & 668.7 \\
\hline Station 8 & $13: 20$ & 25.0 & 22.0 & 340 & 2.76 & 0.861 & 0.332 & 0.22 & 0.25 & 0.129 & - & 38.5 & 191.8 \\
\hline N/S Pipe & $16: 30$ & 26.0 & 21.0 & 365 & 1.28 & 1.127 & 0.960 & 0.85 & 0.384 & 0.360 & $?$ & 85.2 & 131.1 \\
\hline Hinds Creek & $10: 30$ & N/A & 15.0 & - & 34.46 & 0.004 & 0.001 & - & 0.095 & 0.056 & 20.5 & 31.8 & 0.1 \\
\hline
\end{tabular}

Diss. $=$ dissolved

RL-IN = Lake Reality Inlet

NOAA = National Oceanic and Atmospheric Administration

$\mathrm{BCK}=$ Bear Creek kilometer 

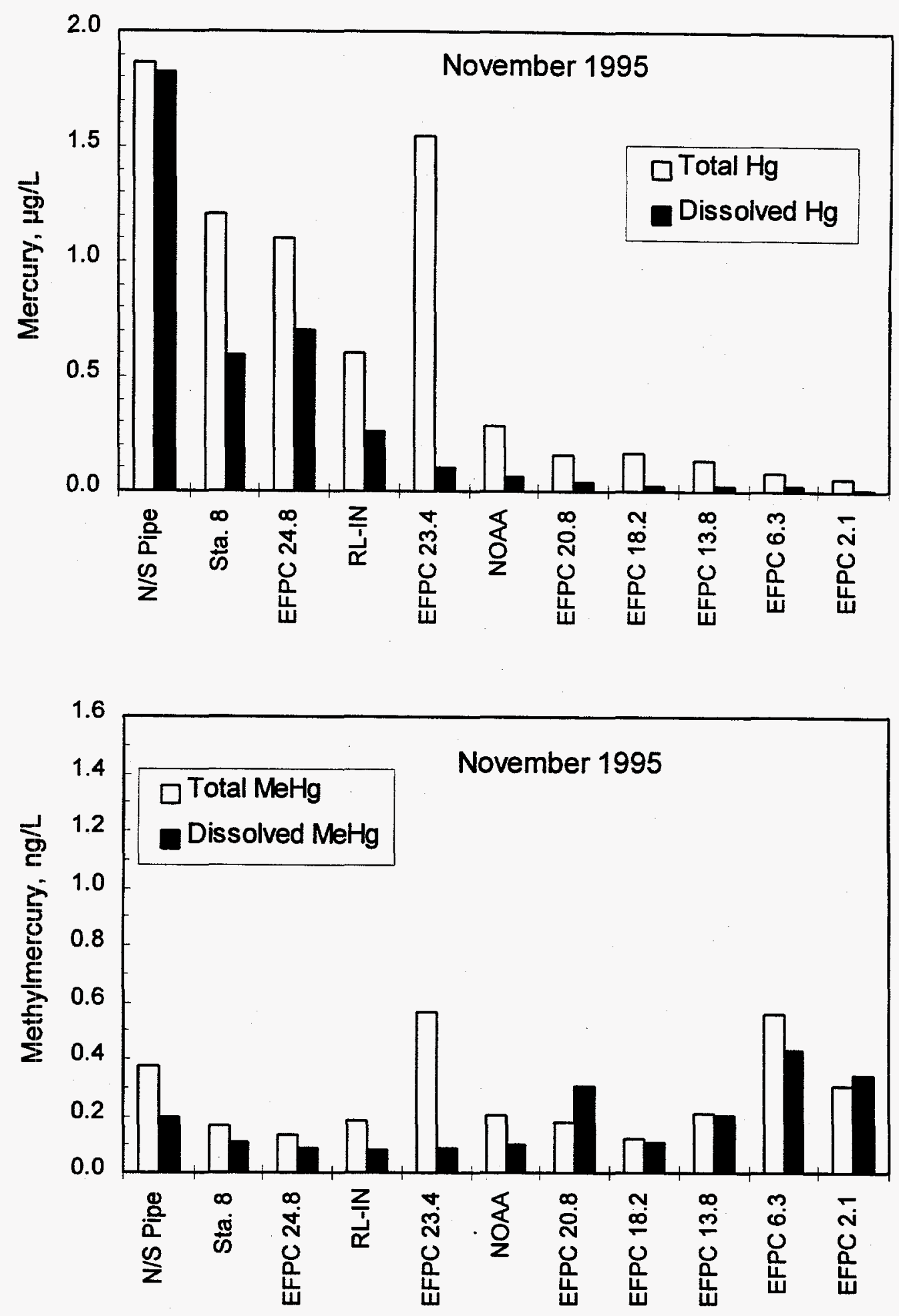

Fig. 4.1. Results of longitudinal sampling and analysis of water for total and dissolved mercury and methylmercury from East Fork Poplar Creek in November 1995. 

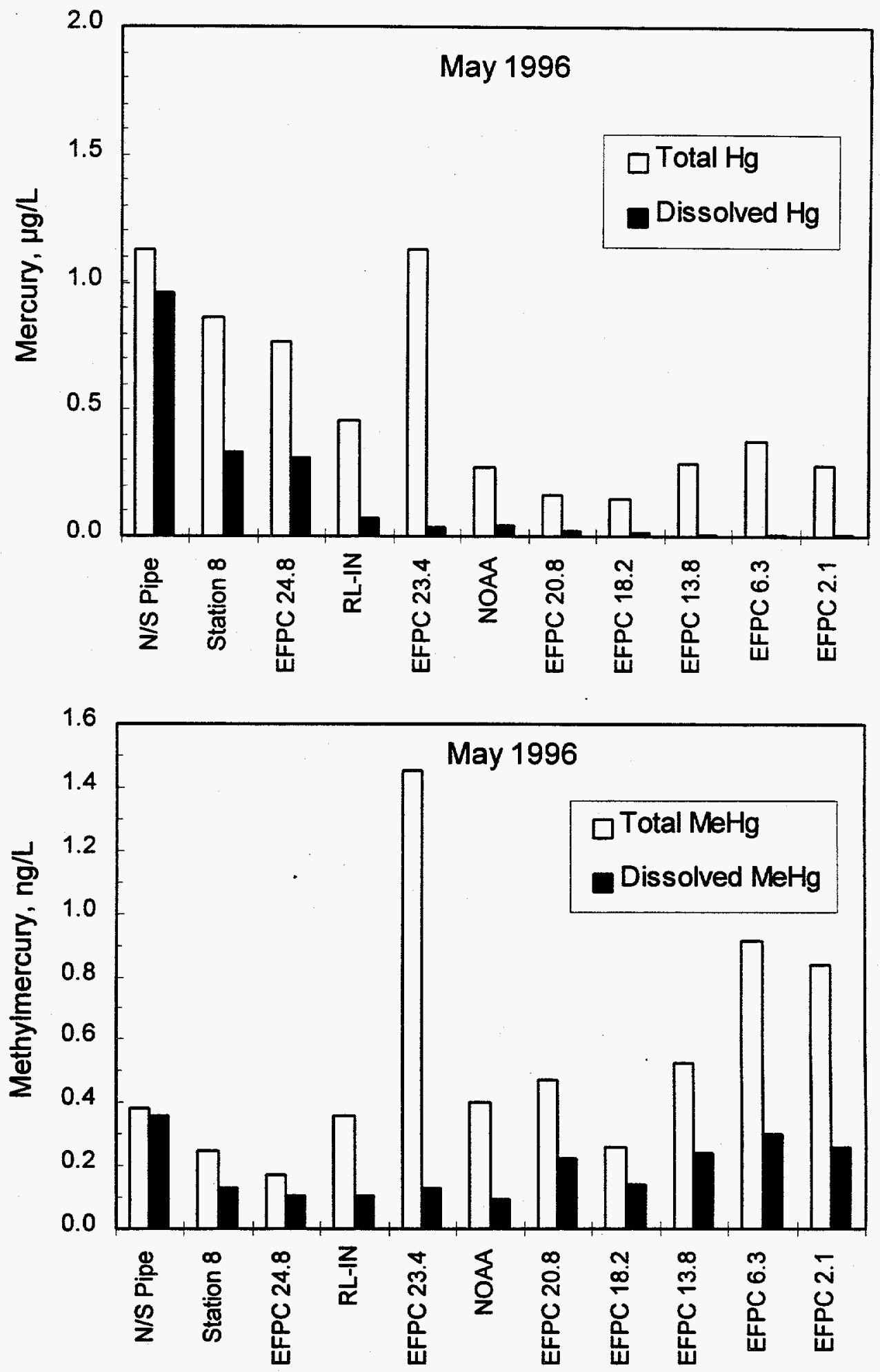

Fig. 4.2. Results of longitudinal sampling and analysis of water for total and dissolved mercury and methylmercury from East Fork Poplar Creek in May 1996. 

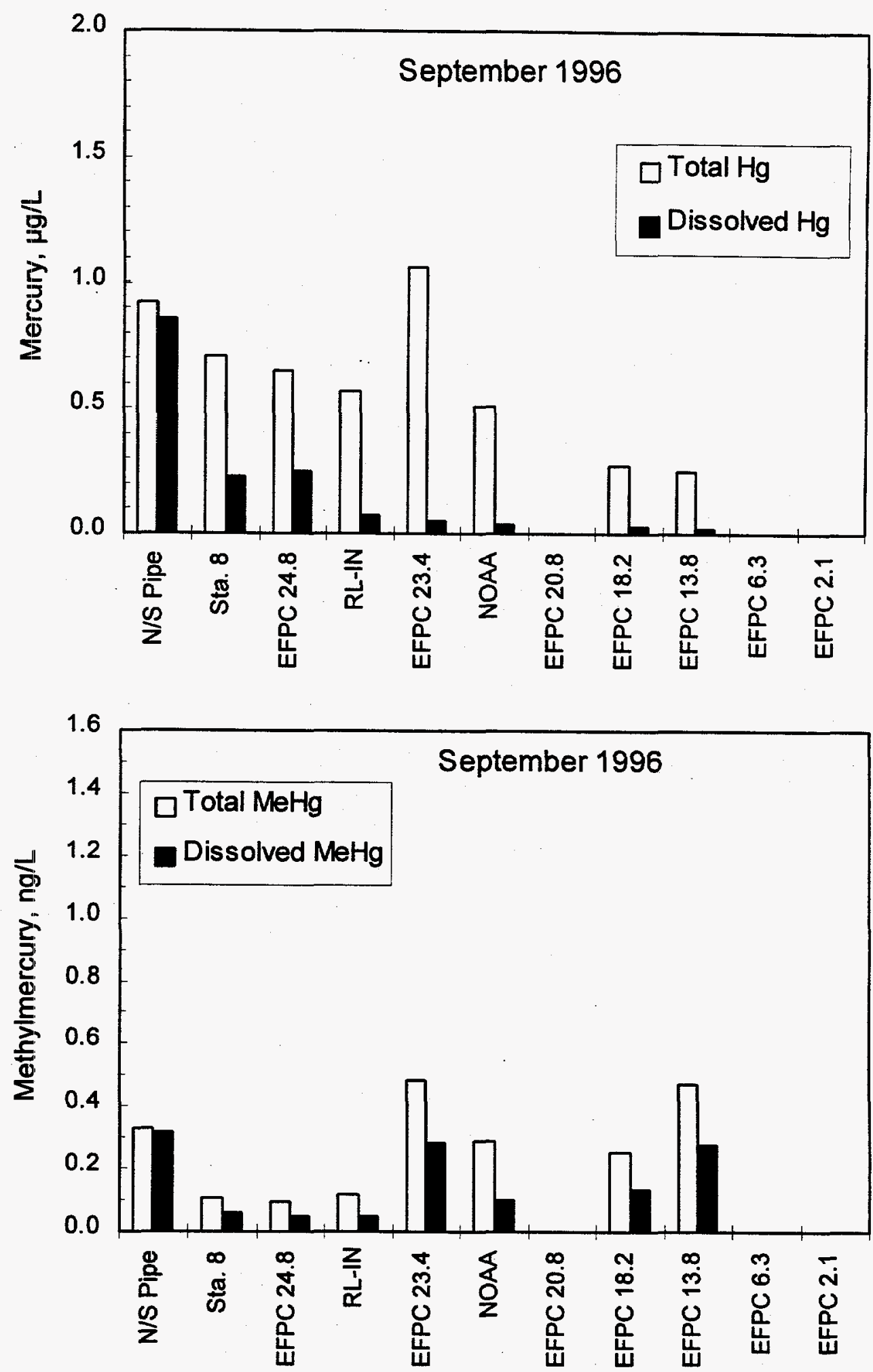

Fig. 4.3. Results of longitudinal sampling and analysis of water for total and dissolved mercury and methylmercury from East Fork Poplar Creek in September 1996. 
Table 4.3 Results of longitudinal sampling of EFPC conducted September 10, 1996

\begin{tabular}{|c|c|c|c|c|c|c|c|c|c|c|c|}
\hline $\begin{array}{l}\text { Sampling } \\
\text { Location }\end{array}$ & $\begin{array}{c}\text { EFPC } \\
\text { distance } \\
(\mathrm{km})\end{array}$ & Time & $\begin{array}{l}\text { Temp. } \\
\left({ }^{\circ} \mathrm{C}\right)\end{array}$ & $\begin{array}{c}\text { Conduc } \\
\mathrm{t} \mu / \mathrm{cm}\end{array}$ & $\begin{array}{c}\text { TSS } \\
(\mathrm{mg} / \mathrm{L})\end{array}$ & $\begin{array}{c}\text { Hg total } \\
(\mu / \mathrm{L})\end{array}$ & $\begin{array}{c}\mathrm{Hg} \\
\text { diss } \\
(\mu / \mathrm{L})\end{array}$ & $\begin{array}{c}\mathrm{MeHg} \\
\text { total } \\
(\mathrm{ng} / \mathrm{L})\end{array}$ & $\begin{array}{c}\mathrm{MeHg} \\
\text { diss } \\
\text { (ng/L) }\end{array}$ & $\begin{array}{l}\% \text { Diss } \\
\mathrm{Hg}(\%)\end{array}$ & $\begin{array}{l}\text { Particulate } \\
\mathrm{Hg}(\mu \mathrm{g} / \mathrm{g})\end{array}$ \\
\hline $\begin{array}{l}\text { EFPC } \\
13.8\end{array}$ & 13.8 & $09: 15$ & 20.5 & 320 & 6.03 & 0.253 & 0.019 & 0.470 & 0.276 & 7.6 & 38.8 \\
\hline $\begin{array}{l}\text { EFPC } \\
18.2\end{array}$ & 18.2 & $09: 45$ & 20.0 & 340 & 3.08 & 0.276 & 0.028 & 0.251 & 0.138 & 10.1 & 80.7 \\
\hline NOAA & 22.0 & $10: 20$ & 20.0 & 330 & 4.16 & 0.510 & 0.037 & 0.287 & 0.098 & 7.3 & 113.7 \\
\hline $\begin{array}{l}\text { EFPC } \\
23.4\end{array}$ & 23.4 & $09: 20$ & 20.0 & 315 & 6.61 & 1.061 & 0.049 & 0.486 & 0.285 & 4.6 & 153.2 \\
\hline RL-IN & 23.5 & $09: 40$ & 20.0 & 310 & 3.06 & 0.569 & 0.070 & 0.121 & 0.046 & 12.4 & 163.0 \\
\hline $\begin{array}{l}\text { EFPC } \\
24.8\end{array}$ & 24.8 & $10: 05$ & 19.1 & 305 & 3.76 & 0.653 & 0.249 & 0.093 & 0.049 & 38.1 & 107.4 \\
\hline Station 8 & 25.0 & $10: 20$ & 19.0 & 305 & 4.32 & 0.710 & 0.232 & 0.108 & 0.060 & 32.6 & 110.9 \\
\hline N/S Pipe & 26.0 & $11: 05$ & 23.7 & 440 & 0.69 & 0.920 & 0.853 & 0.332 & 0.321 & 92.7 & 97.6 \\
\hline $\begin{array}{l}\text { Clinch } \\
\text { River }\end{array}$ & NA & $10: 45$ & 17.0 & 265 & 6.45 & 0.001 & 0.001 & $0.015^{\mathrm{a}}$ & $0.011^{\mathrm{a}}$ & 51.4 & 0.1 \\
\hline
\end{tabular}

a Less than estimated MDL of $0.018 \mathrm{ng} / \mathrm{L}$. 


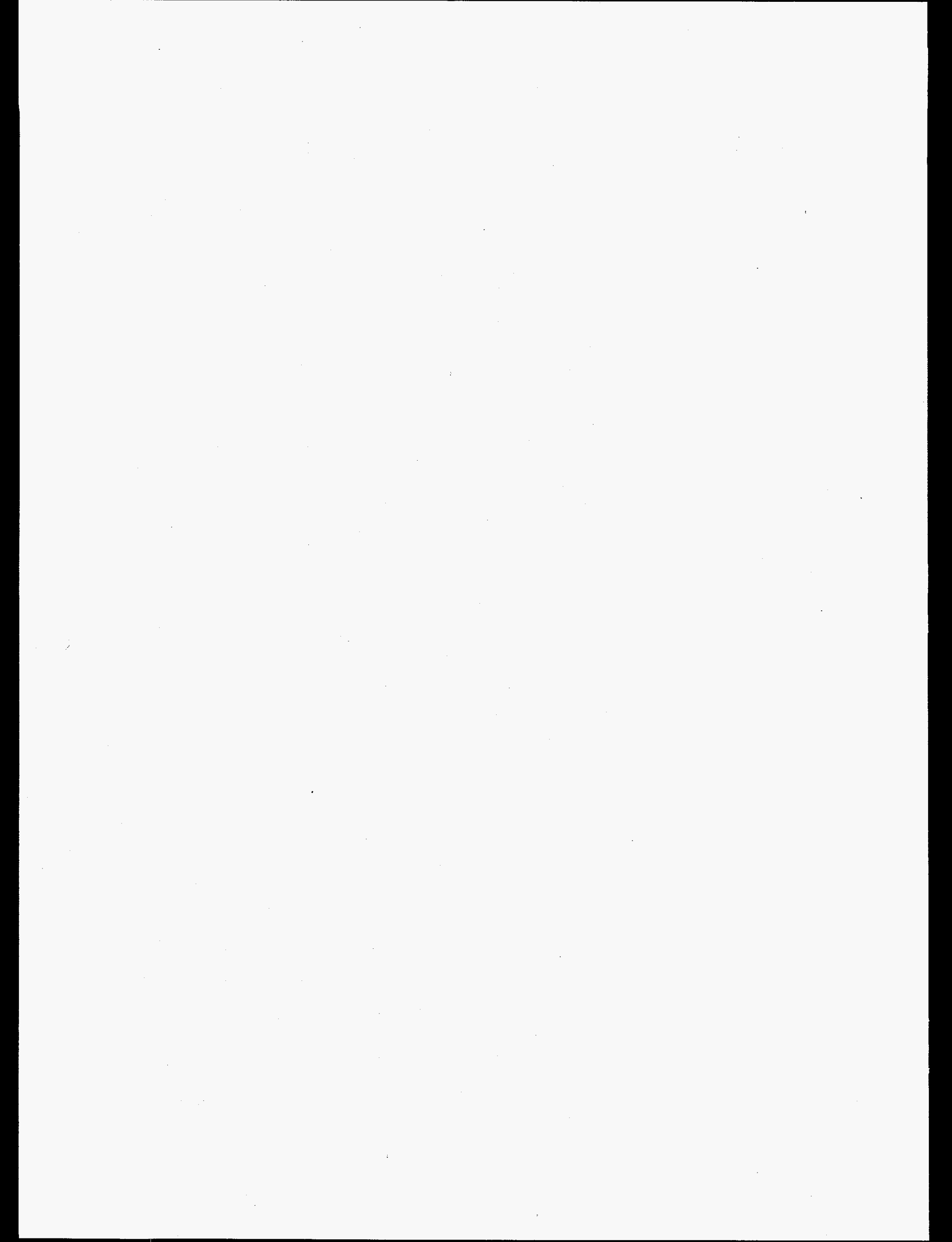




\section{BIOLOGICAL MONITORING AND ABATEMENT PROGRAM MERCURY STUDIES}

\subsection{GOALS AND OBJECTIVES}

The Biological Monitoring and Abatement Program for EFPC has been monitoring mercury concentrations in fish in EFPC since spring of 1985. Coupled with work conducted by ORNL ESD in 1982 and TVA in 1984, it provides a nearly continuous 14-year record. The objectives of the monitoring are to track changes in mercury contamination over time and distance that can be used to assess and guide remedial actions and strategies concerning aqueous discharges at the Y-12 Plant and to provide information to help the State of Tennessee implement oversight and regulation aimed at enhancing and protecting the resource value of EFPC.

\subsection{METHODS}

Redbreast sunfish are collected twice yearly at seven sites in EFPC (Fig. 5.1), from its headwaters within the Y-12 Plant to where it becomes impounded by backwaters of Watts Bar Reservoir. At each site, eight sunfish of a size large enough to be taken by sport fishermen are collected, filleted and scaled, and a sample of the fillet analyzed for total mercury. Largemouth bass, a predator fish likely to exhibit the highest degree of food chain bioaccumulation of mercury, are collected annually in Lake Reality and the 5-km reach of EFPC below the Y-12 Plant boundary. Forage fish (stonerollers and striped shiners) were collected and analyzed for total mercury and methylmercury in support of the lower EFPC remedial investigation. Measurements of mercury in water were made in conjunction with the Y-12 RMPE.

\subsection{RESULTS}

\subsubsection{Downstream Profiles of Mercury Contamination}

A summary of results of mercury monitoring in EFPC fish in FY96 is presented in Table 5.1. High mercury concentrations (approximately $2 \mathrm{mg} / \mathrm{kg}$ ) are found in fish from EFPC within the Y-12 Plant upstream from Lake Reality, where dissolved aqueous mercury concentrations are highest. As was the case in 1995, largemouth bass from Lake Reality contained mercury concentrations that were no higher than those typical of redbreast sunfish, despite being higher on the food chain. Bass from EFPC below the pond also had mercury concentrations similar to sunfish. It may be that bass in these locations feed extensively on stonerollers, an herbivorous forage fish that does not accumulate methylmercury as effectively as carnivorous species (Sect. 5.3.3).

The downstream profiles of mercury concentrations in redbreast sunfish versus distance in EFPC below the Y-12 Plant are shown in Fig. 5.2. Mean mercury concentrations in sunfish are relatively similar at all sites downstream from Lake Reality, despite decreasing concentrations of total mercury in water and sediments along the same gradient. Before New Hope Pond was replaced with Lake Reality in 1988, total mercury concentrations in EFPC redbreast sunfish decreased in a regular, consistent pattern with increasing distance below the Y-12 Plant (see Fig. 5.3). This pattern was roughly proportional to dilution of the Y-12 discharge with distance, and was interpreted as evidence of the importance of the aqueous discharge of mercury from the Y-12 Plant in determining the degree 
5-2

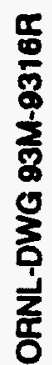

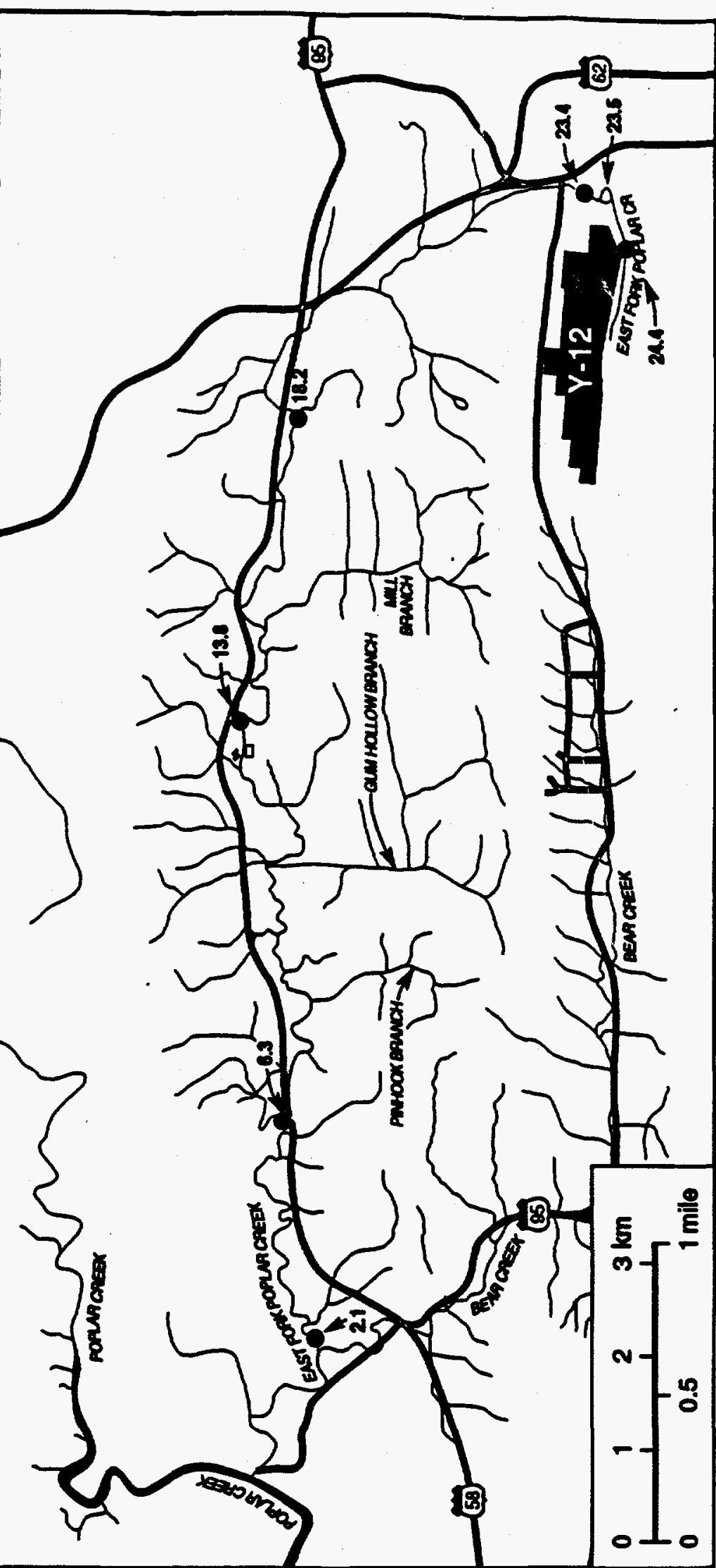

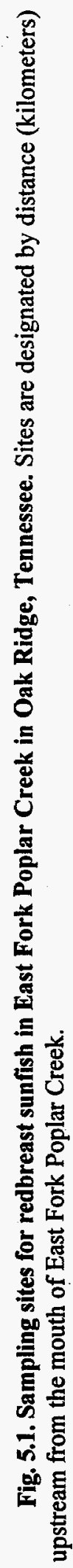


Table 5.1 Concentrations of mercury (mean $\pm \mathrm{SE}, \mathrm{mg} / \mathrm{kg}$ wet $\mathrm{wt}$.) in fillets of redbreast sunfish and largemouth bass from East Fork Poplar Creek, FY96. [The second row (in parentheses) is range, the third row is the number of fish exceeding the FDA limit $(1 \mathrm{mg} / \mathrm{kg})]$

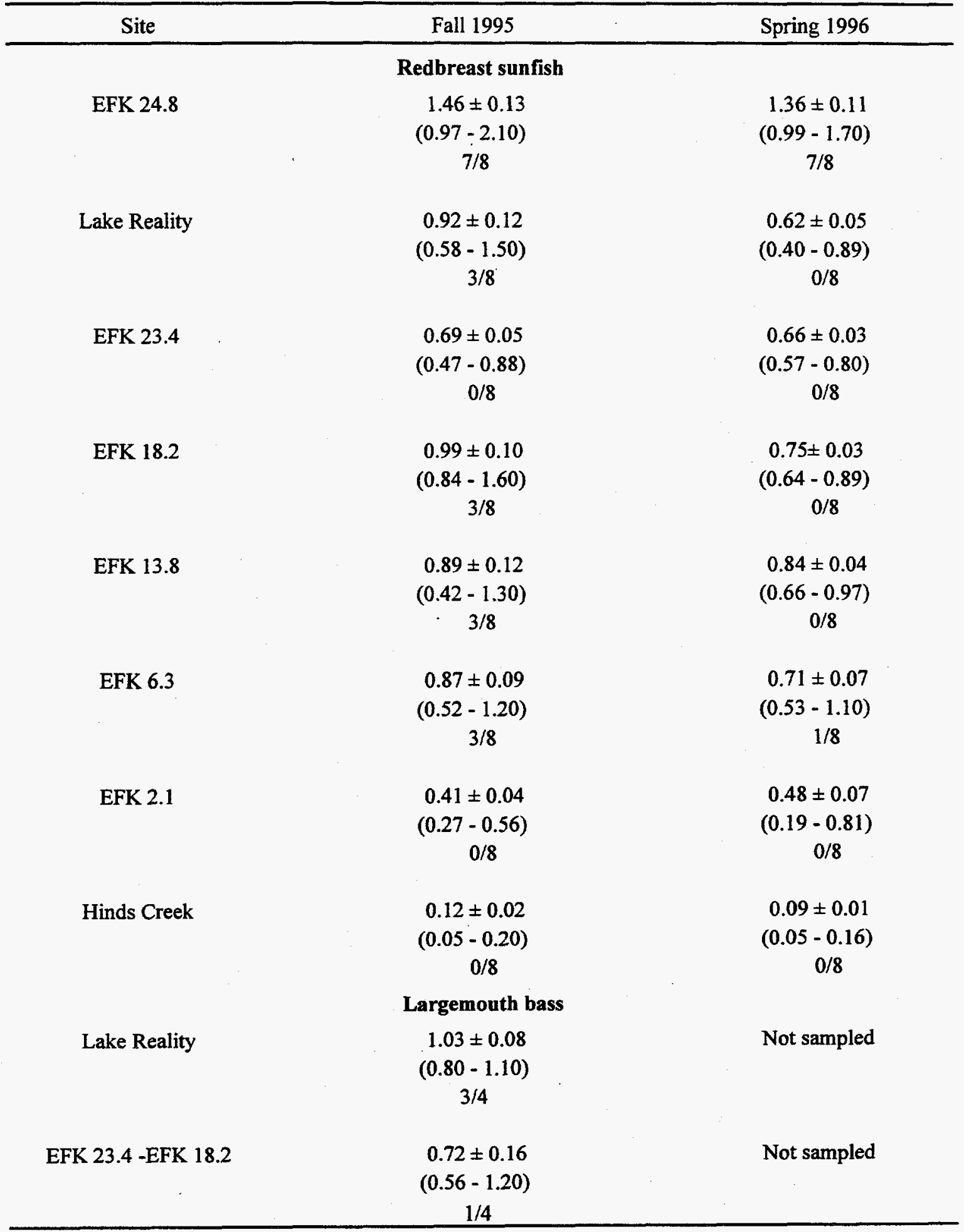



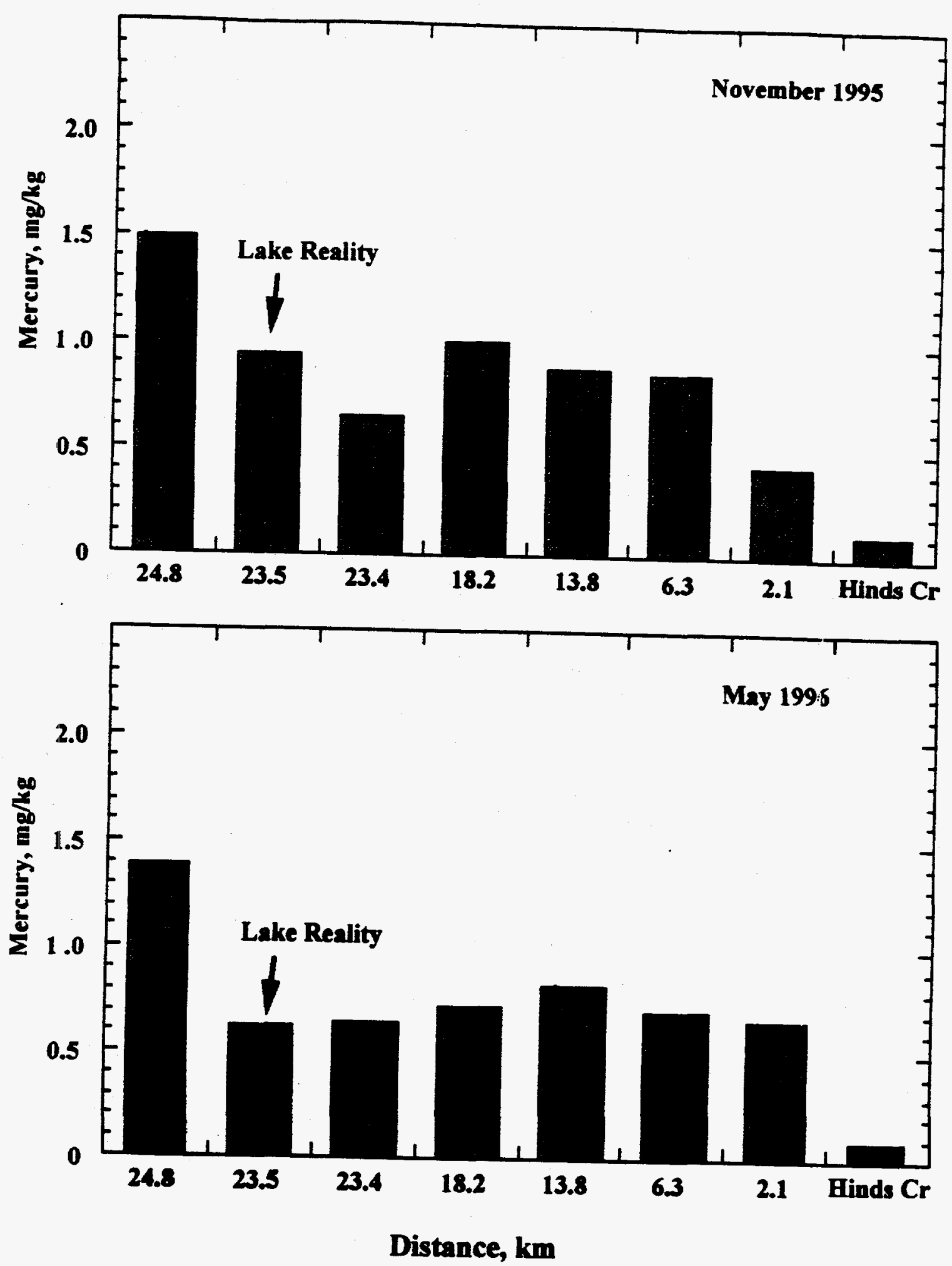

Fig. 5.2. Mean concentration of mercury in redbreast sunfish $(n=8$ fish per site) in East Fork Poplar Creek versus distance upstream from its mouth. 
of mercury contamination in EFPC fish. The longitudinal pattern seen in Fig. 5.2 has been typical since 1989, and is similar to that expected if mercury inputs to the headwaters were reduced.

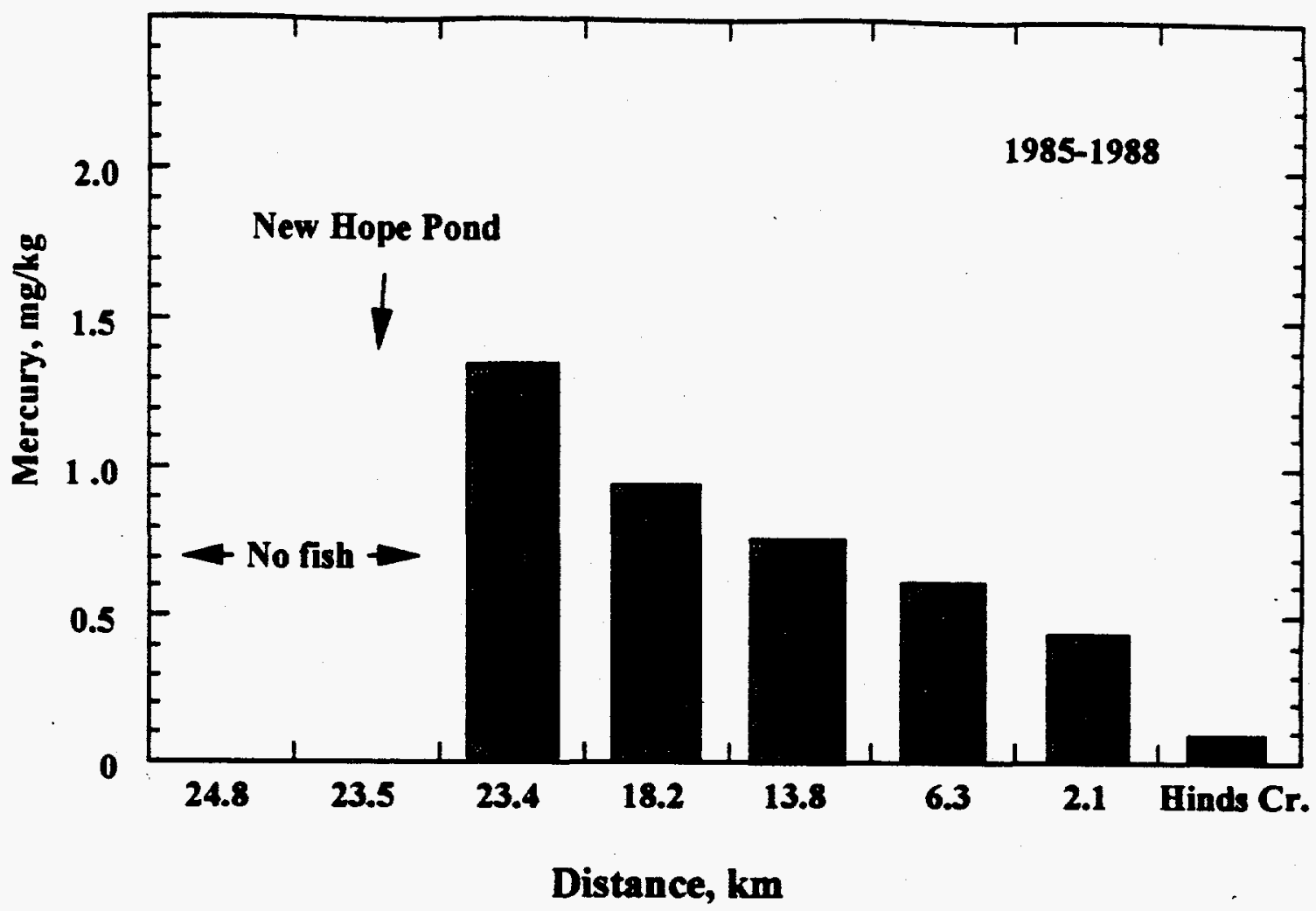

Fig. 5.3. Mean concentration of mercury in redbreast sunfish $(n=64$ fish per site) in East Fork Poplar Creek versus distance upstream from its mouth, prior to Lake Reality.

\subsubsection{Changes in Mercury Bioaccumulation over Time}

Since BMAP monitoring started in 1985, mercury concentrations in fish at East Fork kilometer (EFK) 23.4 have decreased by about 60\% (Fig. 5.4). However, at sites farther downstream (Fig. 5.5), mean mercury concentrations in redbreast sunfish have not changed appreciably over the past 11 years. In the lower portion of EFPC, mercury concentrations in sunfish have exhibited a statistically significant increasing trend over the study period (Fig. 5.6). Although the response at EFK 23.4 is roughly that expected with reduced mercury discharges from Y-12, that cannot explain the consistent pattern of increasing mercury concentrations in fish at downstream sites. If changes in mercury concentrations in fish and water at EFK 23.4 are compared over just the period of time subsequent to completion of Lake Reality, a distinctly different picture of the response to mercury discharge abatement is presented (Fig. 5.7). In this case, little or no decrease in mercury contamination in fish is associated with the large reduction in mercury concentration and loading at EFK 23.4.

\subsubsection{Mercury Concentrations and Speciation in Forage Fish}

Total mercury and methylmercury in forage fish are presented in Figs. 5.8 and 5.9. The central stoneroller, an abundant herbivorous minnow, accumulated high concentrations of total mercury (Fig. 5.8), especially in the upper reaches of the stream, but relatively little of that mercury was methylmercury, the form that predominates in sunfish (Fig. 5.9). A clear downstream gradient in 


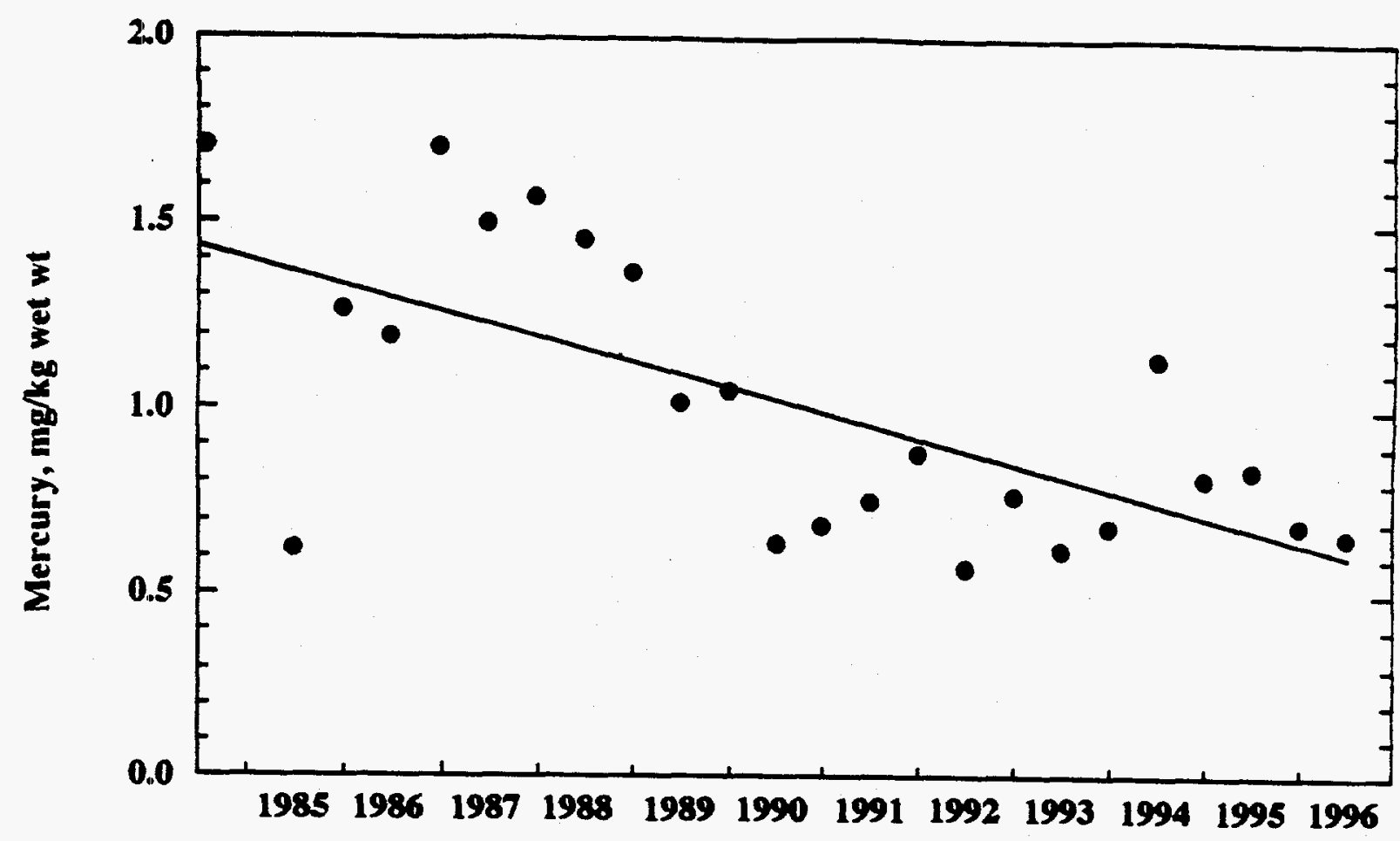

Fig. 5.4. Average mercury concentration in redbreast sunfish fillets, East Fork Poplar Creek at the Y-12 Plant boundary.

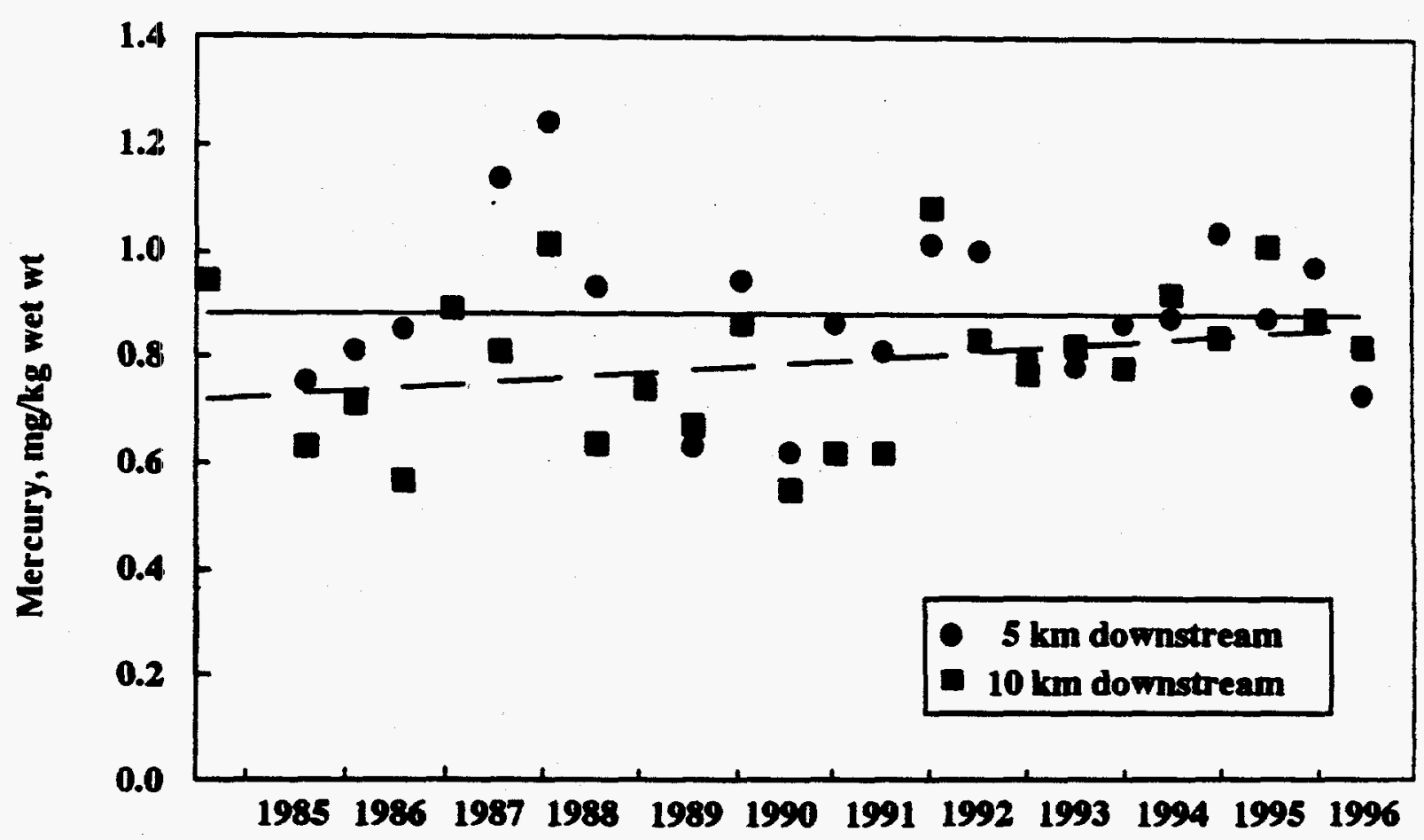

Fig. 5.5. Average mercury concentration in redbreast sunfish fillets, East Fork Poplar Creek, downstream from the Y-12 Plant boundary. 


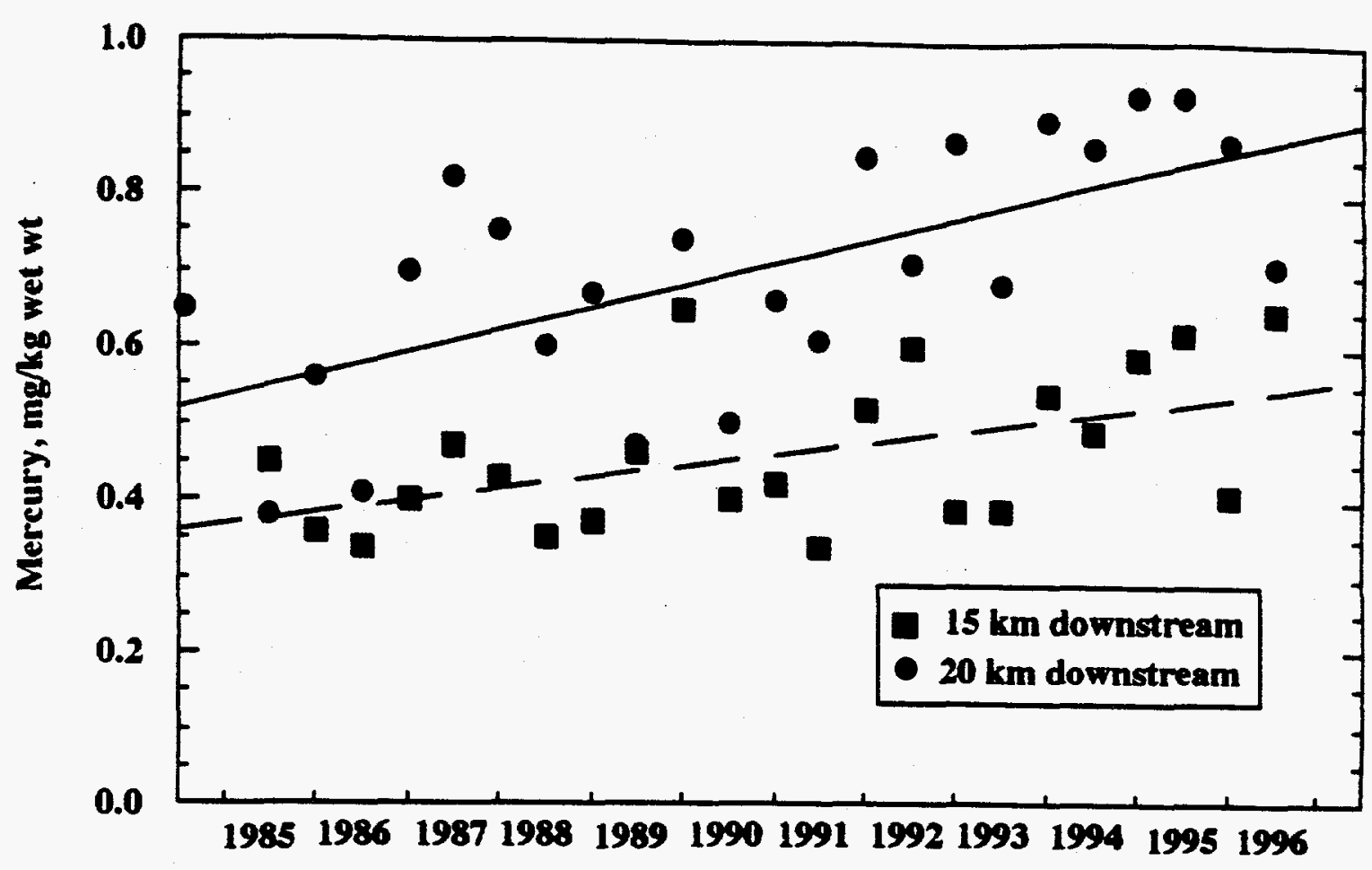

Fig. 5.6. Increase in mean mercury concentration in redbreast sunfish at sites in lower East Fork Poplar Creek. Both regression lines are statistically significant $(P<0.05)$.

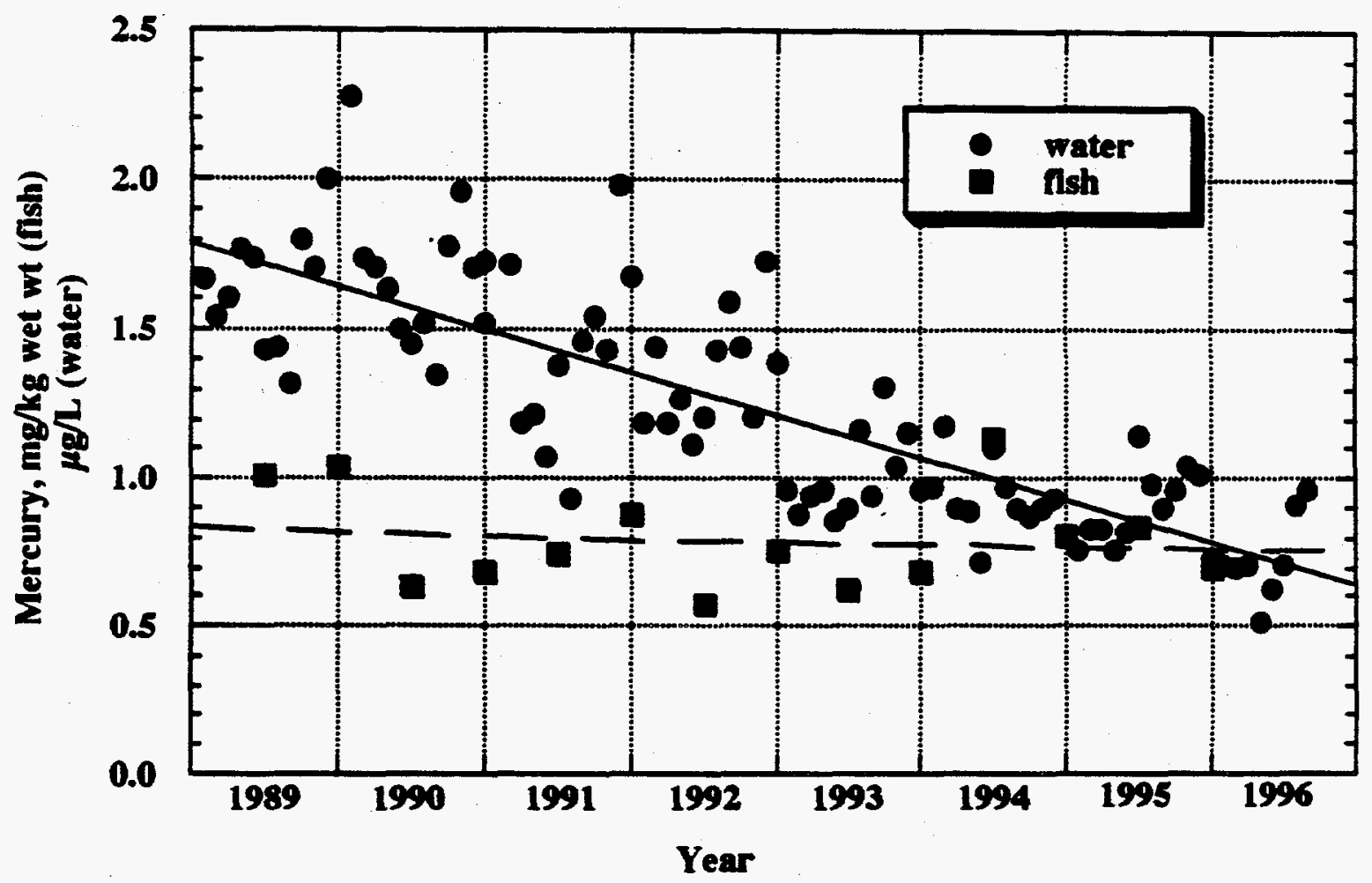

Fig. 5.7. Mercury in water and fish in East Fork Poplar Creek at the Y-12 Plant boundary since Lake Reality was completed. 


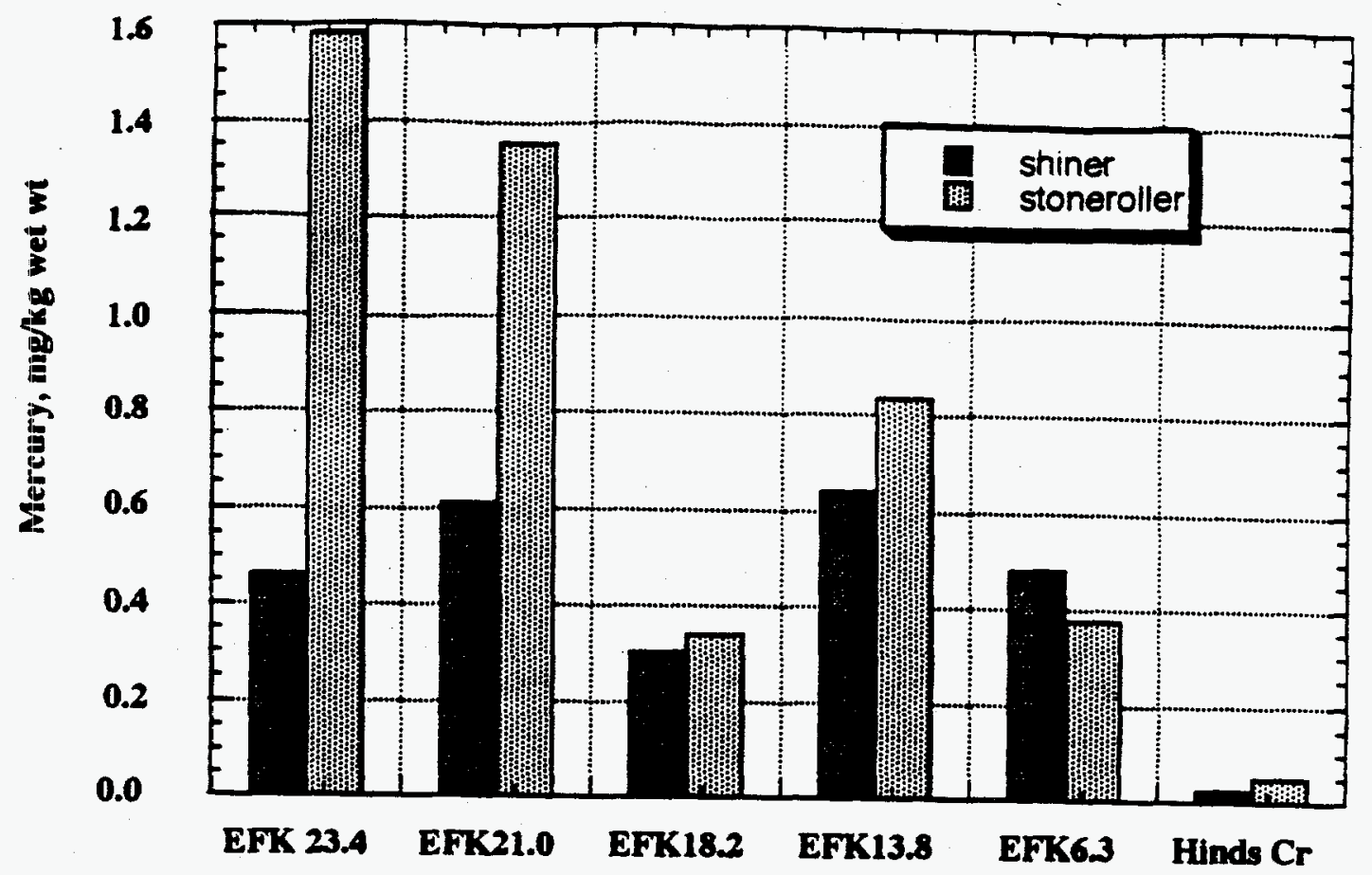

Fig. 5.8. Mean concentration of total mercury in composite samples $(n=3)$ of forage fish [stonerollers (Campostoma anomalum) and striped shiners (Luxilus chrysocephalus)] from sites in East Fork Poplar Creek.

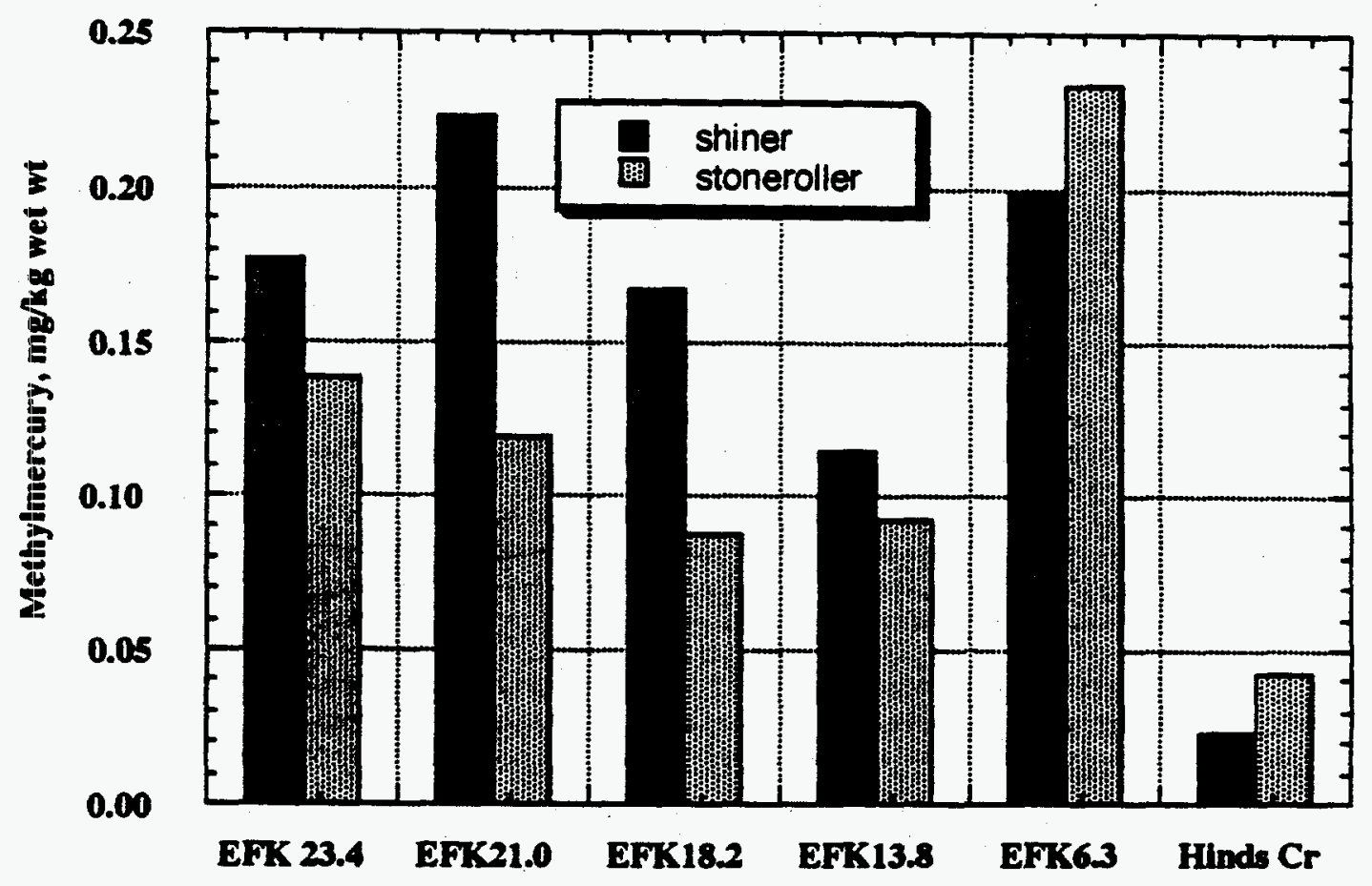

Fig. 5.9. Mean concentration of methylmercury in composite samples $(n=3)$ of forage fish [stonerollers (Campostoma anomalum) and striped shiners (Luxilus chrysocephalus)] from sites in East Fork Poplar Creek. 
mercury concentrations was evident, similar to that observed in sunfish in the late 1980s (Fig. 5.3). Total mercury concentrations in striped shiner, a more omnivorous forage fish, were generally lower than those found in stonerollers near the Y-12 Plant, but the two species were comparable downstream. A clear downstream gradient was not evident; instead the downstream mercury profile was similar to that observed for sunfish (Fig. 5.2).

Methylmercury concentrations in the two species were similar, and did not appear to increase or decrease with distance from Y-12 (Fig. 5.9). Methylmercury concentrations in whole body analyses of forage species are about $25 \%$ or less than concentrations found in sunfish fillets. Concentrations of the much less toxic inorganic mercury in forage species are high enough ( 40 to $90 \%$ of total $\mathrm{Hg}$ ) that evaluations of risk to piscivorous wildlife based on assumptions of $100 \%$ methylmercury in forage species are likely to be substantially overestimated. The unexpectedly low bioaccumulation of mercury by largemouth bass in Lake Reality and EFPC downstream may be related to their consumption of forage fish that are relatively low in methylmercury.

\subsubsection{Relationship Between Concentrations of Total Mercury in Water and Bioaccumulation of Mercury by Fish}

The NPDES permit at the Oak Ridge Y-12 Plant seeks to control mercury bioaccumulation by regulating the concentration of total mercury in EFPC. "Safe" or allowable total mercury concentration $(0.012 \mu \mathrm{g} / \mathrm{L})$ follows EPA guidance (water quality criteria). Bioaccumulation of mercury is known to be influenced by site-specific factors, hence a "safe" concentration of total mercury in the limestone fed streams of the Appalachian Ridge and Valley Province is likely to be different from that determined to be safe in soft, low-pH waters of the southern coastal plains or northern Midwest. Preliminary data relating mercury concentrations in sunfish fillets to total mercury concentrations in water at the site of collection are presented in Fig. 5.10.

In addition to BMAP sites in EFPC, data were included from two mercury-contaminated sites in Virginia (South River at Waynesboro and North Fork Holston River at Saltville), a site at the Paducah Gaseous Diffusion Plant in Kentucky, and White Oak Creek at ORNL. The two latter sites exhibit evidence of above background bioaccumulation of mercury despite maintaining mercury concentrations in receiving waters below routine analytical detection limits.

The relationship presented in Fig. 5.10 has been used previously with EFPC data to try to determine how far total mercury concentrations in water must be reduced to have mercury concentrations in fish fall below risk based thresholds (currently $0.4 \mathrm{mg} / \mathrm{kg}$ ). A deficiency of that analysis was that most data were obtained from sites where aqueous mercury concentrations were far above the targets thought to achieve reduction in bioaccumulation. By including sites where mercury contamination levels were lower but where water chemistry factors were similar, the analysis would depend less on extrapolation beyond the bounds of existing data.

As can be seen in Fig. 5.10, the relationship of mercury in fish versus mercury in water can be described as a first order approach to an asymptotic maximum concentration. In this analysis, a wide variation of data about the regression line is evident, with $0.4 \mathrm{mg} / \mathrm{kg}$ mercury in fish corresponding to less than $0.05 \mu \mathrm{g} / \mathrm{L}(50 \mathrm{ng} / \mathrm{L})$ total in water. Although this analysis suggests that greater mercury reductions than previously considered necessary may be needed to achieve the desired reductions in bioaccumulation, it does indicate that such reductions in bioaccumulation are likely to occur as the $0.2 \mu \mathrm{g} / \mathrm{L}(200 \mathrm{ng} / \mathrm{L})$ target associated with current mercury abatement efforts is approached. Furthermore, the data in Fig. 5.10 are from multiple (albeit similar) sites and may not be transferable to the EFPC situation. 


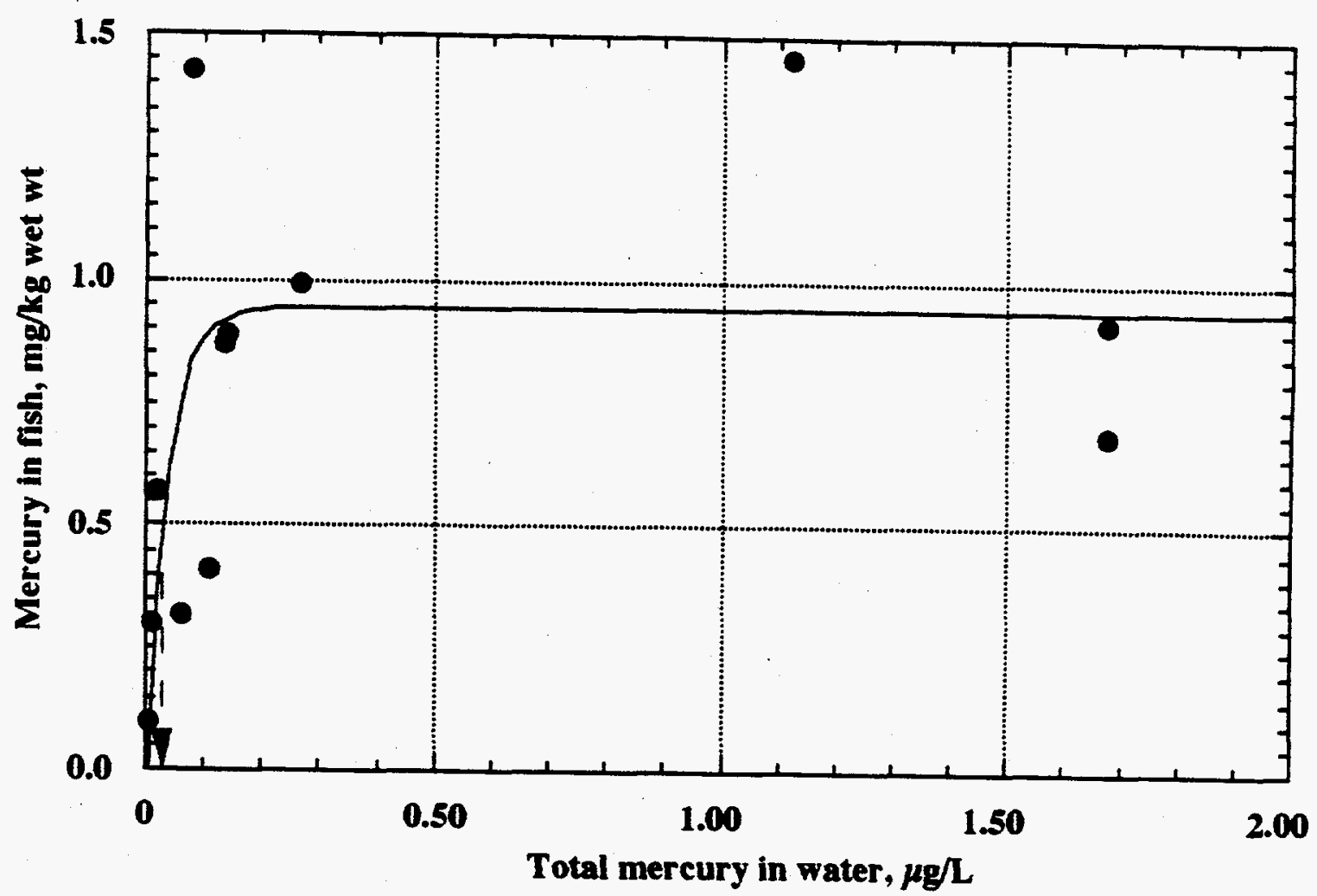

Fig. 5.10 Relationship between total mercury in sunfish fillets and total mercury in water in selected mercury-contaminated hardwater streams and reference streams.

\subsubsection{Effects of Mercury on EFPC Biota}

Since 1985, fish population density has increased at all sites in EFPC, but the greatest increases have occurred in the reaches within and immediately below the Y-12 Plant. Lake Reality and $2.5 \mathrm{~km}$ of EFF'C upstream from it now contain large populations of fish, whereas the same areas contained virtually no fish in the mid to late 1980s. Populations at EFK 23.4 and stream sites in the Y-12 Plant are 3 to 7 times greater than at comparable reference sites (Fig. 5.11). Fish in these expanded populations have accumulated methylmercury, which is efficiently recycled within the biotic components of the stream ecosystem, and inorganic mercury, which may be methylated in the decomposition process. Thus, although the concentration of mercury in fish and water has decreased at EFK 23.4 since 1985, the amount of mercury stored in fish populations at and above EFK 23.4 has increased many fold. This mercury must cycle (or spiral) its way downstream through EFPC for decreased mercury accumulation associated with source abatement to be fully manifest. That process may introduce a substantial time lag between actions and desired response in mercury remediation.

Two actions taken or to be taken in 1996 may significantly alter mercury transformation and bioaccumulation. Flow Management will decrease aqueous mercury concentrations and lower temperatures in EFPC above Lake Reality, reducing inorganic mercury bioaccumulation and possibly also methylmercury bioaccumulation. Bypassing Lake Reality will reduce aqueous mercury concentrations below Lake Reality substantially, and also isolate a large population of mercury-contaminated fish, reducing export of that source to EFPC. It is hoped that beneficial effects of these actions on mercury bioaccumulation will become evident in EFPC in 1997 or later. 
$5-11$

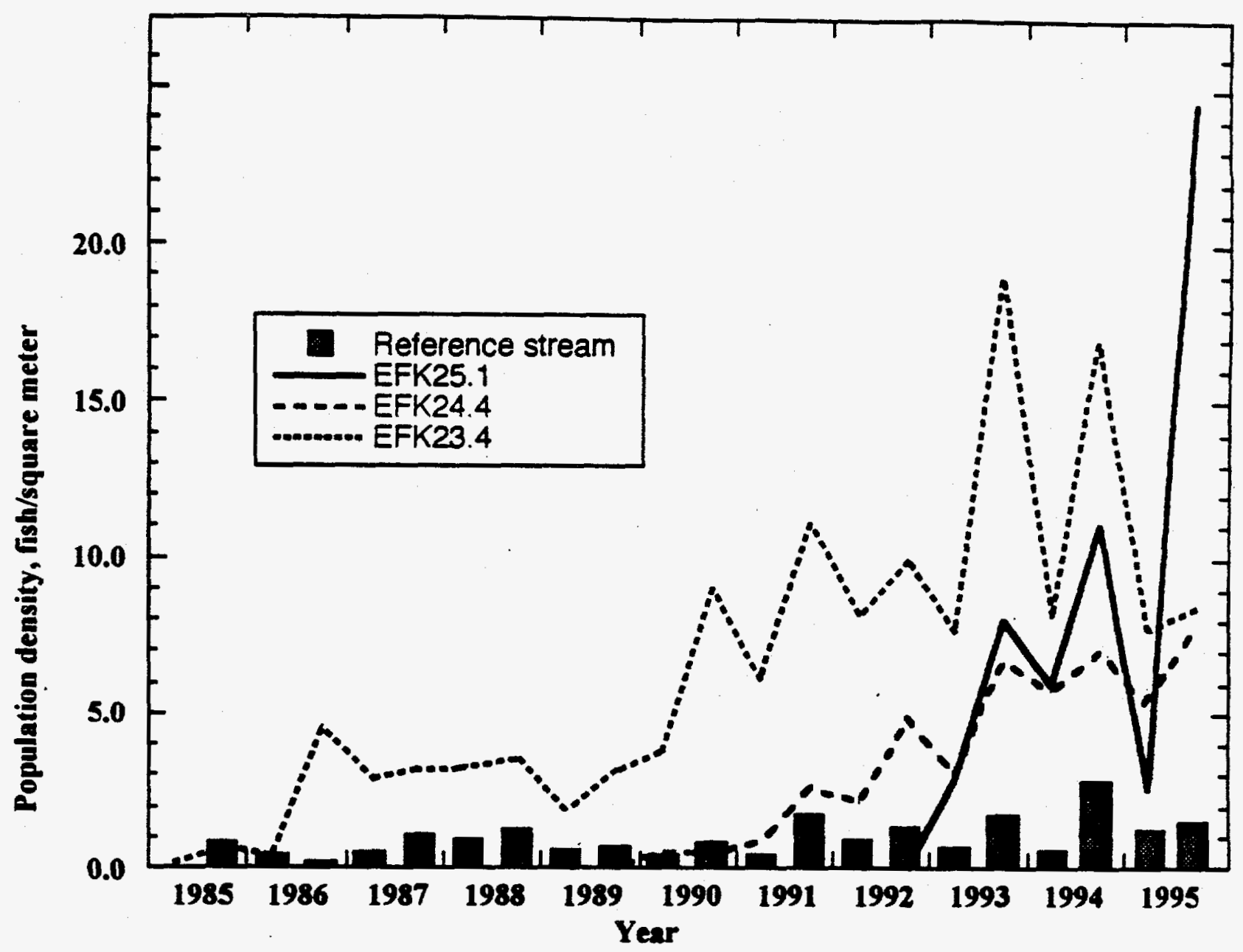

Fig. 5.11 Increase in fish population density in Upper East Fork Poplar Creek, 1985-1995. 


\section{MONITORING PLANS FOR FY 1997}

Characterization of mercury loading from outfalls and key instream locations will continue to be performed in FY 97 (1) to provide information on the effectiveness of specific corrective actions to reduce/eliminate mercury loading, (2) to define outfalls or Y-12 Plant areas where corrective actions are needed to help achieve the NPDES-imposed loading limit of $5 \mathrm{~g} /$ day, and (3) to provide mercury and mercury speciation data to support interpretation and application of Biological Monitoring and Abatement Program (BMAP) data in establishing a future site-specific criterion for mercury in water. Sampling activities will be divided in four categories: Monthly and semiannual grabs, daily and quarterly composites, semiannual longitudinal sampling of EFPC, and storm sampling. These activities are in addition to required and BMP sampling being performed under the auspices of the NPDES program.

Table 6.1 summarizes information for all key monitoring locations for mercury, including NPDES sites [9422-1 (Station 17), Outfall 51, Outfall 55], BMP sites (Outfall 200), and RMPE sites [Outfalls 47/48, 113, 150,160, 163, 169, north pipe emptying into catch basin E3250, Tank 2100U, 9422-3 (Station 8), 9422-15 and 9422-16]. Not included in Table 6.1 are several sites for which little or no recent data presently exist (e.g., catch basins upstream of Outfall 163). Sampling at these Y-12 Plant locations in FY 97 is expected to be of limited duration. Locations of BMAP sites downstream of Station 17 (9422-1) and not shown in Table 6.1 are given elsewhere in this report (Fig. 5.1). Sampling for mercury and mercury speciation at BMAP sites will occur in the November-December 1996 and May-June 1997 time periods.

Table 6.1 Key Y-12 Plant mercury monitoring locations for FY 1997

\begin{tabular}{|c|c|c|c|c|}
\hline Location & $\begin{array}{l}\text { Hg sample } \\
\text { type }\end{array}$ & $\begin{array}{l}\text { Hg sample } \\
\text { frequency }\end{array}$ & Program & Comments \\
\hline $\begin{array}{l}\text { Station } 17 \\
(9422-1)\end{array}$ & $\begin{array}{l}\text { Composite, } \\
\text { Grab }\end{array}$ & $\begin{array}{l}3 / \text { week } \\
5 / \text { week }\end{array}$ & NPDES & $\begin{array}{l}\text { Two } 48 \text {-h comp. plus one } 72 \text {-h } \\
\text { comp. } 5 / \text { wk grabs }\end{array}$ \\
\hline $\begin{array}{l}\text { RL Outlet } \\
\text { (EFPCK 23.4) }\end{array}$ & Grab & Semiannual & $\begin{array}{l}\text { RMPE, } \\
\text { BMAP }\end{array}$ & $\begin{array}{l}\text { Daily sampling will be } \\
\text { reevaluated after the initiation } \\
\text { of flow diversion }\end{array}$ \\
\hline $\begin{array}{c}\text { RL Inlet } \\
\text { (EFPCK 23.6) }\end{array}$ & Grab & $\begin{array}{c}5 / \text { week } \\
\text { Semiannual }\end{array}$ & $\begin{array}{l}\text { RMPE, } \\
\text { BMAP }\end{array}$ & $\begin{array}{l}\text { Daily sampling will be } \\
\text { reevaluated after the initiation of } \\
\text { flow diversion }\end{array}$ \\
\hline EFPCK 248 & Grab & Semiannual & BMAP & \\
\hline Outfall $47 / 48$ & Grab & Semiannual & RMPE & $\begin{array}{l}\text { In conjunction with Oct. and Apr. } \\
\text { monthly sampling }\end{array}$ \\
\hline Outfall 51 & Grab & Weekly & NPDES & \\
\hline Outfall 55 & Grab & Weekly & NPDES & \\
\hline $\begin{array}{l}\text { Station } 8 \\
(9422-3)\end{array}$ & Grab & $\begin{array}{l}\text { Monthly, } \\
\text { Semiannual }\end{array}$ & $\begin{array}{l}\text { RMPE, } \\
\text { BMAP }\end{array}$ & \\
\hline Outfall 113 & Grab & Semiannual & RMPE & $\begin{array}{l}\text { In conjunction with Oct. and Apr. } \\
\text { monthly sampling }\end{array}$ \\
\hline Outfall 135 & Grab & Quarterly & RMPE & $\begin{array}{l}\text { In conjunction with Oct, Jan, } \\
\text { Apr, and July monthly sampling }\end{array}$ \\
\hline
\end{tabular}


Table 6.1 (cont.)

\begin{tabular}{|c|c|c|c|c|}
\hline Location & $\begin{array}{c}\text { Hg sample } \\
\text { type }\end{array}$ & $\begin{array}{l}\text { Hg sample } \\
\text { frequency }\end{array}$ & Program & Comments \\
\hline $\begin{array}{l}\text { IVIS Pipe } \\
\text { (Oilfall 200) }\end{array}$ & Composite & I/week & $\begin{array}{l}\text { NPDES, } \\
\text { BMAP }\end{array}$ & Sampling at grate \\
\hline $\begin{array}{c}\text { N/S Pipe } \\
\text { (Outfall 200A) }\end{array}$ & $\begin{array}{l}\text { Grab, } \\
\text { Composite }\end{array}$ & $\begin{array}{l}\text { 5/week, } \\
\text { Quarterly }\end{array}$ & $\begin{array}{l}\text { RMPE, } \\
\text { RMPE }\end{array}$ & $\begin{array}{l}\text { Initiate monthly grabs when daily } \\
\text { grabs are discontinued }\end{array}$ \\
\hline Oitfall 150 & Grab & Quarterly & RMPE & $\begin{array}{l}\text { In conjunction with Oct, Jan, } \\
\text { Apr, and July monthly sampling }\end{array}$ \\
\hline 2100U Tank & Grab & Monthly & RMPE & Until CMTS operating \\
\hline Outfall 160 & Composite: & $\begin{array}{l}\text { Monthly, } \\
\text { Quarterily }\end{array}$ & RMPE & Five 24 h composites/gtr \\
\hline Outfall 163 & $\begin{array}{l}\text { Grab, } \\
\text { Composite }\end{array}$ & $\begin{array}{l}\text { Monthly, } \\
\text { Quarterly }\end{array}$ & RMPE & Five $24-\mathrm{h}$ composites/qtr \\
\hline E3250N & Grab, & $\begin{array}{l}\text { Monthly; } \\
\text { Quarterly }\end{array}$ & RMPE & $\begin{array}{l}\text { Until flow routed to CMTS, } \\
\text { Five } 24 \text { - } \text { composites/qtr }\end{array}$ \\
\hline Outfall 169 & $\begin{array}{l}\text { Grab, } \\
\text { Composite }\end{array}$ & $\begin{array}{l}\text { Monthly, } \\
\text { Quarterly }\end{array}$ & RMPE & Five $24-\mathrm{h}$ composites/qtr \\
\hline 9422,15 & Grab, & $\begin{array}{l}\text { Monthly, } \\
\text { Quarterly }\end{array}$ & RMPE & Five 24 h composites/gtr \\
\hline $9422-16$ & Grab & Quarterly & RMPE & $\begin{array}{l}\text { In conjunction with Oct., Jan., } \\
\text { Apr., and July sampling }\end{array}$ \\
\hline $\begin{array}{l}\text { Ouitfall } 550 \\
\text { (EEMTS) }\end{array}$ & Composite & $1 /$ week & $\begin{array}{l}\text { RMPE/ } \\
\text { NPDES }\end{array}$ & \\
\hline $\begin{array}{l}\text { Outfall } 551 \\
\text { (CMTS) }\end{array}$ & Composite & 1/week & $\begin{array}{l}\text { RMPE/ } \\
\text { NPDES }\end{array}$ & \\
\hline
\end{tabular}

\subsection{MONTHLY PROGRAM}

Sites for monthly grab sampling for mercury are indicated in the Table 6.1 column labeled " $\mathrm{Hg}$ Sample Frequency." These sites will be sampled on or near the 15 th of each month. These samples are meant to represent "dry weather" flow; thus no rainfall should have occurred $24 \mathrm{~h}$ before beginning sampling, and sampling will be terminated if rainfall begins during the sampling event.

Every effort will be made to obtain a reliable instantaneous water flow rate at the time of sampling. If the site has a functional and well-calibrated continuous flow device, instantaneous flow rate will be recorded from that device.

\subsection{QUARTERLY PROGRAM}

Sites for quarterly flow-proportional sampling are indicated in Table 6.1 under column heading "Hg Sample Type". Composite samples for $\mathrm{Hg}$ analysis will be collected with ISCO samplers interfaced with the respective flow devices at each location. A composite sampling event should 
consist of 5 successive 24-h samples, including at least 1 weekend day each quarter. Composite events will include stormwater from any rainfall that occurs during the 5-day period.

\subsection{STORMWATER PROGRAM}

Sites for stormwater sampling will continue to include 9422-1 (Station 17), Lake Reality Inlet, 9422-3 (Station 8) and N/S Pipe (Outfall 200). Additional sites may be added if warranted by results from these four sites and results from the screening study described below. A stormwater sampling event will be initiated when the forecast is favorable for rainfall from "frontal" activity. Such activity is more likely to generate significant and uniform rainfall over the Y-12 Plant site. Complete data for a minimum of four such storms is needed, but it is understood that more than four events may be initiated to obtain complete data for four events. Data from three storms were obtained in FY96, but two of these were incomplete in one way or another; thus additional effort is planned in FY 97. Complete details for the sampling strategy for stormwater are given in Work and $Q A$ Plan for R\&D in Support of the RMPE (Y/ER-221).

In summary, automated sequential samplers will be employed to collect a series of discrete samples over each storm hydrograph. Sample frequency during stormflow will be driven automatically by cumulative volume of flow and thus sample frequency will increase as flow rate increases. The analyte list will always include total $\mathrm{Hg}$ and TSS but will be expanded to include dissolved mercury and other analytes as appropriate to support the empirical assessment of stormflow mercury loading and numerical modeling of $\mathrm{Hg}$ transport.

\subsubsection{Stormwater Screening Study}

Quantitative assessment of stormflow loading of mercury in UEFPC is extremely challenging because of the size and complexity of the Y-12 Plant site and the requirement for accurate quantitative hydrology at each site selected for sampling. Few of the sites listed in Table 6.1 can provide accurate flow data over the range of flows expected to occur at these sites during heavy rainfall. Nor is it likely that the quality of flow data obtained during stormflow conditions can be improved cost effectively. For example, backwater effects or "embayment" on flow measuring sites when the main trunklines (e.g., N/S Pipe) are carrying substantial storm runoff can cause significant overestimates of instantaneous and thus total stormflow volumes. An alternative approach to identifying mercury sources during storm events is needed.

Mercury has a high association with, and inherent affinity for, particulate matter, as evidenced by the available stormwater data for the Y-12 Plant where partitioning between suspended particles and the dissolved phase has been measured. Accordingly, it is appropriate to focus on the mercury content ( $\mathrm{mg} / \mathrm{g}$, dry weight basis) of suspended matter carried by stormwater. Grab samples from areas (or hydrologic subbasins) where the values are high relative to other areas would represent candidate areas in which to search in detail for mercury sources (e.g., exposed contaminated soil subject to erosion and transport by storm runoff) and to plan remedies. The approach is very similar to that applied widely in mineral exploration wherein stream sediments are used to trace the location of ore bodies. Many samples can be collected and processed quickly with no requirement of quantitative hydrology. The absence of sediment deposits in most of the subterranean storm sewers at the Y-12 Plant precludes effective use of sediments.

Collection of grab samples of stormwater for the separation and analysis of mercury content of the suspended phase was begun on a trial basis in FY96 and will continue on a more intensive basis 
in FY97. The goal will be to develop a Plant-wide map showing the spatial distribution of mercury in the suspended phase. Data for such a map does not need to be collected synoptically, nor is this logistically possible. The map, or portions thereof, will be used to focus efforts to identify source areas of mercury, and to provide input to an improved hydrodynamic model of stormflow mercury transport.

\subsection{LONGITUDINAL PROGRAM}

Water samples will be collected semiannually at up to 12 locations along EFPC. Sampling will be contemporaneous with BMAP fish sampling and will use the same sites, plus additional sites, to better define gradients in mercury concentration and speciation. Some additional special surveys beyond the semiannual surveys may also be included to evaluate the effects of candidate corrective measures, such as permanent bypass of Lake Reality and tin-enhanced volatilization of mercury from UEFPC. Constituents to be measured include total mercury, dissolved mercury, total methylmercury, total dissolved methyl mercury, dissolved gaseous mercury, and total suspended matter. Because Lockheed Martin Energy Systems' analytical laboratories have no capability to run methylmercury, analytical services for most of these analyses will be obtained externally through the SMO, which will employ only certified labs. Procedures will conform to the requirements of the TSO. Dissolved gaseous mercury and total suspended matter will be measured in a research laboratory at the Oak Ridge National Laboratory.

As stated in the NPDES permit, information is required "...to reach a site alternate criterion for chronic exposure to mercury on the Oak Ridge Reservation (ORR)." Efforts to define an empirical relationship between aqueous total mercury concentration and mercury concentration in sunfish in hard water streams similar to EFPC will use data from regional reference and mercury contaminated streams in addition to EFPC. Because mercury or mercury speciation information is not available for the "background" fish sampling sites both on and off the ORR, some of these sites will be added for semiannual sampling for mercury speciation. 


\section{SUMMARY OF CURRENT CONDITIONS AND CONCLUSIONS}

Much progress has been made in the past few years towards the goal of reducing mercury releases to UEFPC to environmentally acceptable levels. The strategies followed to achieve this recent progress have been similar to those found effective in the mid-1980s. These strategies begin with characterization and prioritization of sources. Comprehensive surveys in 1993 of all dry weather flows into the creek identified key sources and permitted estimates of achievable reductions. These formed the basis of the proposed corrective actions itemized in the NPDES permit. As discussed in this report, the schedule for completion of corrective actions has been accelerated to provide an opportunity to identify and complete any additional actions necessary to meet the NPDES permit goal of $5 \mathrm{~g} /$ day by December 31, 1998. In addition, certain recognized sources (e.g., Outfall 51 and recently the catch basin at E3250N) initially thought to be beyond cost-effective treatment have been aggressively investigated and promising treatment options pursued. Thus, corrective actions for these difficult sources will be implemented in the near future. In other cases (e.g., Outfall 47/48), corrective actions upstream (pipe reroutes/replacements) not directed at mercury reduction have attenuated $\mathrm{Hg}$ releases.

Mercury concentrations in sunfish in EFPC at the Y-12 Plant boundary continue to be considerably lower than in the mid-1980s. However, the absence of a downward temporal trend in mercury contamination in fish at the plant boundary continues to be disappointing. No change is apparent at this site or in the middle reaches of EFPC over the past few years. In early FY97, aqueous mercury concentrations are expected to experience substantially larger reductions than have occurred since Outfall 49 was eliminated and the mercury treatment facility in Bldg. 9201-2 became operational. This is due to operation of the CMTS and the bypass of Lake Reality. It is hoped that these reductions will eventually be manifested in decreasing mercury levels in fish.

As previously discussed in Y/ER-251, there is a large reservoir of biologically incorporated methylmercury within, and upstream of, Lake Reality that must cycle through the system for decreases in mercury concentration in fish at the plant boundary and downstream to be evident. Time lags associated with cycling of residual methylmercury in fish might be reduced by active management of the fish population in EFPC above Lake Reality, with the separate goals of increasing species richness and reducing the inventory of biologically incorporated mercury. 


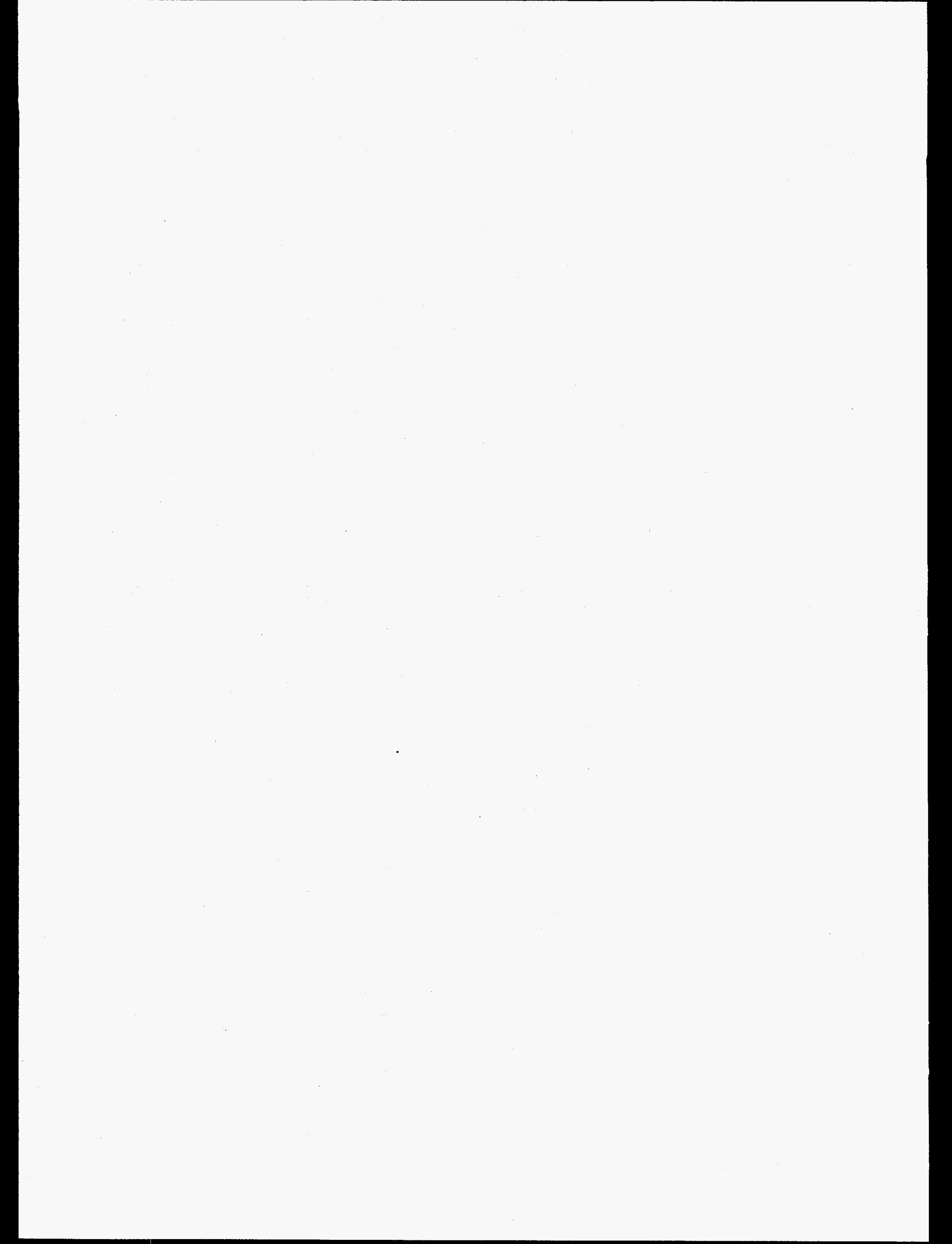




\section{APPENDIX A}

Results of Monthly Grab Sampling Program for Fiscal Year 1996 


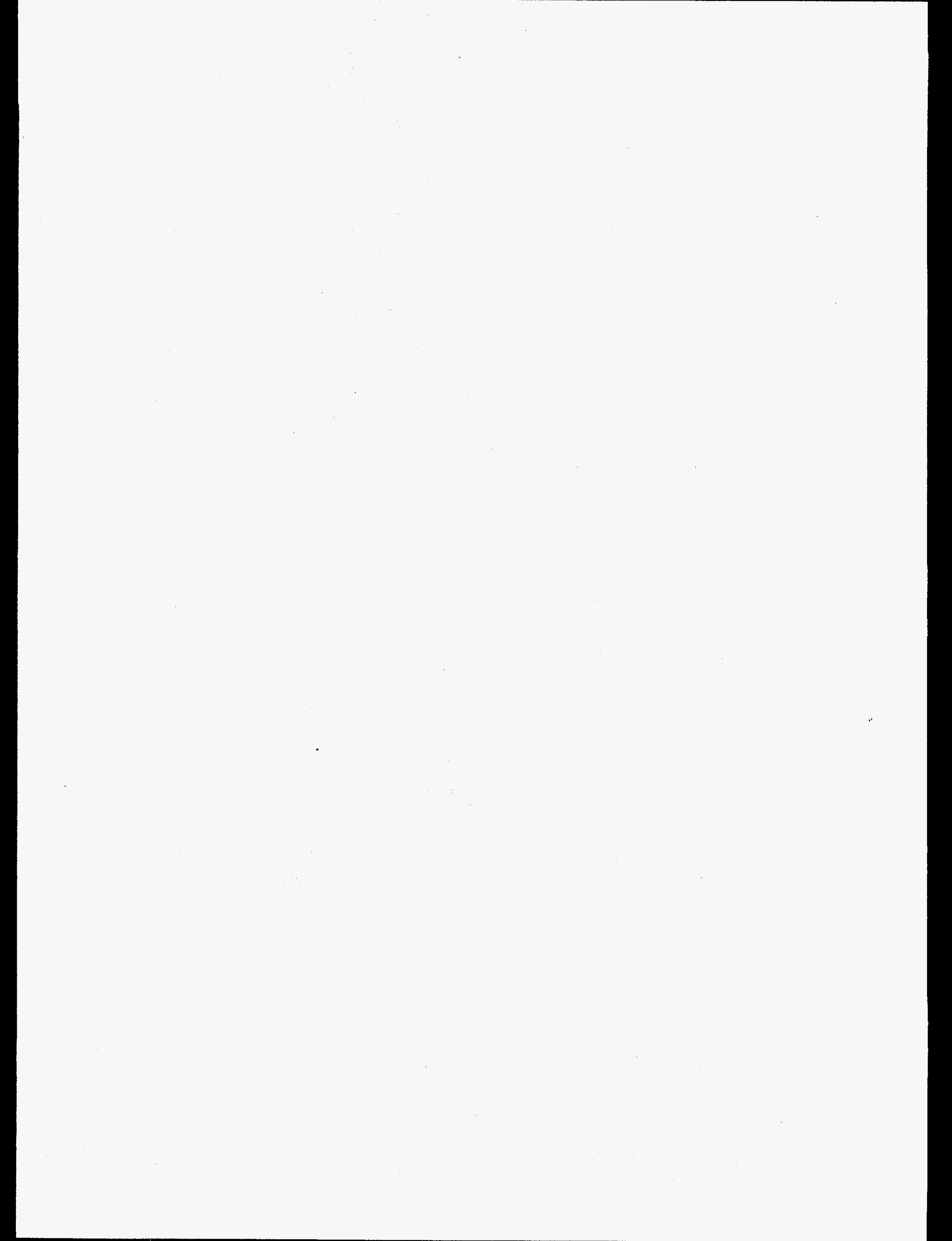


Table A.1 Results of monthly grab sampling program for fiscal year 1996

\begin{tabular}{|c|c|c|c|c|c|c|c|c|c|c|c|c|}
\hline \multirow[b]{2}{*}{ Sampling Date } & \multicolumn{3}{|c|}{$9422-16$} & \multicolumn{3}{|c|}{$9422-15$} & \multicolumn{3}{|c|}{ E3250N } & \multicolumn{3}{|c|}{ OF 169} \\
\hline & Flow (gpm) & $\begin{array}{c}\text { Hg Conc. } \\
(\mu \mathrm{g} / \mathrm{L})\end{array}$ & $\begin{array}{c}\text { Hg } \\
\text { Loading } \\
\text { (g/day) }\end{array}$ & $\begin{array}{c}\text { Flow } \\
\text { (gpm) }\end{array}$ & $\begin{array}{c}\text { Hg } \\
\text { Conc. } \\
(\mu g / L)\end{array}$ & $\begin{array}{c}\text { Hg } \\
\text { Loading } \\
\text { (g/day) }\end{array}$ & $\begin{array}{c}\text { Flow } \\
\text { (gpm) }\end{array}$ & $\begin{array}{c}\text { Hg } \\
\text { Conc. } \\
(\mu g / L)\end{array}$ & $\begin{array}{c}\text { Hg } \\
\text { Loading } \\
\text { (g/day) }\end{array}$ & $\begin{array}{c}\text { Flow } \\
\text { (gpm) }\end{array}$ & $\begin{array}{c}\text { Hg Conc. } \\
(\mu \mathrm{g} / \mathrm{L})\end{array}$ & $\begin{array}{c}\text { Hg } \\
\text { Loading } \\
\text { (g/day) }\end{array}$ \\
\hline $100 \operatorname{ct95}$ & 34 & 0.6 & 0.11 & 110 & 1.1 & 0.66 & & & & 140 & 5.7 & 4.35 \\
\hline 14 Nov95 & 80 & $<0.2$ & $<0.09$ & 160 & 0.7 & 0.61 & & & & 190 & 3.7 & 3.83 \\
\hline 12Dec95 & 46 & 0.3 & 0.08 & 142 & 0.9 & 0.70 & & & & 130 & 4 & 2.83 \\
\hline $16 J \tan 96$ & 78 & $<0.2$ & $<0.09$ & 170 & 0.8 & 0.74 & & & & $270^{*}$ & $6.8^{*}$ & $10^{*}$ \\
\hline 13 Feb96 & 78 & $<0.2$ & $<0.09$ & 114 & 0.5 & 0.31 & & & & 199 & 2.4 & 2.60 \\
\hline 12Mar96 & 63 & $<0.2$ & $<0.07$ & 110 & 0.4 & 0.24 & & & & 240 & 2.2 & 2.88 \\
\hline 10Apr96 & 61 & $<0.2$ & $<0.07$ & 103 & 0.45 & 0.25 & & & & 150 & 3.6 & 2.94 \\
\hline 14May96 & 49 & 0.3 & 0.08 & 86 & 1.3 & 0.61 & & & & 190 & 2.2 & 2.28 \\
\hline 18Jun96 & 47 & 0.4 & 0.10 & 89 & 0.3 & 0.15 & & & & 129 & 2 & 1.41 \\
\hline $17 J u 196$ & 39 & 0.4 & 0.09 & 73 & 0.4 & 0.16 & & & & 159 & 2.2 & 1.91 \\
\hline 15Aug96 & 38 & $<0.2$ & $<0.04$ & 94 & 0.6 & 0.31 & 8 & 79 & 3.44 & 150 & 2.3 & 1.88 \\
\hline Average & 56 & $<0.29$ & $<0.08$ & 114 & 0.68 & 0.43 & 8 & 79 & 3.4 & 168 & 3.0 & 2.7 \\
\hline $\mathbf{N}$ & 11 & 11 & 11 & 11 & 11 & 11 & 1 & 1 & 1 & 10 & 10 & 10 \\
\hline Maximum & 80 & 0.6 & 0.11 & 170 & 1.3 & 0.74 & 8 & 79 & 3.4 & 240 & 5.7 & 4.35 \\
\hline Minimum & 34 & $<0.2$ & $<0.04$ & 73 & 0.3 & 0.15 & 8 & 79 & 3.4 & 129 & 2.0 & 1.41 \\
\hline
\end{tabular}


Tabie A.î (cont.)

\begin{tabular}{|c|c|c|c|c|c|c|c|c|c|c|c|c|}
\hline \multirow[b]{2}{*}{ Sampling Date } & \multicolumn{3}{|c|}{ OF 163} & \multicolumn{3}{|c|}{ OF 160} & \multicolumn{3}{|c|}{$2100 U$} & \multicolumn{3}{|c|}{ OF 150} \\
\hline & $\begin{array}{c}\text { Flow } \\
\text { (gpm) }\end{array}$ & $\begin{array}{c}\text { Hg Conc. } \\
(\mu \mathrm{g} / \mathrm{L})\end{array}$ & $\begin{array}{c}\text { Hg } \\
\text { Loading } \\
\text { (g/day) }\end{array}$ & $\begin{array}{c}\text { Flow } \\
\text { (gpm) }\end{array}$ & $\begin{array}{c}\text { Hg Conc. } \\
(\mu \mathrm{g} / \mathrm{L})\end{array}$ & $\begin{array}{c}\text { Hg } \\
\text { Loading } \\
\text { (g/day) }\end{array}$ & $\begin{array}{c}\text { Flow } \\
(\mathrm{gpm})\end{array}$ & $\begin{array}{c}\text { Hg Conc. } \\
(\mu \mathrm{g} / \mathrm{L})\end{array}$ & $\begin{array}{c}\text { Hg } \\
\text { Loading } \\
\text { (g/day) }\end{array}$ & $\begin{array}{c}\text { Flow } \\
\text { (gpm) }\end{array}$ & $\begin{array}{c}\text { Hg Conc. } \\
(\mu \mathrm{g} / \mathrm{L})\end{array}$ & $\begin{array}{c}\text { Hg } \\
\text { Loading } \\
\text { (g/day) }\end{array}$ \\
\hline $100 \mathrm{ct9s}$ & 240 & 1.3 & 1.70 & $6^{*}$ & 7.2 & $0.24 *$ & & & & 390 & $<0.2$ & $<0.43$ \\
\hline 14Nov95 & 320 & 2.8 & 4.88 & $11 *$ & 6.3 & $0.38^{*}$ & & & & 408 & $<0.2$ & $<0.44$ \\
\hline 12Dec95 & 227 & 1.8 & 2.23 & 45 & 4.9 & 1.20 & 9 & 42 & 2.06 & 426 & $<0.2$ & $<0.46$ \\
\hline $16 \mathrm{Jan} 96$ & 256 & 2.4 & 3.35 & 31 & 3.4 & 0.57 & $26^{*}$ & 28 & $3.97 *$ & & & \\
\hline 13 Feb96 & 245 & 1.1 & 1.47 & 46 & 3 & 0.75 & 16 & 24 & 2.09 & & & \\
\hline 12Mar96 & 365 & 1 & 1.99 & 25 & 1.8 & 0.25 & 4 & 26 & 0.57 & & & \\
\hline 10 Apr96 & 310 & 1.2 & 2.03 & 20 & 7.9 & 0.86 & 7 & 30 & 1.14 & & & \\
\hline 14 May96 & 305 & 1 & 1.66 & 12 & 15 & 0.98 & 15 & 36.5 & 2.98 & & & \\
\hline 18Jun96 & 296 & 0.9 & 1.45 & 18 & 7.6 & 0.75 & 7 & 47 & 1.79 & & & \\
\hline 17Jul96 & 182 & 1.9 & 1.88 & 17 & 9.5 & 0.88 & 3 & 36 & 0.59 & & & \\
\hline 15Aug96 & 175 & 1.2 & 1.14 & 26 & 6.6 & 0.94 & 5 & 33 & 0.90 & & & \\
\hline Average & 266 & 1.5 & 2.2 & 27 & 6.7 & 0.80 & 8.3 & 34 & 1.5 & 408 & $<0.2$ & $<0.44$ \\
\hline $\mathbf{N}$ & 11 & 11 & 11 & 9 & 11 & 9 & 8 & 9 & 8 & 3 & 3 & 3 \\
\hline Maximum & 365 & 2.8 & 4.88 & 46 & 15 & 1.2 & 16 & 47 & 2.98 & 426 & $<0.2$ & $<0.46$ \\
\hline Minimum & 175 & 0.9 & 1.14 & 12 & 1.8 & 0.25 & 3 & 24 & 0.57 & 390 & $<0.2$ & $<0.43$ \\
\hline
\end{tabular}

*Suspect dry weather flows and $\mathrm{Hg}$ loading calculations. These dates were not used in monthly dry weather statistical summaries. 
Table A.1 (cont.)

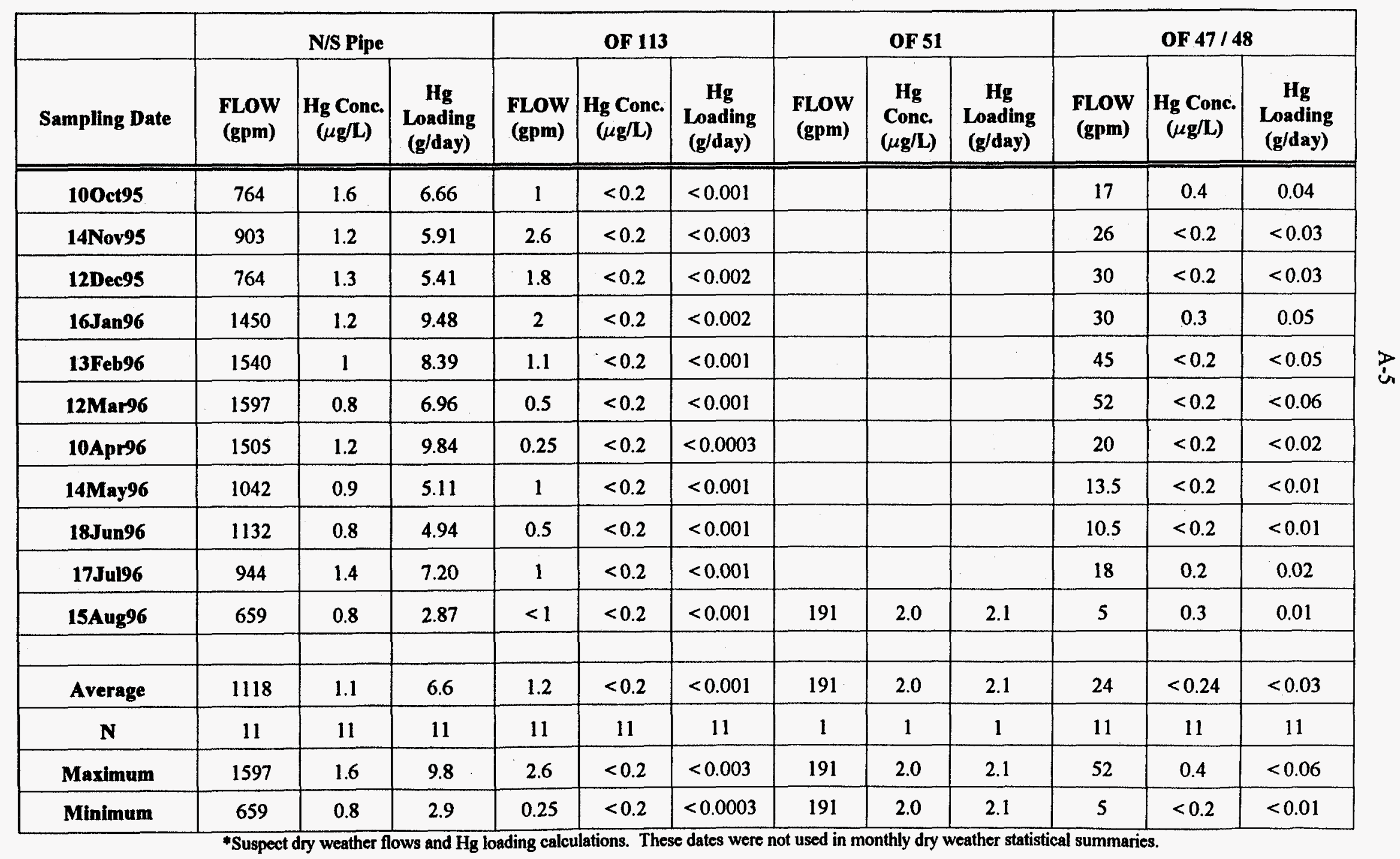


A-6

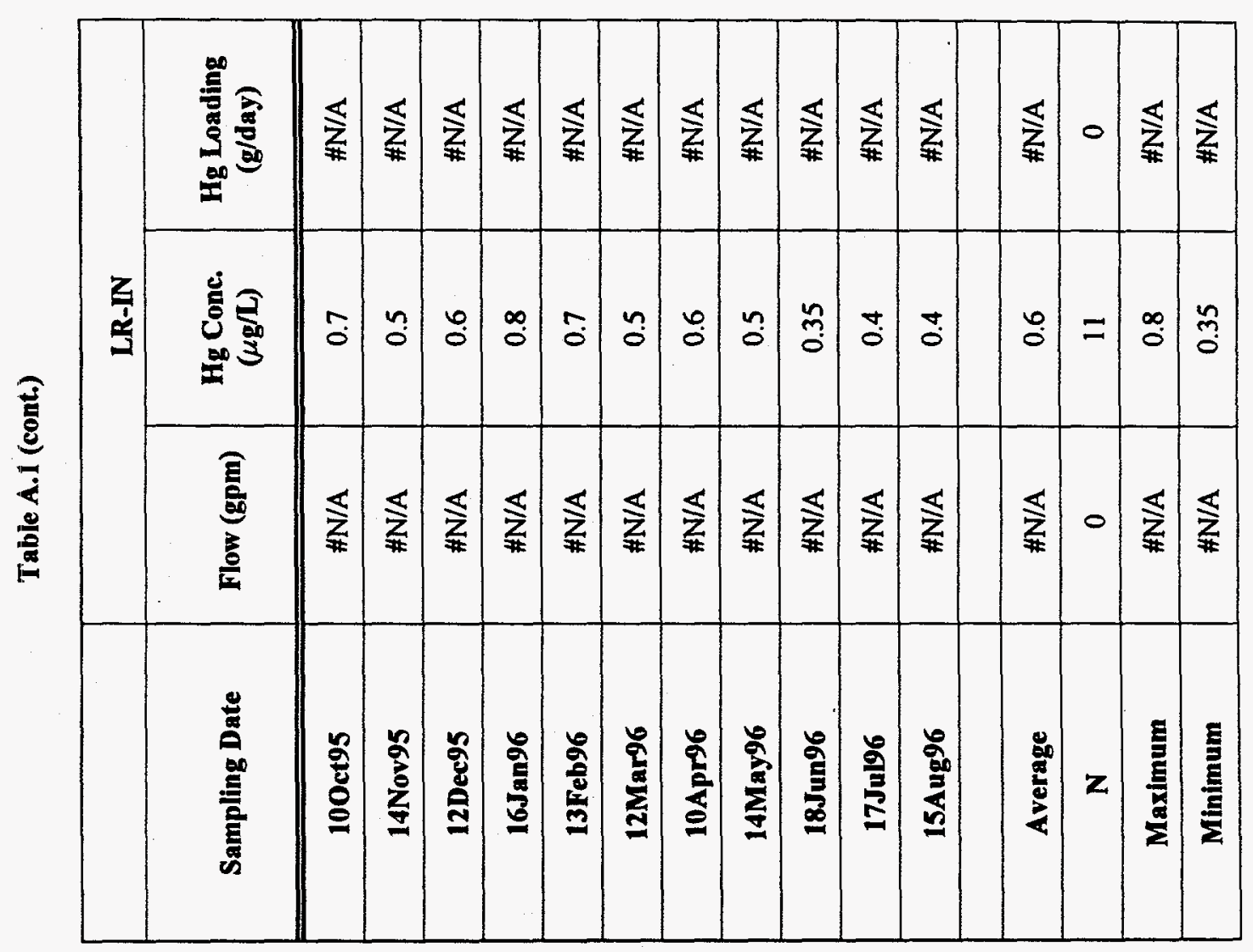




\section{APPENDIX B}

Results of Quarterly Composite Sampling Program for Fiscal Year 1996 

B-3

Table B.1. Results of the quarterly composite sampling for fiscal year 1996. Negative signs before values indicate 'less than'.

\begin{tabular}{|c|c|c|c|c|c|c|c|c|}
\hline $\begin{array}{l}\text { Sampling } \\
\text { Lacation }\end{array}$ & Quarter & $\begin{array}{c}\text { Date } \\
\text { Removed }\end{array}$ & Day & Day of Week & Total Flow & $\mathbf{H g}$ & Hg Loading & COMMENTS \\
\hline & & & & $8: 00-8: 00$ & (ga/day) & $(\mu g / L)$ & (g/day) & \\
\hline OF 47 & 1 & 26-Feb-96 & 1 & Sun-Mon & 20020 & -0.2 & -0.02 & \\
\hline OF 47 & 1 & $27-F e b-96$ & 2 & Mon-Tues & 16076 & 0.3 & 0.02 & \\
\hline OF 47 & 1 & 28-Feb-96 & 3 & Tues-Wed & 35795 & 0.2 & 0.03 & Rainfall \\
\hline OF 47 & 1 & 29-Feb-96 & 4 & Wed-Thur & 35004 & -0.2 & -0.03 & \\
\hline OF 47 & 1 & 01-Mar-96 & 5 & Thur-Fri & 34720 & -0.2 & -0.03 & \\
\hline OF 47 & 2 & 29-Apr-96 & 1 & Sun-Mon & 19197 & -0.2 & -0.01 & \\
\hline of 47 & 2 & 30-Apr-96 & 2 & Mon-Tues & 59792 & -0.2 & -0.05 & Rainfall \\
\hline OF 47 & 2 & 01-May-96 & 3 & Tues-Wed & 93647 & -0.2 & -0.07 & . \\
\hline OF 47 & 2 & 02-May-96 & 4 & Wed-Thur & 24121 & -0.2 & -0.02 & \\
\hline OF 47 & 2 & 03-May-96 & 5 & Thur-Fri & 20869 & -0.2 & -0.02 & \\
\hline OF 47 & 2 & 03-May-96 & 5 dup. & Thur-Fri & 20869 & -0.2 & -0.02 & \\
\hline N/S PIPE & 1 & 26-Feb-96 & 1 & Sun-Mon & 1975000 & 0.6 & 4.5 & \\
\hline N/S PIPE & 1 & 27-Feb-96 & 2 & Mon-Tues & 2128000 & 0.6 & 4.8 & \\
\hline N/S PIPE & 1 & 28-Feb-96 & 3 & Tues-Wed & 3562800 & 2.7 & 36.4 & Rainfall \\
\hline N/S PIPE & 1 & 29-Feb-96 & 4 & Wed-Thur & 2479100 & 0.8 & 7.5 & \\
\hline N/S PIPE & 1 & 01-Mar-96 & 5 & Thur-Fri & 2378800 & 0.7 & 6.3 & \\
\hline N/S PIPE & 1 & 02-Mar-96 & 6 & Fri-Sat & 2155000 & 0.6 & 4.9 & \\
\hline N/S PIPE & 2 & 29-Apr-96 & 1 & Sun-Mon & 1899100 & 0.7 & 5.0 & Flows are over-estimated \\
\hline N/S PIPE & 2 & 29-Apr-96 & 1 dup. & Sun-Mon & 1899100 & 0.7 & 5.0 & because of construction \\
\hline N/S PIPE & 2 & 30-Apr-96 & 2 & Mon-Tues & 5684000 & 0.8 & 17.2 & Rainfall \\
\hline N/S PIPE & 2 & 01-May-96 & 3 & Tues-Wed & 3082800 & 1.0 & 11.7 & \\
\hline N/S PIPE & 2 & 02-May-96 & 4 & Wed-Thur & 2513000 & 0.9 & 8.6 & \\
\hline N/S PIPE & 2 & 03-May-96 & 5 & Thur-Fri & 2393600 & 0.8 & 7.2 & \\
\hline
\end{tabular}


Table B.1. (cont.)

\begin{tabular}{|c|c|c|c|c|c|c|c|c|}
\hline $\begin{array}{l}\text { Sampling } \\
\text { Location }\end{array}$ & Quarter & $\begin{array}{c}\text { Date } \\
\text { Removed }\end{array}$ & Day & Day of Week & Total Flow & Hg & Hg Loading & COMMENTS \\
\hline & & & & $8: 00-8: 00$ & (gaV/day) & $(\mu \mathrm{g} / \mathrm{L})$ & (g/day) & \\
\hline N/S PIPE & 3 & 15-Jul-96 & 1 & Sun-Mon & 3898000 & 1.7 & 25.1 & Rain 1.5 inches - $8 \mathrm{hr}$. sample \\
\hline N/S PIPE & 3 & 16-Jul-96 & 2 & Mon-Tues & 3404800 & 1.8 & 23.2 & Rain 0.51 inches \\
\hline N/S PIPE & 3 & 17-Jul-96 & 3 & Tues-Wed & 1426900 & 1.2 & 6.5 & \\
\hline N/S PIPE & 3 & 18-Jul-96 & 4 & Wed-Thur & 1357400 & 1.0 & 5.1 & \\
\hline N/S PIPE & 3 & 19-Jul-96 & 5 & Thur-Fri & 2865400 & 1.0 & 10.8 & \\
\hline $2100 \mathrm{U}$ & 1 & 26-Feb-96 & 1 & Sun-Mon & $\mathrm{N} / \mathrm{A}$ & - & $\therefore$ & Eq. Failure \\
\hline 21000 & 1 & 27-Feb-96 & 2 & Mon-Tues & 9800 & 11 & 0.41 & \\
\hline $2190 \mathrm{U}$ & 1 & 28-Feb-96 & 3 & Tues-Wed & 11630 & 13 & 0.57 & Rainfall \\
\hline 21000 & 1 & 29-Feb-96 & 4 & Wed-Thur & 15000 & 16 & 0.91 & \\
\hline $2100 \mathrm{U}$ & 1 & 29-Feb-96 & 4 dup. & Wed-Thur & 15000 & 15 & 0.85 & \\
\hline $2100 \mathrm{U}$ & 1 & 01-Mar-96 & 5 & Thur-Fri & 14390 & 12 & 0.65 & \\
\hline $2100 \mathrm{U}$ & 1 & 02-Mar-96 & 6 & Fri-Sat & 14250 & 11 & 0.59 & \\
\hline $2100 \mathrm{U}$ & 2 & 29-Apr-96 & 1 & Sun-Mon & 12390 & 17 & 0.80 & \\
\hline $2100 \mathrm{U}$ & 2 & 30-Apr-96 & 2 & Mon-Tues & $26570 ?$ & 19 & $1.9 ?$ & Rainfall \\
\hline $2100 \mathrm{U}$ & 2 & 01-May-96 & 3 & Tues-Wed & 14010 & 18 & 1.0 & \\
\hline $2100 \mathrm{U}$ & 2 & 02-May-96 & 4 & Wed-Thur & - & - & - & Flow meter problems \\
\hline $2100 \mathrm{U}$ & 2 & 03-May-96 & 5 & Thur-Fri & 12130 & 16 & 0.73 & \\
\hline $2100 \mathrm{U}$ & 3 & 15-Jul-96 & 1 & Sun-Mon & 19500 & 34 & 2.51 & Rain 1.5 inches \\
\hline $2100 \mathrm{U}$ & 3 & 16-Jul-96 & 2 & Mon-Tues & 31640 & 31 & 3.71 & Rain 0.51 inches \\
\hline $2100 \mathrm{U}$ & 3 & 17-Jul-96 & 3 & Tues-Wed & 15740 & 19 & 1.13 & \\
\hline $2100 \mathrm{U}$ & 3 & 18-Jul-96 & 4 & Wed-Thur & 12490 & 17 & 0.80 & \\
\hline $2100 \mathrm{U}$ & 3 & 19-Jul-96 & 5 & Thur-Fri & 11130 & 16 & 0.67 & \\
\hline
\end{tabular}


Table B.1. (cont.)

\begin{tabular}{|c|c|c|c|c|c|c|c|c|}
\hline $\begin{array}{l}\text { Sampling } \\
\text { Location }\end{array}$ & Quarter & $\begin{array}{c}\text { Date } \\
\text { Removed } \\
\end{array}$ & Day & Day of Week & Total Flow & Hg & Hg Loading & COMMENTS \\
\hline & & & & $8: 00-8: 00$ & (gal/day) & $(\mu \mathrm{g} / \mathrm{L})$ & (g/day) & \\
\hline OF 160 & 1 & 26-Feb-96 & 1 & Sun-Mon & 7000 & 4.3 & 0.11 & Flume Leaking \\
\hline OF 160 & 1 & 27-Feb-96 & 2 & Mon-Tues & 6400 & 4.3 & 0.10 & Flume Leaking \\
\hline OF 160 & 1 & 28-Feb-96 & 3 & Tues-Wed & 27700 & 6.4 & 0.67 & Rainfall \\
\hline OF 160 & 1 & 29-Feb-96 & 4 & Wed-Thur & 36600 & 4.3 & 0.60 & \\
\hline OF 160 & 1 & 01-Mar-96 & 5 & Thur-Fri & 50300 & 2.3 & 0.44 & \\
\hline OF 160 & 1 & 02-Mar-96 & 6 & Fri-Sat & 48900 & 1.9 & 0.35 & \\
\hline OF 160 & 2 & 29-Apr-96 & 1 & Sun-Mon & 28500 & 8.4 & 0.9 & \\
\hline OF 160 & 2 & 30-Apr-96 & 2 & Mon-Tues & 54400 & 6.5 & 1.3 & Plating shop discharge \\
\hline OF 160 & 2 & 01-May-96 & 3 & Tues-Wed & 43600 & 9.1 & 1.5 & \\
\hline OF 160 & 2 & 02-May-96 & 4 & Wed-Thur & 30600 & 9.5 & 1.1 & \\
\hline OF 160 & 2 & 03-May-96 & 5 & Thur-Fri & 27000 & 8.0 & 0.8 & \\
\hline OF 160 & 3 & 15-Jul-96 & 1 & Sun-Mon & 106500 & & & Equipment problems - no \\
\hline OF 160 & 3 & 16-Jul-96 & 2 & Mon-Tues & $219800 ?$ & & & Strainer washout - no sample \\
\hline OF 160 & 3 & 17-Jul-96 & 3 & Tues-Wed & 41300 & 7.5 & 1.2 & \\
\hline OF 160 & 3 & 18-Jul-96 & 4 & Wed-Thur & 34500 & 7.7 & 1.0 & \\
\hline OF 160 & 3 & 19-Jul-96 & 5 & Thur-Fri & 39200 & 7.6 & 1.1 & \\
\hline OF 160 & 3 & 20-Jul-96 & 6 & Fri-Sat & & 7.1 & $\# N / A$ & Power off? \\
\hline OF 163 & 1 & 26-Feb-96 & 1 & Sun-Mon & 516200 & 0.5 & 1.0 & \\
\hline OF 163 & 1 & 27-Feb-96 & 2 & Mon-Tues & 499400 & 0.5 & 0.9 & \\
\hline OF 163 & 1 & 28-Feb-96 & 3 & Tues-Wed & 605000 & 1.2 & 2.7 & Rainfall \\
\hline OF 163 & 1 & 29-Feb-96 & 4 & Wed-Thur & 506500 & 0.9 & 1.7 & \\
\hline OF 163 & 1 & 01-Mar-96 & 5 & Thur-Fri & 504700 & 1.0 & 1.9 & \\
\hline
\end{tabular}


Table B.1. (cont.)

\begin{tabular}{|c|c|c|c|c|c|c|c|c|}
\hline $\begin{array}{l}\text { Sampling } \\
\text { Location }\end{array}$ & Quarter & $\begin{array}{c}\text { Date } \\
\text { Removed }\end{array}$ & Day & Day of Week & Total Flow & Hg & Hg Loading & COMMENTS \\
\hline & & & & 8:00 - 8:00 & (ga/day) & $(\mu \mathrm{g} / \mathrm{L})$ & (g/day) & \\
\hline OF 163 & 2 & 29-Apr-96 & 1 & Sun-Mon & 476100 & 0.6 & 1.1 & \\
\hline OF 163 & 2 & 30-Apr-96 & 2 & Mon-Tues & 649200 & 0.9 & 2.2 & Rainfall \\
\hline OF 163 & 2 & 01-May-96 & 3 & Tues-Wed & 488100 & 0.8 & 1.5 & \\
\hline OF 163 & 2 & 02-May-96 & 4 & Wed-Thur & 471400 & 0.6 & 1.1 & \\
\hline OF 163 & 2 & 03-May-96 & 5 & Thur-Fri & 466700 & 0.6 & 1.1 & \\
\hline OF 163 & 2 & 03-May-96 & 5 dup. & Thur-Fri & 466700 & 0.6 & 1.1 & \\
\hline OF 163 & 3 & 15-Jul-96 & 1 & Sun-Mon & 699200 & 3.2 & 8.5 & Rain 1.5 inches \\
\hline OF 163 & 3 & 16-Jul-96 & 2 & Mon-Tues & 509700 & 1.4 & 2.7 & Rain 0.51 inches \\
\hline OF 163 & 3 & 17-Jul-96 & 3 & Tues-Wed & 269300 & 2.1 & 2.1 & \\
\hline OF 163 & 3 & 18-Jul-96 & 4 & Wed-Thur & 253800 & 1.6 & 1.5 & \\
\hline OF 163 & 3 & 19-Jul-96 & 5 & Thur-Fri & 257900 & 1.5 & 1.5 & \\
\hline OF 169 & 1 & 26-Feb-96 & 1 & Sun-Mon & 209400 & 1.6 & 1.3 & \\
\hline OF 169 & 1 & 27-Feb-96 & 2 & Mon-Tues & 219810 & 1.9 & 1.6 & \\
\hline OF 169 & 1 & 28-Feb-96 & 3 & Tues-Wed & 347260 & 40.0 & 52.6 & Rainfall (0.48 inches) \\
\hline OF 169 & 1 & 29-Feb-96 & 4 & Wed-Thur & 350240 & 2.2 & 2.9 & \\
\hline OF 169 & 1 & 01-Mar-96 & 5 & Thur-Fri & 354460 & 2.9 & 3.9 & \\
\hline OF 169 & 1 & 01-Mar-96 & 5 dup. & Thur-Fri & 354460 & 3.2 & 4.3 & \\
\hline OF 169 & 2 & 29-Apr-96 & 1 & Sun-Mon & 211400 & 2.5 & 2.0 & \\
\hline OF 169 & 2 & 30-Apr-96 & 2 & Mon-Tues & 333230 & 2.4 & 3.0 & Rainfall \\
\hline OF 169 & 2 & 01-May-96 & 3 & Tues-Wed & 231380 & 2.8 & 2.5 & \\
\hline OF 169 & 2 & 02-May-96 & 4 & Wed-Thur & 217070 & 2.5 & 2.1 & \\
\hline OF 169 & 2 & 03-May-96 & 5 & Thur-Fri & 211980 & 2.6 & 2.1 & \\
\hline OF 169 & 3 & 15-Jul-96 & 1 & Sun-Mon & 386320 & 1.0 & 1.5 & Flow s low? \\
\hline OF 169 & 3 & 16-Jul-96 & 2 & Mon-Tues & 304600 & 0.9 & 1.0 & Flow $s$ low?? \\
\hline OF 169 & 3 & 17-Jul-96 & 3 & Tues-Wed & 176020 & 3.4 & 2.3 & \\
\hline OF 169 & 3 & 18-Jul-96 & 4 & Wed-Thur & 200450 & 2.2 & 1.7 & \\
\hline OF 169 & 3 & 19-Jul-96 & 5 & Thur-Fri & 209280 & 2.3 & 1.8 & \\
\hline
\end{tabular}


Table B.1. (cont.)

\begin{tabular}{|c|c|c|c|c|c|c|c|c|}
\hline $\begin{array}{l}\text { Sampling } \\
\text { Location }\end{array}$ & Quarter & $\begin{array}{c}\text { Date } \\
\text { Removed }\end{array}$ & Day & Day of Week & Total Flow & $\mathbf{H g}$ & Hg Loading & COMMENTS \\
\hline & & & & 8:00 - 8:00 & (gal/day) & $(\mu \mathrm{g} / \mathrm{L})$ & (g/day) & \\
\hline E3250N & 3 & 15-Jul-96 & 1 & Sun-Mon & 19530 & 160 & 11.8 & North drain pipe entering \\
\hline E3250N & 3 & 16-Jul-96 & 2 & Mon-Tues & 15210 & 81 & 4.7 & E3250 catch basin \\
\hline E3250N & 3 & 16-Jul-96 & 2 dup. & Mon-Tues & 15210 & 100 & 5.8 & field duplicate \\
\hline E3250N & 3 & 17-Jul-96 & 3 & Tues-Wed & 8180 & 73 & 2.3 & \\
\hline E3250N & 3 & 18-Jul-96 & 4 & Wed-Thur & 7280 & 60 & 1.7 & \\
\hline E3250N & 3 & 19-Jul-96 & 5 & Thur-Fri & 7400 & 53 & 1.5 & \\
\hline 9422-15 & 1 & 26-Feb-96 & 1 & Sun-Mon & 141520 & 0.3 & 0.16 & \\
\hline 9422-15 & 1 & 26-Feb-96 & 1 dup. & Sun-Mon & 141520 & 0.3 & 0.16 & \\
\hline $9422-15$ & 1 & 27-Feb-96 & 2 & Mon-Tues & 146860 & 0.3 & 0.17 & \\
\hline 9422-15 & 1 & 28-Feb-96 & 3 & Tues-Wed & 196240 & 0.2 & 0.15 & Rainfall \\
\hline 9422-15 & 1 & 29-Feb-96 & 4 & Wed-Thur & 144230 & 0.4 & 0.22 & \\
\hline 9422-15 & 1 & 01-Mar-96 & 5 & Thur-Fri & 142650 & 0.4 & 0.22 & \\
\hline 9422-15 & 2 & 29-Apr-96 & 1 & Sun-Mon & 136000 & 0.3 & 0.15 & \\
\hline 9422-15 & 2 & 30-Apr-96 & 2 & Mon-Tues & 224070 & -0.2 & -0.17 & Rainfall \\
\hline $9422-15$ & 2 & 01-May-96 & 3 & Tues-Wed & 146180 & 0.4 & 0.22 & \\
\hline 9422-15 & 2 & 01-May-96 & 3 dup. & Tues-Wed & 146180 & 0.5 & 0.28 & \\
\hline $9422-15$ & 2 & 02-May-96 & 4 & Wed-Thur & 132960 & 0.3 & 0.15 & \\
\hline 9422-15 & 2 & 03-May-96 & 5 & Thur-Fri & 130340 & 0.3 & 0.15 & \\
\hline $9422-15$ & 3 & 15-Jul-96 & 1 & Sun-Mon & & & & Equipment problems! No \\
\hline 9422-15 & 3 & 16-Jul-96 & 2 & Mon-Tues & 219330 & 0.4 & 0.33 & \\
\hline $9422-15$ & 3 & 17-Jul-96 & 3 & Tues-Wed & 109820 & 0.3 & 0.12 & \\
\hline 9422-15 & 3 & 18-Jul-96 & 4 & Wed-Thur & 105960 & 0.3 & 0.12 & \\
\hline $9422-15$ & 3 & 19-Jul-96 & 5 & Thur-Fri & 105500 & 0.7 & 0.28 & \\
\hline 9422-15 & 3 & 20-Jul-96 & 6 & Fri-Sat & 114020 & 0.3 & 0.13 & \\
\hline
\end{tabular}




\section{APPENDIX C}

Weekly Mercury Results for Outfall 51 During Fiscal Year 1996 

C-3

Table C.1. Weekly Mercury Results for Outfall 51 During Fiscal Year 1996

\begin{tabular}{|c|c|c|c|}
\hline Sample Date & Total Hg & Flag & Sample Type \\
\hline & $(\mu \mathrm{g} / \mathrm{L})$ & & \\
\hline $030 c t 95$ & 6.4 & $\mathbf{N}$ & Routine \\
\hline $100 \mathrm{ct} 95$ & 6.8 & $\mathbf{N}$ & Routine \\
\hline $170 c t 95$ & 5.9 & $\mathrm{~N}$ & Routine \\
\hline $240 \operatorname{ct} 95$ & 6.1 & $\mathrm{~N}$ & Routine \\
\hline 01Nov95 & 5.6 & $\mathrm{~N}$ & Routine \\
\hline 07Nov95 & 6.7 & $\mathrm{~N}$ & Routine \\
\hline 14Nov95 & 3.4 & $\mathrm{~N}$ & Routine \\
\hline 21Nov95 & 3.6 & $\mathbf{N}$ & Routine \\
\hline 28Nov95 & 4.8 & $\mathrm{~N}$ & Routine \\
\hline 05 Dec95 & 4.0 & $\mathrm{~N}$ & Routine \\
\hline $12 \mathrm{Dec} 95$ & 4.1 & $\mathrm{~N}$ & Routine \\
\hline 19Dec95 & 5.9 & $\mathbf{N}$ & Routine \\
\hline 28Dec95 & 2.5 & $\mathrm{~N}$ & Routine \\
\hline 03Jan96 & 2.8 & $\mathrm{~N}$ & Routine \\
\hline 09Jan96 & 4.6 & $\mathbf{N}$ & Routine \\
\hline $17 \operatorname{Jan} 96$ & 4.2 & $\mathrm{~N}$ & Routine \\
\hline $23 \operatorname{Jan} 96$ & 2.4 & $\mathrm{~N}$ & Routine \\
\hline $30 \operatorname{Jan} 96$ & 2.1 & $\mathrm{~N}$ & Routine \\
\hline 07Feb96 & 2.5 & $\mathrm{~N}$ & Routine \\
\hline $13 \mathrm{Feb} 96$ & 2.6 & $\mathrm{~N}$ & Routine \\
\hline $20 \mathrm{Feb} 96$ & 2.9 & $\mathrm{~N}$ & Routine \\
\hline $27 \mathrm{Feb} 96$ & 2.2 & $\mathrm{~N}$ & Routine \\
\hline 05Mar96 & 2.7 & $\mathrm{~N}$ & Routine \\
\hline 12Mar96 & 1.7 & $\mathbf{N}$ & Routine \\
\hline 19Mar96 & 3.1 & $\mathrm{~N}$ & Routine \\
\hline 26Mar96 & 2.3 & $\mathrm{~N}$ & Routine \\
\hline 02Apr96 & 2.0 & $\mathrm{~N}$ & Routine \\
\hline
\end{tabular}


Table C.1. (cont.)

\begin{tabular}{|c|c|c|c|}
\hline Sample Date & Total Hg & Flag & Sample Type \\
\hline & $(\mu \mathrm{g} / \mathrm{L})$ & & \\
\hline 09Apr96 & 2.3 & $\mathrm{~N}$ & Routine \\
\hline 16Apr96 & 2.8 & $\mathrm{~N}$ & Routine \\
\hline 23Apr96 & 2.6 & $\mathbf{N}$ & Routine \\
\hline 01 May96 & 2.4 & $N$ & Routine \\
\hline 07 May96 & 3.4 & $\mathbf{N}$ & Routine \\
\hline 14May96 & 3.5 & $\mathrm{~N}$ & Routine \\
\hline 21 May96 & 3.4 & $\mathrm{~N}$ & Routine \\
\hline 29May96 & 2.5 & $\mathrm{~N}$ & Routine \\
\hline 04Jun96 & 2.6 & $\mathrm{~N}$ & Routine \\
\hline 11 Jun96 & 2.1 & $\mathbf{N}$ & Routine \\
\hline 18Jun96 & 2.1 & $\mathrm{~N}$ & Routine \\
\hline 25Jun96 & 2.4 & $\mathrm{~N}$ & Routine \\
\hline 02Jul96 & 3.0 & $\mathrm{~N}$ & Routine \\
\hline 09Jul96 & 3.9 & $\mathrm{~N}$ & Routine \\
\hline $15 \mathrm{Jul} 96$ & 4.1 & $\mathbf{N}$ & Routine \\
\hline $16 \mathrm{Jul} 96$ & 3.6 & $\mathbf{N}$ & Routine \\
\hline 17Jul96 & 4.1. & $\mathrm{~N}$ & Routine \\
\hline $17 \mathrm{Jul} 96$ & 3.1 & $\mathbf{N}$ & Routine \\
\hline 18Jul96 & 3.2 & $\mathbf{N}$ & Routine \\
\hline 19Jul96 & 3.3 & $\mathrm{~N}$ & Routine \\
\hline 23Jul96 & 4.0 & $\mathrm{~N}$ & Routine \\
\hline 30Jul96 & 4.1 & $\mathrm{~N}$ & Routine \\
\hline 06Aug96 & 2.1 & $\mathrm{~N}$ & Routine \\
\hline 13Aug96 & 2.2 & $\mathrm{~N}$ & Routine \\
\hline 15Aug96 & 2.0 & $\mathrm{~N}$ & Routine \\
\hline 20 Aug96 & 2.2 & $\mathrm{~N}$ & Routine \\
\hline 27 Aug96 & 2.7 & $\mathbf{N}$ & Routine \\
\hline 10Sep96 & 4.5 & $\mathrm{~N}$ & Routine \\
\hline
\end{tabular}




\section{APPENDIX D}

Bi-weekly Mercury Results and Daily Flows for Outfall 55

During Fiscal Year 1996 

D-3

Table D.1. Bi-weekly mercury results and daily flows for Outfall 55 during fiscal year 1996

\begin{tabular}{|c|c|c|c|c|}
\hline Date & Flow & Total Hg & Flag & Sample Type \\
\hline & (gal/day) & $(\mu \mathrm{g} / \mathrm{L})$ & & \\
\hline $010 c t 95$ & 74562 & & & \\
\hline $020 \mathrm{ct} 95$ & 76821 & & & \\
\hline $030 c t 95$ & 84081 & $<0.2$ & $\mathbf{N}$ & Routine \\
\hline $040 \mathrm{ct} 95$ & 87962 & $<0.2$ & $\mathrm{~N}$ & Routine \\
\hline $050 \mathrm{ct} 95$ & 130001 & & & \\
\hline $060 \mathrm{ct} 95$ & 86011 & & & \\
\hline $070 c t 95$ & 73571 & & & \\
\hline 08 Oct95 & 65447 & & & \\
\hline $090 \mathrm{ct} 95$ & 63635 & & & \\
\hline $100 c t 95$ & 65246 & $<0.2$ & $\mathrm{~N}$ & Routine \\
\hline $110 \mathrm{ct} 95$ & 65152 & $<0.2$ & $\mathrm{~N}$ & Routine \\
\hline $120 \mathrm{ct} 95$ & 62532 & & & \\
\hline 13 Oct95 & 67590 & & & \\
\hline $140 c t 95$ & 67326 & & & \\
\hline $150 c t 95$ & 57652 & & & \\
\hline $160 \mathrm{ct} 95$ & 61623 & $\cdot$ & & \\
\hline $170 \mathrm{ct} 95$ & 63761 & $<0.2$ & $\mathbf{N}$ & Routine \\
\hline $180 \mathrm{ct} 95$ & 65398 & $<0.2$ & $\mathbf{N}$ & Routine \\
\hline $190 \mathrm{ct} 95$ & 63876 & & & \\
\hline $200 \mathrm{ct} 95$ & 66137 & & & \\
\hline $210 c t 95$ & 58733 & & & \\
\hline $220 c t 95$ & 58014 & & & \\
\hline $230 \mathrm{ct} 95$ & 58311 & & & \\
\hline $240 c t 95$ & 63072 & $<0.2$ & $\mathbf{N}$ & Routine \\
\hline $250 c t 95$ & 60369 & $<0.2$ & $\mathrm{~N}$ & Routine \\
\hline $260 c t 95$ & 62127 & & & \\
\hline $270 \mathrm{ct} 95$ & 105924 & & & \\
\hline $280 c t 95$ & 74002 & & & \\
\hline 290ct95 & 65938 & & & \\
\hline $300 c t 95$ & 68772 & & & \\
\hline 31 Oct 95 & 68996 & $<0.2$ & $\mathrm{~N}$ & Routine \\
\hline
\end{tabular}


Table D.1. (cont.)

\begin{tabular}{|c|c|c|c|c|}
\hline Date & Flow & Total Hg & Flag & Sample Type \\
\hline & (gaV/day) & $(\mu \mathrm{g} / \mathrm{L})$ & & \\
\hline 01Nov95 & 82701 & $<0.2$ & $\mathrm{~N}$ & Routine \\
\hline 02Nov95 & 103358 & & & \\
\hline 03 Nov95 & 90726 & & & \\
\hline 04 Nov95 & 68995 & & & \\
\hline 05Nov95 & 64055 & & & \\
\hline 06Nov95 & 78861 & & & \\
\hline 07Nov95 & 124887 & $<0.2$ & $\mathbf{N}$ & Routine \\
\hline 08Nov95 & 72096 & $<0.2$ & $\mathrm{~N}$ & Routine \\
\hline 09Nov95 & 68556 & & & \\
\hline 10Nov95 & 77928 & & & \\
\hline 11 Nov95 & 107248 & & & \\
\hline 12 Nov95 & 73305 & & & \\
\hline 13Nov95 & 69000 & & & \\
\hline 14Nov95 & 70770 & $<0.2$ & $\mathrm{~N}$ & Routine \\
\hline 15 Nov95 & 69519 & $<0.2$ & $\mathbf{N}$ & Routine \\
\hline 16 Nov95 & 64797 & & & \\
\hline 17Nov95 & 62063 & & & \\
\hline 18 Nov95 & 59570 & & & \\
\hline 19Nov95 & 58725 & & & \\
\hline 20 Nov95 & 62544 & $<0.2$ & $\mathrm{~N}$ & Routine \\
\hline 21Nov95 & 56320 & $<0.2$ & $\mathrm{~N}$ & Routine \\
\hline 22Nov95 & 58862 & & & \\
\hline 23Nov95 & 58409 & & & \\
\hline 24Nov95 & 57850 & & & \\
\hline 25 Nov95 & 56737 & & & \\
\hline 26 Nov95 & 56598 & & & \\
\hline 27Nov95 & 62321 & & & \\
\hline 28Nov95 & 64361 & $<0.2$ & $\mathrm{~N}$ & Routine \\
\hline 29Nov95 & 93786 & $<0.2$ & $\mathrm{~N}$ & Routine \\
\hline 30 Nov95 & 69011 & & & \\
\hline
\end{tabular}


D-5

Table D.1. (cont.)

\begin{tabular}{|c|c|c|c|c|}
\hline Date & Flow & Total Hg & Flag & Sample Type \\
\hline & (gal/day) & $(\mu \mathrm{g} / \mathrm{L})$ & & \\
\hline $01 D e c 95$ & 64588 & & & \\
\hline 02Dec95 & 59982 & & & \\
\hline 03Dec95 & 62900 & & & \\
\hline 04Dec95 & 61800 & & & \\
\hline 05Dec95 & 60005 & $<0.2$ & $\mathrm{~N}$ & Routine \\
\hline 06Dec95 & 63151 & $<0.2$ & $\mathrm{~N}$ & Routine \\
\hline 07Dec95 & 66918 & & & \\
\hline 08Dec95 & 68610 & & & \\
\hline 09Dec95 & 71342 & & & \\
\hline 10Dec95 & 66286 & & & \\
\hline 11 Dec95 & 65590 & & & \\
\hline 12Dec95 & 67169 & $<0.2$ & $\mathrm{~N}$ & Routine \\
\hline 13Dec95 & 65330 & $<0.2$ & $\mathrm{~N}$ & Routine \\
\hline 14Dec95 & 66587 & & & \\
\hline 15Dec95 & 67490 & & & \\
\hline 16Dec95 & 59246 & & & \\
\hline 17Dec95 & 59840 & & & \\
\hline $18 \mathrm{Dec} 95$ & 85424 & $<0.2$ & $\mathrm{~N}$ & Routine \\
\hline 19Dec95 & 124975 & $<0.2$ & $\mathrm{~N}$ & Routine \\
\hline 20Dec95 & 79411 & & & \\
\hline 21Dec95 & 71592 & & & \\
\hline 22Dec95 & 69079 & & & \\
\hline 23Dec95 & 68440 & & & \\
\hline 24Dec95 & 67916 & & & \\
\hline 25Dec95 & 67479 & & & \\
\hline 26Dec95 & 67046 & & & \\
\hline 27Dec95 & 67148 & & & \\
\hline $28 \mathrm{Dec} 95$ & 66605 & $<0.2$ & $\mathbf{N}$ & Routine \\
\hline 29Dec95 & 64663 & $<0.2$ & $\mathrm{~N}$ & Routine \\
\hline 30Dec95 & 63654 & & & \\
\hline $31 \mathrm{Dec} 95$ & 61328 & & & \\
\hline
\end{tabular}




\section{D-6}

Table D.1. (cont)

\begin{tabular}{|c|c|c|c|c|}
\hline Date & Flow & Total $\mathbf{~ H g}$ & Flag & Sample Type \\
\hline & (gaV/day) & $(\mu \mathrm{g} / \mathrm{L})$ & & \\
\hline $01 \operatorname{Jan} 96$ & 60188 & & & \\
\hline 02Jan 96 & 87942 & & & \\
\hline 03Jan96 & 68793 & & & \\
\hline 04Jan96 & 67970 & $<0.2$ & $\mathrm{~N}$ & Routine \\
\hline $05 \operatorname{Jan} 96$ & 63542 & $<0.2$ & $\mathrm{~N}$ & Routine \\
\hline 06Jan96 & 100173 & & & \\
\hline 07Jan96 & 79832 & & & \\
\hline $08 \operatorname{Jan} 96$ & 70424 & & & \\
\hline $09 \operatorname{Jan} 96$ & 69179 & $<0.2$ & $\mathrm{~N}$ & Routine \\
\hline $10 \operatorname{Jan} 96$ & 67110 & $\leq 0.2$ & $\mathrm{~N}$ & Routine \\
\hline $11 \operatorname{Jan} 96$ & 59016 & & & \\
\hline $12 \operatorname{Jan} 96$ & 73126 & & & \\
\hline 13Jan 96 & 65665 & & & \\
\hline 14Jan96 & 61016 & & & \\
\hline $15 \operatorname{Jan} 96$ & 60392 & & & \\
\hline 16Jan96 & 52201 & & & \\
\hline $17 \mathrm{Jan} 96$ & 59283 & $<0.2$ & $\mathbf{N}$ & Routine \\
\hline $18 \operatorname{Jan} 96$ & 84438 & $<0.2$ & $\mathrm{~N}$ & Routine \\
\hline 19Jan96 & 73015 & & & \\
\hline $20 \operatorname{Jan} 96$ & 64345 & & & \\
\hline 21Jan 96 & 59429 & & & \\
\hline 22Jan96 & 57937 & & & \\
\hline 23Jan96 & 55275 & $<0.2$ & $\mathrm{~N}$ & Routine \\
\hline 24Jan 96 & 73947 & $<0.2$ & $\mathrm{~N}$ & Routine \\
\hline $25 \operatorname{Jan} 96$ & 61657 & & & \\
\hline 26Jan96 & 86934 & & . & \\
\hline 27Jan96 & 79096 & & & \\
\hline $28 \operatorname{Jan} 96$ & 69633 & & & \\
\hline 29Jan96 & 67367 & & & \\
\hline 30Jan96 & 65432 & $<0.2$ & $\mathbf{N}$ & Routine \\
\hline $31 \operatorname{Jan} 96$ & 59687 & $<0.2$ & $\mathbf{N}$ & Routine \\
\hline
\end{tabular}


D-7

Table D.1. (cont.)

\begin{tabular}{|c|c|c|c|c|}
\hline Date & Flow & Total Hg & Flag & Sample Type \\
\hline & (gal/day) & $(\mu \mathrm{g} / \mathrm{L})$ & & \\
\hline $01 \mathrm{Feb} 96$ & 59766 & & & \\
\hline 02Feb96 & 61083 & & & \\
\hline 03Feb96 & 64716 & & & \\
\hline 04Feb96 & 64401 & & & \\
\hline 05Feb96 & 61349 & & & \\
\hline 06Feb96 & 58927 & & & \\
\hline 07Feb96 & 59687 & $<0.2$ & $\mathrm{~N}$ & Routine \\
\hline 08Feb96 & 83906 & $<0.2$ & $\mathrm{~N}$ & Routine \\
\hline 09Feb96 & 83405 & & & \\
\hline 10 Feb96 & 78434 & & & \\
\hline 11 Feb96 & 73114 & & & \\
\hline 12 Feb 96 & 71333 & & & \\
\hline 13 Feb96 & 70851 & & & \\
\hline $14 \mathrm{Feb} 96$ & 65666 & $<0.2$ & $\mathrm{~N}$ & Routine \\
\hline 15 Feb96 & 61342 & $<0.2$ & $\mathbf{N}$ & Routine \\
\hline 16 Feb 96 & 60428 & & & \\
\hline $17 \mathrm{Feb} 96$ & 59289 & & & \\
\hline $18 \mathrm{Feb} 96$ & 57588 & & & \\
\hline 19 Feb96 & 58941 & & & \\
\hline $20 \mathrm{Feb} 96$ & 77459 & $<0.2$ & $\mathbf{N}$ & Routine \\
\hline 21Feb96 & 69211 & $<0.2$ & $\mathbf{N}$ & Routine \\
\hline 22Feb96 & 67888 & & & \\
\hline 23Feb96 & 66777 & & & \\
\hline 24Feb96 & 59252 & & & \\
\hline $25 \mathrm{Feb} 96$ & 58755 & & & \\
\hline 26Feb96 & 60864 & & & \\
\hline 27Feb96 & 60494 & $<0.2$ & $\mathrm{~N}$ & Routine \\
\hline $28 \mathrm{Feb} 96$ & 65325 & $<0.2$ & $\mathbf{N}$ & Routine \\
\hline 29Feb96 & 57445 & & & \\
\hline
\end{tabular}


D-8

Table D.1. (cont.)

\begin{tabular}{|c|c|c|c|c|}
\hline Date & Flow & Total Hg & Flag & Sample Type \\
\hline & (gal/day) & $(\mu \mathrm{g} / \mathrm{L})$ & & \\
\hline $01 \mathrm{Mar} 96$ & 21803 & & & \\
\hline $02 \mathrm{Mar} 96$ & 21664 & & & \\
\hline 03Mar96 & 21515 & & & \\
\hline 04Mar96 & 20746 & & & \\
\hline 05Mar96 & 21949 & $<0.2$ & $\mathbf{N}$ & Routine \\
\hline $06 \mathrm{Mar} 96$ & 36724 & $<0.2$ & $\mathbf{N}$ & Routine \\
\hline $07 \mathrm{Mar} 96$ & 48602 & & & \\
\hline 08Mar96 & 26780 & & & \\
\hline 09Mar96 & 24771 & & & \\
\hline 10Mar96 & 23919 & & & \\
\hline $11 \mathrm{Mar} 96$ & 23846 & & & \\
\hline 12Mar96 & 23527 & $<0.2$ & $\mathbf{N}$ & Routine \\
\hline $13 \mathrm{Mar} 96$ & 22736 & $<0.2$ & $\mathbf{N}$ & Routine \\
\hline 14Mar96 & 63768 & & & \\
\hline $15 \mathrm{Mar} 96$ & 63464 & & & \\
\hline 16Mar96 & 70259 & & & \\
\hline $17 \mathrm{Mar} 96$ & 70236 & & & \\
\hline $18 \mathrm{Mar} 96$ & 66703 & & & \\
\hline 19Mar96 & 72951 & 0.2 & $\mathrm{~N}$ & Routine \\
\hline 20Mar96 & 72360 & $<0.2$ & $N$ & Routine \\
\hline $21 \mathrm{Mar} 96$ & 61677 & & & \\
\hline 22Mar96 & 69334 & & & \\
\hline 23Mar96 & 62249 & & & \\
\hline 24Mar96 & 61367 & & & \\
\hline 25Mar96 & 61180 & & & \\
\hline $26 \mathrm{Mar} 96$ & 66794 & $<0.2$ & $\mathbf{N}$ & Routine \\
\hline 27Mar96 & 62938 & $<0.2$ & $\mathrm{~N}$ & Routine \\
\hline 28Mar96 & 68935 & & & \\
\hline 29Mar96 & 91663 & & & \\
\hline $30 \mathrm{Mar} 96$ & 79379 & & & \\
\hline 31Mar96 & 73517 & & & \\
\hline
\end{tabular}


D-9

Table D.1. (cont.)

\begin{tabular}{|c|c|c|c|c|}
\hline Date & Flow & Total Hg & Flag & Sample Type \\
\hline & (gal/day) & $(\mu \mathrm{g} / \mathrm{L})$ & & \\
\hline 01 Apr96 & 82369 & & & \\
\hline 02Apr 96 & 63537 & & & \\
\hline 03Apr96 & 58832 & $<0.2$ & $\mathrm{~N}$ & Routine \\
\hline 04Apr96 & 65356 & $<0.2$ & $\mathrm{~N}$ & Routine \\
\hline 05Apr96 & 83486 & & & \\
\hline 06Apr96 & 78802 & & & \\
\hline 07Apr96 & 65400 & & & \\
\hline 08Apr96 & 64944 & & & \\
\hline 09Apr96 & 66624 & $<0.2$ & $\mathrm{~N}$ & Routine \\
\hline 10Apr96 & 14348 & $<0.2$ & $\mathrm{~N}$ & Routine \\
\hline 11Apr96 & 56276 & & & \\
\hline 12Apr96 & 60640 & & & \\
\hline 13Apr96 & 79214 & & & \\
\hline 14Apr96 & 68324 & & & \\
\hline 15Apr 96 & 72380 & - & & \\
\hline 16Apr96 & 71211 & $<0.2$ & $\mathrm{~N}$ & Routine \\
\hline 17Apr96 & 73947 & $<0.2$ & $\mathrm{~N}$ & Routine \\
\hline 18Apr96 & 69405 & & & \\
\hline 19Apr96 & 71704 & & & \\
\hline 20Apr96 & 72552 & & & \\
\hline 21Apr96 & 78639 & & & \\
\hline 22Apr96 & 95856 & & & \\
\hline 23Apr96 & 82698 & & & \\
\hline 24Apr96 & 79071 & $<0.2$ & $\mathrm{~N}$ & Routine \\
\hline 25Apr96 & 72948 & $<0.2$ & $\mathbf{N}$ & Routine \\
\hline 26Apr96 & 76987 & & & \\
\hline 27Apr96 & 88736 & & & \\
\hline 28Apr96 & 79407 & & & \\
\hline 29Apr96 & 77908 & $<0.2$ & $\mathbf{N}$ & Routine \\
\hline 30 Apr 96 & 79079 & $<0.2$ & $N$ & Routine \\
\hline
\end{tabular}


D-10

Table D.1. (cont.)

\begin{tabular}{|c|c|c|c|c|}
\hline Date & Flow & Total $\mathrm{Hg}$ & Flag & Sample Type \\
\hline & (gal/day) & $(\mu \mathrm{g} / \mathrm{L})$ & & \\
\hline 01 May96 & 96585 & & & \\
\hline 02May96 & 82664 & & & \\
\hline 03May96 & 76994 & & & \\
\hline 04May96 & 73772 & & & \\
\hline 05 May96 & 74166 & & & \\
\hline 06May96 & 75091 & $<0.2$ & $\mathrm{~N}$ & Routine \\
\hline 07May96 & 77722 & $<0.2$ & $\mathrm{~N}$ & Routine \\
\hline $08 \mathrm{May} 96$ & 89683 & & & \\
\hline 09May96 & 76422 & & & \\
\hline 10May96 & 76427 & & & \\
\hline 11 May96 & 80764 & & & \\
\hline 12 May96 & 74732 & & & \\
\hline 13 May96 & 68382 & $<0.2$ & $\mathrm{~N}$ & Routine \\
\hline 14May96 & 64037 & $<0.2$ & $\mathrm{~N}$ & Routine \\
\hline 15 May96 & 60202 & & & \\
\hline 16May96 & 89983 & & & \\
\hline 17 May96 & 64110 & & & \\
\hline 18 May96 & 66663 & & & \\
\hline 19May96 & 77139 & & & \\
\hline 20May96 & 79304 & $<0.2$ & $\mathrm{~N}$ & Routine \\
\hline 21May96 & 80880 & $<0.2$ & $\mathbf{N}$ & Routine \\
\hline 22May96 & 80689 & & & \\
\hline 23May96 & 75980 & & & \\
\hline 24May96 & 73748 & & & \\
\hline 25 May96 & 80569 & & & \\
\hline 26May96 & 95122 & & & \\
\hline 27May96 & 79436 & & & \\
\hline 28May96 & 94247 & $<0.2$ & $\mathbf{N}$ & Routine \\
\hline 29May96 & 106539 & $<0.2$ & $\mathrm{~N}$ & Routine \\
\hline 30Мау96 & 78449 & & & \\
\hline 31 May96 & 72381 & & & \\
\hline
\end{tabular}


D-11

Table D.1. (cont.)

\begin{tabular}{|c|c|c|c|c|}
\hline Date & Flow & Total Hg & Flag & Sample Type \\
\hline & (gal/day) & $(\mu \mathrm{g} / \mathrm{L})$ & & \\
\hline 01Jun96 & 69779 & & & \\
\hline 02Jun96 & 67635 & & & \\
\hline 03Jun96 & 66943 & $<0.2$ & $\mathrm{~N}$ & Routine \\
\hline 04Jun96 & 66027 & $<0.2$ & $\mathrm{~N}$ & Routine \\
\hline 05Jun96 & 63437 & & & \\
\hline 06Jun96 & 63942 & & & \\
\hline 07Jun96 & 63231 & & & \\
\hline 08Jun96 & 65889 & & & \\
\hline 09Jun96 & 68058 & & & \\
\hline 10Jun96 & 136480 & $<0.2$ & $\mathbf{N}$ & Routine \\
\hline 11Jun96 & 69068 & $<0.2$ & $\mathbf{N}$ & Routine \\
\hline 12Jun96 & 63054 & & & \\
\hline 13Jun96 & 65744 & & & \\
\hline 14Jun96 & 87994 & & & \\
\hline 15Jun96 & 67480 & & & \\
\hline 16Jun96 & 65742 & & & \\
\hline 17Jun96 & 64536 & t & & \\
\hline 18Jun96 & 66031 & $<0.2$ & $\mathrm{~N}$ & Routine \\
\hline 19Jun96 & 71436 & & & \\
\hline 20 Jun 96 & 78200 & $<0.2$ & $\mathbf{N}$ & Routine \\
\hline 21 Jun96 & 76832 & & & \\
\hline 22Jun96 & 74635 & & & \\
\hline 23Jun96 & 67209 & & & \\
\hline 24Jun96 & 66285 & $<0.2$ & $\mathbf{N}$ & Routine \\
\hline 25Jun96 & 68363 & $<0.2$ & $\mathrm{~N}$ & Routine \\
\hline 26Jun96 & 75488 & & & \\
\hline 27Jun96 & 66389 & & & \\
\hline 28Jun96 & 69812 & & & \\
\hline 29Jun96 & 67970 & & & \\
\hline 30 Jun96 & 66874 & & & \\
\hline
\end{tabular}


D-12

Table D.1. (cont)

\begin{tabular}{|c|c|c|c|c|}
\hline Date & Flow & Total Hg & Flag & Sample Type \\
\hline & (gal/day) & $(\mu \mathrm{g} / \mathrm{L})$ & & \\
\hline 01Jul96 & 69081 & & & \\
\hline 02Jul96 & 72447 & $<0.2$ & $\mathbf{N}$ & Routine \\
\hline 03Jul96 & 74206 & $<0.2$ & $\mathrm{~N}$ & Routine \\
\hline 04Jul96 & 73445 & & & \\
\hline 05Jul96 & 70819 & & & \\
\hline 06Jul96 & 66075 & & & \\
\hline 07Jul96 & 67233 & & & \\
\hline 08Jul96 & 68250 & $<0.2$ & $\mathrm{~N}$ & Routine \\
\hline 09Jul96 & 71074 & $<0.2$ & $\mathrm{~N}$ & Routine \\
\hline 10Jul96 & 73503 & & & \\
\hline $11 \mathrm{Jul96}$ & 70656 & & & \\
\hline 12Jul96 & 66881 & & & \\
\hline 13Jul96 & 67729 & & & \\
\hline 14Jul96 & 69775 & & & \\
\hline $15 \mathrm{Jul} 96$ & 69714 & $<0.2$ & $\mathrm{~N}$ & Routine \\
\hline 16Jul96 & 104103 & $<0.2$ & $\mathrm{~N}$ & Routine \\
\hline 17Jul96 & 78617 & & & \\
\hline 18Jul96 & 68000 & & & \\
\hline $19 J u l 96$ & 72942 & & & \\
\hline 20Jul96 & 70330 & & & \\
\hline $21 \mathrm{Jul} 96$ & 78071 & & & \\
\hline 22Jul96 & 105498 & & & \\
\hline 23Jul96 & 80158 & $<0.2$ & $\mathbf{N}$ & Routine \\
\hline 24Jul96 & 78384 & $<0.2$ & $\mathrm{~N}$ & Routine \\
\hline 25Jul96 & 74623 & & & \\
\hline 26Jul96 & 74727 & & & \\
\hline 27Jul96 & 82407 & & & \\
\hline 28Jul96 & 68593 & & & \\
\hline 29Jul96 & 69281 & $<0.2$ & $\mathbf{N}$ & Routine \\
\hline 30Jul96 & 84628 & $<0.2$ & $\mathbf{N}$ & Routine \\
\hline 31 Jul96 & 80840 & & & \\
\hline
\end{tabular}


D-13

Table D.1. (cont.)

\begin{tabular}{|c|c|c|c|c|}
\hline Date & Flow & Total Hg & Flag & Sample Type \\
\hline & (gal/day) & $(\mu \mathrm{g} / \mathrm{L})$ & & \\
\hline 01Aug96 & 105599 & & & \\
\hline 02Aug96 & 126562 & & & \\
\hline 03Aug96 & 62669 & & & \\
\hline 04Aug96 & 60637 & & & \\
\hline 05Aug96 & 62377 & & & \\
\hline 06Aug96 & 66155 & $<0.2$ & $\mathrm{~N}$ & Routine \\
\hline 07Aug96 & 71264 & $<0.2$ & $\mathrm{~N}$ & Routine \\
\hline 08Aug96 & 73528 & & & \\
\hline 09Aug96 & 75760 & & & \\
\hline 10Aug96 & 74954 & & & \\
\hline 11 Aug96 & 68240 & & & \\
\hline 12Aug96 & 67017 & & & \\
\hline 13Aug96 & 108166 & $<0.2$ & $\mathrm{~N}$ & Routine \\
\hline 14Aug96 & 67937 & $<0.2$ & $\mathrm{~N}$ & Routine \\
\hline 15Aug96 & 61920 & 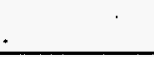 & & \\
\hline 16Aug96 & 60521 & & & \\
\hline 17Aug96 & 58156 & & & \\
\hline 18Aug96 & 60017 & & & \\
\hline 19Aug96 & 58341 & & & \\
\hline 20Aug96 & 58205 & $<0.2$ & $\mathrm{~N}$ & Routine \\
\hline 21 Aug96 & 59996 & $<0.2$ & $\mathbf{N}$ & Routine \\
\hline 22Aug96 & 60495 & & & \\
\hline 23Aug96 & 64012 & & & \\
\hline 24Aug96 & 61628 & & & \\
\hline 25Aug96 & 65670 & $<0.2$ & $\mathrm{~N}$ & Routine \\
\hline 26Aug96 & 64883 & $<0.2$ & $\mathbf{N}$ & Routine \\
\hline 27Aug96 & 62201 & & & \\
\hline 28Aug96 & 60510 & & & \\
\hline 29Aug96 & 59473 & & & \\
\hline 30Aug96 & 63868 & & & \\
\hline 31 Aug96 & 61892 & & & \\
\hline
\end{tabular}




\section{DISTRIBUTION}

1. L. V. Asplund

2. M. O. Barnett

3. M. A. Bogle

4. W. D. Brickeen

5. V. J. Brumback

6. E. T. Collins

7. K.W. Cook

8. K. N. Fischer

9. J. F. Hensley

10. C. C. Hill

11-22. J. A. Johnston

23. D. M. Matteo

24. B. D. Nourse

25. P. T. Owen

26. C. A. Provost

27. G. R. Southworth

28. B. Tschantz

29. R. R. Turner

30-35. L. O. Vaughan

36. R. C. Woods

37. ER Document Management Center-RC

38. M. K. Leslie, CDM Federal Programs, 800 Oak Ridge Turnpike, Oak Ridge, TN 37830 